SIMONE BERNARDINO

\author{
CARACTERIZAÇÃO DOS MECANISMOS IMUNOLÓGICOS \\ ASSOCIADOS COM OS EFEITOS PROTETORES E DELETÉRIOS DO \\ ÓXIDO NÍTRICO NA PARACOCCIDIOIDOMICOSE PULMONAR
}

Tese apresentada ao Instituto de Ciências Biomédicas da Universidade de São Paulo, para obtenção do Título de Doutor em Ciências (Imunologia).

São Paulo 


\section{CARACTERIZAÇÃO DOS MECANISMOS IMUNOLÓGICOS ASSOCIADOS COM OS EFEITOS PROTETORES E DELETÉRIOS DO ÓXIDO NÍTRICO NA PARACOCCIDIOIDOMICOSE PULMONAR}

Tese apresentada ao Instituto de Ciências Biomédicas da Universidade de São Paulo, para obtenção do Título de Doutor em Ciências (Imunologia).

Área de concentração: Imunologia Orientador(a):

Profa. Dra. Vera Lúcia Calich

São Paulo

2009 
DADOS DE CATALOGAÇÃO NA PUBLICAÇÃO (CIP)

Serviço de Biblioteca e Informação Biomédica do

Instituto de Ciências Biomédicas da Universidade de São Paulo

(C) reprodução total

\section{Bernardino, Simone.}

Caracterização dos mecanismos imunológicos associados com os efeitos protetores e deletérios do óxido nítrico na paracoccidioidomicose pulmonar / Simone Bernardino. -- São Paulo, 2009.

\section{Orientador: Vera Lucia Garcia Calich.}

Tese (Doutorado) - Universidade de São Paulo. Instituto de Ciências Biomédicas. Departamento de Imunologia. Área de concentração: Imunologia. Linha de pesquisa: Imunologia das micoses.

Versão do título para o inglês: Characterization of the immunological mechanisms associated with the protective and deleterious effects of nitric oxide in pulmonary paracoccidioidomycosis.

Descritores: 1. Paracoccidioidomicose 2. Óxido nítrico 3. Linfócitos 4. Macrófagos 5. Citocinas 6. Granuloma I. Calich, Vera Lucia Garcia II. Universidade de São Paulo. Instituto de Ciências Biomédicas. Programa de Pós-Graduação em Imunologia III. Título. 


\section{UNIVERSIDADE DE SÃO PAULO \\ INSTITUTO DE CIÊNCIAS BIOMÉDICAS}

Candidato(a):

Simone Bernardino.

Título da Tese:

Caracterização dos mecanismos imunológicos associados com os efeitos protetores e deletérios do óxido nítrico na paracoccidioidomicose pulmonar .

Orientador(a): $\quad$ Vera Lucia Garcia Calich.

A Comissão Julgadora dos trabalhos de Defesa da Tese de Doutorado, em sessão pública realizada a I.................., considerou

\section{( ) Aprovado(a) ( ) Reprovado(a)}

\begin{tabular}{|c|c|}
\hline Examinador(a): & $\begin{array}{l}\text { Assinatura: } \\
\text { Nome: ........ } \\
\text { Instituição: }\end{array}$ \\
\hline Examinador(a): & $\begin{array}{l}\text { Assinatura: } \\
\text { Nome: ........ } \\
\text { Instituição: }\end{array}$ \\
\hline Examinador(a): & $\begin{array}{l}\text { Assinatura: } \\
\text { Nome: ........ } \\
\text { Instituição: . }\end{array}$ \\
\hline Examinador(a): & $\begin{array}{l}\text { Assinatura: } \\
\text { Nome: ........ } \\
\text { Instituição: }\end{array}$ \\
\hline Presidente: & $\begin{array}{l}\text { Assinatura: } \\
\text { Nome: ........ } \\
\text { Instituição: }\end{array}$ \\
\hline
\end{tabular}




\section{Certificado}

Certificamos que o protocolo registrado sob $n^{\circ} \mathbf{7 6}$ nas fls. 7 do livro 2 para uso de animais em experimentação, sob a responsabilidade da Profa. Dra. Vera Lúcia Garcia Calich, Coordenadora da Linha de Pesquisa "Paracoccidioidomicose pulmonar. Fatores do fungo e do hospedetro que influenciam a resposta imune e a gravidade da doença" do qual participou(aram) o(s) aluno(s): Adriana Pina,Laura Raquel Rios Ribeiro e Simone Bernardino está de acordo com os Principios Éticos de Experimentação Animal adotado pelo Colégio Brasileiro de Experimentação Animal (COBEA) e foi aprovado pela COMISSÃO DE ÉTICA EM EXPERMENTAÇĀO ANIMAL (CEEA) em 23.11.2004.

São Paulo, 24 de novembro de 2004.

Profa. Dra. Marilia C. Leite Seeiaender Coordenadora da CEEA

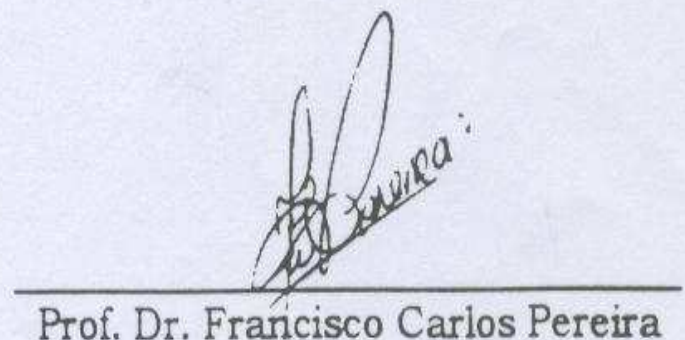

Secretário da CEEA 


\section{AGRADECIMENTOS}

A Deus por me conceder sabedoria, luz e paciência;

Aos meus pais Fátima Beatriz Bernardino e Eduardo Bernardino Filho, pelo amor, dedicação e apoio em todos os momentos desta caminhada que estive longe de vocês. Obrigada por acreditarem em mim. Amo muito vocês;

À minha querida orientadora Dra Vera Lúcia Garcia Calich com quem aprendi a ter paixão por ciência. Uma pessoa extremamente brilhante, dedicada, amiga e companheira. Obrigada pelos ensinamentos em imunologia que me fizeram ser a profissional que hoje sou. Obrigada por confiar e acreditar em mim;

À minha querida amiga Dra. Adriana Pina, com quem convivi durante os anos de mestrado e doutorado. Trabalhamos, rimos e choramos juntas. Tivemos uma grande convivência que nos tornou grandes amigas. Obrigada pelos ensinamentos, carinho e conselhos;

À minha querida amiga Maíra Felonato com quem convivi durante o doutorado. Obrigada por sua amizade, carinho e companheirismo;

Aos colegas e companheiros de laboratório Eliseu Frank de Araujo, Claudia Feriotti, Tânia A. Costa, Dra Celina Arruda, Bruno Motta, Flávio V. Loures e Wagner Alves pelo convívio, amizade e experiência profissional;

Ao Prof. Dr Niels C. Olsen, Prof. Dr Claudio Marinho e Profa. Dra Maria Heloisa Blotta pela participação e ricas sugestões apresentadas no exame de qualificação de doutorado;

Ao Prof. Dr Momtchilo Russo, Profa Dra Celidéia C. Vaz e Profa. Dra Eva Burger pela amizade e conselhos;

À Dra Kátia R.M. Leite, do Setor de Patologia do Hospital Sírio Libanês, pela ajuda e paciência na análise cuidadosa do estudo histopatológico durante o mestrado e doutorado;

Ao Dr. Alexandre C. Keller e Juciane A. Castro pela amizade e companheirismo profissional;

Aos professores do Departamento de Imunologia pelos ensinamentos indispensáveis na realização deste doutorado;

Ao Paulo Albe pela elaboração das lâminas para o estudo histopatológico;

À Regina de Luca pela disponibilidade de camundongos para a realização dos experimentos desta tese;

Aos funcionários da secretaria Jotelma Ribeiro, Amarildo Utiama e Amanda Souza;

Aos funcionários do Biotério do ICB IV por proporcionar um melhor trabalho com os animais de experimentação; 
Aos funcionários da Biblioteca SBIB que contribuíram na elaboração, na revisão textual e no apoio e suporte de informática das diretrizes para elaboração desta tese;

À Fundação de Amparo à Pesquisa do Estado de São Paulo, FAPESP, pelo apoio financeiro fundamental para a realização deste doutorado;

E a todos do Departamento de Imunologia, que de alguma forma contribuíram para a realização deste trabalho. 


\section{DAS UTOPIAS}

Se as coisas são inatingíveis...ora! Não é motivo para não querê-las... Que triste os caminhos, se não fora A presença distante das estrelas! (Mário Quintana) 


\section{RESUMO}

BERNARDINO, S. Caracterização dos mecanismos imunológicos associados com os efeitos protetores e deletérios do óxido nítrico na paracoccidioidomicose pulmonar. 2009. 193 f. Tese (Doutorado em Imunologia) - Instituto de Ciências Biomédicas, Universidade de São Paulo, São Paulo, 2009.

A paracoccidioidomicose (PCM) é uma micose sistêmica de evolução aguda, subaguda ou crônica causada pelo fungo dimórfico Paracoccidioides brasiliensis $(\mathrm{Pb})$. $\mathrm{O}$ propósito deste trabalho foi investigar o efeito do óxido nítrico (NO) nas fases aguda e crônica da PCM pulmonar desenvolvida por camundongos da linhagem C57BL/6 deficientes da enzima óxido nítrico sintase-induzida (C57BL/6 iNOS KO) e seu grupo controle C57BL/6. Caracterizamos os principais parâmetros imunológicos da doença desenvolvida pelos camundongos iNOS-deficientes e normais além de caracterizar o efeito da depleção do TNF- $\alpha$ e de linfócitos $\mathrm{TCD}^{+}$na imunidade desenvolvida por ambas as linhagens. Os camundongos foram infectados com 1 milhão de leveduras viáveis do $\mathrm{Pb}$ pela via intratraqueal e sacrificados nas 2, 6, 8 e 10 semanas pós-infecção. Na fase aguda da doença observamos que os animais NO-deficientes apresentaram doença menos grave com menor número de UFC pulmonar, intenso infiltrado inflamatório de linfócitos $\mathrm{TCD}^{+}$e $\mathrm{TCD}^{+}$ativados $\left(\mathrm{TCD}^{+} \mathrm{CD} 69^{+}, \mathrm{TCD}^{+} \mathrm{CD} 25^{+}, \mathrm{TCD}^{+} \mathrm{CD} 69^{+}\right)$e macrófagos ativados expressando moléculas CD40, CD80, CD86, Ia ${ }^{\mathrm{b}}$ nos pulmões, acompanhados de níveis elevados de TNF- $\alpha$ pulmonar que parecem controlar o crescimento fúngico e disseminação do mesmo para órgãos mais distantes. Uma vez neutralizada essa citocina, notamos aumento discreto da carga fúngica nos pulmões, uma polarização de citocinas para o perfil Th2 e ainda intenso afluxo inflamatório pulmonar. Verificamos ainda que a presença de linfócitos $\mathrm{TCD}^{+}$nos pulmões contribuía com o controle da carga fúngica, já que a depleção desses linfócitos levou a doença mais grave e expressiva redução de migração de células T e macrófagos para os pulmões dos animais iNOS KO. O estudo da atividade fungicida de macrófagos alveolares no curso da doença mostrou que as células de animais iNOS deficientes apresentavam atividade fungicida ineficiente frente ao $\mathrm{Pb}$ além de não serem ativáveis por IFN- $\gamma$. Além disso, a deficiência de NO resultou em aumento significativo de peróxido de hidrogênio produzido por macrófagos alveolares. $\mathrm{Na}$ fase crônica do nosso modelo, observamos quadro da doença contrário àquele da fase aguda. Nos animais KO pudemos observar aumento da carga fúngica pulmonar, acompanhada de menor ativação celular de linfócitos $\mathrm{TCD}^{+}$e de macrófagos. Neste momento notamos um 
aumento da frequência de células $\mathrm{T}$ reguladoras, do fenótipo $\mathrm{CD} 4^{+} \mathrm{CD} 25^{+} \mathrm{Foxp} 3^{+}$, que parecem controlar a ativação exacerbada do sistema imune durante a persistência do patógeno. Apesar de maior carga fúngica nos pulmões, as lesões pulmonares mostraram-se organizadas em granulomas bem formados e coalescentes, com intenso infiltrado celular que foi importante para conter o fungo no sítio primário da infecção. Este fato foi associado à ação do TNF- $\alpha$, já que a sua neutralização resultou em desorganização das lesões pulmonares e morte precoce dos animais KO. Além disso, essa neutralização ocasionou uma inflamação intensa nos pulmões dos animais tratados, que esteve associada à menor sobrevida dos camundongos. Em conclusão, através de um único modelo experimental pudemos verificar que o oxido nítrico apresenta papeis distintos em fases diversas da infecção pelo $P$. brasiliensis.

Palavras-chave: Paracoccidioides brasiliensis. Óxido nítrico. Óxido nítrico sintase-induzida. TNF- $\alpha$. Linfócitos. Macrófagos. 


\begin{abstract}
BERNARDINO, S. Characterization of immunological mechanisms associated with the deleterious and protective effects of nitric oxide in pulmonary paracoccidioidomycosis. 2009. 193 p. Thesis (Doctor in Immunology) - Instituto de Ciências Biomédicas, Universidade de São Paulo, São Paulo, 2009.
\end{abstract}

Paracoccidioidomycosis (PCM) is a systemic mycosis with an acute or chronic evolution caused by the dimorphic fungus Paracoccidioides brasiliensis $(\mathrm{Pb})$. The aim of this work was to investigate the role of nitric oxide (NO) in the acute and chronic phases of pulmonary PCM developed by inducible nitric oxide deficient mice (C57BL/6 iNOS KO) and their normal counterparts (C57BL/6). We characterized the main immunological parameters developed by deficient and WT mice and studied the influence of TNF- $\alpha$ and CD8+ T cells in the immunity developed by both mouse strains. The mice were infected by the intratracheal route with 1 million viable yeasts of $\mathrm{Pb}$ and sacrificed 2, 6, 8 and 10 weeks post infection. In the acute phase we observed a less severe disease in NO-deficient mice which develop decreased pulmonary CFU counts, high inflammatory infiltrate of activated $\mathrm{CD} 4^{+}$and $\mathrm{CD} 8^{+} \mathrm{T}$ lymphocytes $\left(\mathrm{CD} 4^{+} \mathrm{CD} 69^{+} \mathrm{T}, \mathrm{CD} 4^{+} \mathrm{CD} 25^{+} \mathrm{T}, \mathrm{CD} 8^{+} \mathrm{CD} 69^{+} \mathrm{T}\right)$ and activated macrophages expressing CD40, CD80, CD86 and $\mathrm{Ia}^{\mathrm{b}}$ molecules, together with increased levels of pulmonary TNF- $\alpha$ that seem to control the fungal growth and its dissemination to others organs. The depletion of TNF- $\alpha$ resulted in moderate increased pulmonary CFU counts in KO mice, a Th2 polarization of cytokines and intense infiltration of inflammatory cells to the lungs. In addition, the depletion of CD8 T cells resulted in more severe infection and decreased migration of T lymphocytes and macrophages to the lungs of iNOS KO but not WT mice. The fungicidal activity of alveolar macrophages obtained at the $2^{\text {nd }}$ and $10^{\text {th }}$ week postinfection showed that iNOS-deficient macrophages presented inefficient fungal killing and were not activated by IFN- $\gamma$. Moreover, alveolar macrophages from NO-deficient mice produced increased levels of hydrogen peroxide. Studies performed at the chronic phase of infection demonstrated an opposite behavior of the disease. The iNOS KO mice showed higher pulmonary fungal loads, with decreased activated $\mathrm{CD}^{+} \mathrm{T}$ cells and less activated macrophages than WT mice. At this moment the frequency of regulatory $\mathrm{CD} 4^{+} \mathrm{CD} 25^{+} \mathrm{Foxp} 3^{+}$ $\mathrm{T}$ cells was higher in the lungs of deficient mice and seems to control the exacerbated imune response due to the increased presence of the $\mathrm{Pb}$. Despite the higher fungal loads in the lungs of $\mathrm{KO}$ mice, the pulmonary histophatology showed a more organized inflammatory reaction 
composed by well-organized granulomas surrounding aggregated yeast cells at the site of infection. This fact was associated with the TNF- $\alpha$ activity since its neutralization resulted in non-organized pulmonary lesions and acute mortality of $\mathrm{KO}$ mice. In addition, a massive inflammatory reaction was observed in the lungs of TNF- $\alpha$-depleted mice and was associated with the higher mortality rates detected. In conclusion, in a single model of infection we could verify that nitric oxide exerts a dual role in different phases of $P$. brasiliensis infection.

Key words: Paracoccidioides brasiliensis. Nitric oxide. Inducible nitric oxide synthase. TNF$\alpha$. Lymphocytes. Macrophages. 


\section{LISTA DE ILUSTRAÇÕES}

Figura 1. Caracterização da gravidade da doença e produção de citocinas por 50 camundongos iNOS KO e WT

Figura 2. Estudo da atividade fungicida in vitro e produção de $\mathrm{H}_{2} \mathrm{O}_{2}$ e $\mathrm{NO}$ de macrófagos alveolares de camundongos iNOS KO e seu grupo controle após 2 semanas de infecção

Figura 3. Estudo da atividade fungicida in vitro e produção de $\mathrm{NO}$ de macrófagos alveolares de camundongos iNOS KO e seu grupo controle após 10 semanas de infecção

Figura 4. Análise fenotípica de linfócitos infiltrantes de pulmão de animais iNOS KO e seu grupo controle WT nas segunda e décima semanas de infecção

Figura 5. Caracterização da presença de células $\mathrm{T}$ reguladoras do fenótipo $\mathrm{T}$ $\mathrm{CD} 4^{+} \mathrm{CD} 25^{+} \mathrm{FoxP} 3^{+}$no pulmão de animais iNOS KO e seu grupo controle WT nas segunda e décima semanas de infecção

Figura 6. Análise fenotípica de macrófagos alveolares de animai iNOS KO e seu grupo controle WT nas segunda e décima semanas de infecção

Figura 6.1 Quantificação de macrófagos $\mathrm{CD} 11 \mathrm{~b}^{\text {high }} \mathrm{CD} 80^{\text {high }}$ e de células dendríticas $\mathrm{CD} 11 \mathrm{c}^{\text {high }} \mathrm{CD} 86^{\text {high }}$ infiltrantes de pulmão de camundongos KO e seu grupo controle WT na segunda semana de infecção

Figura 7. Efeito da depleção in vivo da citocina TNF- $\alpha$ na gravidade da doença

Figura 8. Efeito da depleção in vivo da citocina TNF- $\alpha$ na produção de citocinas pro e anti-inflamatórias pulmonares e hepáticas de animais KO e WT

Figura 9. Efeito da depleção in vivo na citocina TNF- $\alpha$ nas subpopulações de linfócitos infiltrantes de pulmão de camundongos iNOS KO e seu grupo controle WT na segunda semana de infecção

Figura 10. Efeito da depleção in vivo da citocina TNF- $\alpha$ nos macrófagos infiltrantes de pulmão de camundongos iNOS KO e seu grupo WT

Figura 11. Análise histopatológica dos pulmões de animais iNOS KO e seu grupo controle WT tratados com anti-TNF- $\alpha$ na oitava semana de infecção

Figura 12. Efeito da depleção in vivo de linfócitos $\mathrm{T}$ CD8 na carga fúngica pulmonar de camundongos iNOS KO e seu grupo WT

Figura 13. Efeito da depleção in vivo de linfócitos $\mathrm{T}$ CD8 nos linfócitos infiltrantes de pulmão de camundongos iNOS KO e seu grupo WT

Figura 14. Efeito da depleção in vivo de linfócitos T CD8 nos macrófagos 


\section{LISTA DE ABREVIATURAS E SIGLAS}

\begin{tabular}{|c|c|}
\hline AcM & Anticorpo monoclonal \\
\hline Ag & Antígeno \\
\hline Anti-CD4 & Anticorpo anti-CD4 \\
\hline Anti-CD8 & Anticorpo anti-CD8 \\
\hline Anti-CD11b & Anticorpo anti-CD11b \\
\hline Anti-CD11c & Anticorpo anti-CD11c \\
\hline Anti-CD25 & Anticorpo anti-CD25 \\
\hline Anti-CD40 & Anticorpo anti-CD40 \\
\hline Anti-CD69 & Anticorpo anti-CD69 \\
\hline Anti-CD80 & Anticorpo anti-CD80 \\
\hline Anti-CD86 & Anticorpo anti-CD86 \\
\hline Anti-Ia ${ }^{b}$ & Anticorpo anti-Ia ${ }^{\mathrm{b}}$ \\
\hline APC & Célula apresentadora de antígeno \\
\hline BCA & Método do ácido bicinconínico \\
\hline BHI & Infusão de cérebro e coração \\
\hline $\mathbf{C 3 b}$ & Proteína opsonina componente do sistema complemento \\
\hline CCL22 & Quimiocina CCL22 \\
\hline CCL5 & Quimiocina CCL5 \\
\hline CCR4 & Receptor para quimiocina CCL22 \\
\hline CCR5 & Receptor para quimiocina CC5 \\
\hline CD11b & $\begin{array}{l}\text { Marcador de expressão celular para monócitos e células mielóides } \\
\text { ou Mac-1 }\end{array}$ \\
\hline CD11c & $\begin{array}{l}\text { Marcador de expressão celular para monócitos e células mielóides, } \\
\text { ou CR4 }\end{array}$ \\
\hline CD25 & $\begin{array}{l}\text { Marcador de ativação celular em linfócitos, cadeia } \alpha \text { do receptor de } \\
\text { IL-2 }\end{array}$ \\
\hline CD4 & $\begin{array}{l}\text { Marcador para linfócito Th1/Th2, co receptor para molécula MHC } \\
\text { classe II }\end{array}$ \\
\hline CD40 & $\begin{array}{l}\text { Molécula coestimuladora presente em M } \varnothing \text {, DC, linfócito B, liga-se } \\
\text { ao CD } 40 \mathrm{~L}\end{array}$ \\
\hline CD69 & Marcador de ativação celular inicial para linfócitos T e B \\
\hline CD8 & $\begin{array}{l}\text { Marcador para linfócito } \mathrm{T} \text { citotóxico, co receptor para molécula } \\
\text { MHC classe I }\end{array}$ \\
\hline CD80 & $\begin{array}{l}\text { Molécula coestimuladora ou B7.1, presente em monócitos, liga-se } \\
\text { em CD28 e CTLA-4 }\end{array}$ \\
\hline CD86 & $\begin{array}{l}\text { Molécula coestimuladora ou B7.2, presente em monócitos, DC, } \\
\text { liga-se ao CD } 28 \text { e CTLA- } 4\end{array}$ \\
\hline CD8 $\alpha+D C$ & Célula dendrítica linfóide com o marcador CD8 $\alpha$ \\
\hline CD8 $\alpha-D C$ & Célula dendrítica plasmocitóide sem o marcador CD $8 \alpha$ \\
\hline CTLA-4 & "Cytotoxic T lymphocyte-associated antigen" \\
\hline Су & Anticorpo marcado com fluorocromo Cy-Chrome \\
\hline D.O. & Densidade óptica \\
\hline DC & Célula dendrítica \\
\hline DME & “Dulbelcco's modified eagle's medium" - meio para cultura celular \\
\hline E.P. & Erro padrão \\
\hline ELISA & "Enzyme-linked-immunosorbent assay" \\
\hline FA & Forma adulta da paracoccidioidomicose \\
\hline FACS & "Fluorescence-activated cell sorting" \\
\hline FasL & $\begin{array}{l}\text { ou CD95L, CD178, presente em linfócitos T CD4, liga-se ao Fas, } \\
\text { ligação Fas-FasL: apoptose }\end{array}$ \\
\hline FITC & anticorpo marcado com isotiocinado de fluoresceína \\
\hline
\end{tabular}


FJ

Foxp3

FSC

G-CSF

GITR

gld

GM-CSF

gp 43

H\&E

H-35

i.p.

i.t.

$\mathbf{I a}^{\mathrm{b}}$

iC3b

ICAM-1

IDO

IFN- $\gamma$

Ig

IgA

IgE

IgG

IgG 2

IgG 2a

IgG 4

IL-1及

IL-2

IL-4

IL-5

IL-10

IL-12

iNOS

iNOS KO

iNOS $^{-1-}$

KO

KO anti-CD8

KO anti-TNF- $\alpha$

KO IgG

LBA

LMNA

L-NAME

L-NMMA

LPS

MCP-1

MHC II

MIP-1a

МØ

MP6-XT22

MR

MyD88

NFKB

$\mathbf{N}^{\mathrm{G}}$-MMLA

NK

NOS I

NOS II

NOS III
Forma Juvenil da paracoccidioidomicose

"Forkhead family of transcriptional regulator Foxp3"

"foward scatter", tamanho celular

"Granulocyte colony-stimulating factor"

"Glucocorticoid-induced tumor necrosis factor receptor"

"generalizated lymphoproliferative disorder"

"Granulocyte-monocyte colony-stimulating factor"

Glicoproteína de 43 kilodalton

Hematoxilina e Eosina

Hibridoma rat IgG 1 anti-CD8

Intraperitoneal

Intratraqueal

Marcador para expressão de MHC classe II em monócitos

Fragmento protéico integrante do sistema complemento

"Intercellular adhesion molecule-1"

"indoleamine 2,3-dioxygenase"

Interferon- $\gamma$

Imunoglobulina

Imunoglobulina A

Imunoglobulina isótipo $\mathrm{E}$

Imunoglobulina isótipo $\mathrm{G}$

Imunoglobulina isótipo 2

Imunoglobulina isótipo 2a

Imunoglobulina isótipo 4

Interleucina $1 \beta$

Interleucina 2

Interleucina 4

Interleucina 5

Interleucina 10

Interleucina 12

Óxido nítrico sintase induzida

Óxido nítrico sintase induzida "knockout"

Óxido nítrico sintase induzida deficiente ou "knockout"

"Knockout"ou deficiente

Animal iNOS KO tratado com anticorpo anti-linfócito T CD8

Animal iNOS KO tratado com anticorpo anti-TNF- $\alpha$

Animal iNOS KO tratado com anticorpo IgG normal de rato

Lavado bronco-alveolar

" $\mathrm{N}^{\mathrm{G}}$-methyl-L-arginine"

" $\mathrm{N}^{\mathrm{G}}$-nitro-L-arginina metil ester"

" $\mathrm{N}^{(\mathrm{G})}$-monomethyl-L-arginine"

Lipossacáride de bactéria GRAM negativa

"Monocyte chemoattractant protein-1"

Complexo principal de histocompatibilidade classe II

"Macrophage inflammatory protein 1- $\alpha$ "

Macrófago

Hibridoma rat IgG1 anti-TNF- $\alpha$

Receptor de manose

Proteína adaptadora MyD88

Fator nuclear $\kappa \mathrm{B}$

" $\mathrm{N}^{\mathrm{G}}$-monomethyl-L-arginine"

"natural killer"

Óxido nítrico sintase neural

Óxido nítrico sintase induzida

Óxido nítrico sintase endotelial 


\begin{tabular}{|c|c|}
\hline OPD & ortofenilenodiamina \\
\hline OVA & Ovalbumina \\
\hline P. brasiliensis & Paracoccidioides brasiliensis \\
\hline PAMP & "Pathogen-associated molecular patterns" \\
\hline $\mathbf{P b}$ & Paracoccidioides brasiliensis \\
\hline Pb 18 & Paracoccidioides brasiliensis, isolado 18 \\
\hline PBS & Solução salina em tampão fosfato $0,15 \mathrm{M}, \mathrm{pH} 7,2$ \\
\hline PBS/EDTA & Solução salina em tampão fosfato $0,15 \mathrm{M}, \mathrm{pH} 7,2+$ EDTA \\
\hline PCM & Paracoccidioidomicose \\
\hline PE & Anticorpo marcado com ficoeritrina \\
\hline PMA & "Phorbol 12-myristane 13-acetate"- ativador celular \\
\hline PMN & Neutrófilo polimorfonuclear \\
\hline PRR & "Pattern recognition receptors" \\
\hline RNI & Radicais intermediários de nitrogênio \\
\hline ROI & Radicais intermediários de oxigênio \\
\hline RPMI & Meio para cultura celular, tampão bicarbonato, $\mathrm{pH}$ 6,8 \\
\hline SFB & Soro fetal bovino \\
\hline SOD & Superóxido-dismutase \\
\hline SPF & "Specific pathogen free" \\
\hline SSC & "side scatter", granulosidade celular \\
\hline $\mathrm{T} \mathrm{CD4}^{+}$ & Linfócito $\mathrm{T} \mathrm{CD} 4^{+}$auxiliar \\
\hline $\mathrm{T} \mathrm{CD8}^{+}$ & Linfócito $\mathrm{T}$ CD8 ${ }^{+}$citotóxico \\
\hline $\mathrm{TCD4}^{+} \mathrm{CD}^{2} 5^{+} \mathrm{Foxp}^{+}$ & Linfócito $\mathrm{T}$ regulador do fenótipo $\mathrm{CD} 4^{+} \mathrm{CD} 25^{+} \mathrm{Foxp} 3^{+}$ \\
\hline TCR & "T cell receptor" \\
\hline TGF- $\beta$ & "Transforming growth factor $\beta "$ \\
\hline Th1 & Linfócito T “helper” tipo 1 \\
\hline Th2 & Linfócito T "helper" tipo 2 \\
\hline Th3 & Linfócito T "helper" tipo 3 \\
\hline Th17 & Linfócito T "helper" tipo 17 \\
\hline TLR & "Toll like receptor" \\
\hline TLR2 & "Toll like receptor" 2 \\
\hline TLR4 & "Toll like receptor" 4 \\
\hline TNFR & "Tumor necrosis factor receptor" \\
\hline TNF- $\alpha$ & "Tumor necrosis factor $\alpha "$ \\
\hline Treg & Célula $\mathrm{T}$ reguladora \\
\hline UFC & Unidades formadoras de colônias \\
\hline VCAM-1 & "Vascular cell adhesion molecule-1" \\
\hline WT & "Wide Type" \\
\hline WT anti-CD8 & Animal WT tratado com anticorpo anti-linfócito T CD8 \\
\hline WT anti-TNF- $\alpha$ & Animal WT tratado com anticorpo anti-TNF- $\alpha$ \\
\hline WT IgG & Animal WT tratado com anticorpo IgG normal de rato \\
\hline
\end{tabular}




\begin{abstract}
NO
$\mathrm{O}_{2}^{-}$

$\mathrm{ONOO}^{-}$

$\mathrm{O}_{2}$

$\mathrm{NaNO}_{2}$

$\mathrm{NaOH}$

$\mathrm{NH}_{4} \mathrm{Cl}$

$\mathrm{H}_{2} \mathrm{O}_{2}$

$\mathrm{H}_{2} \mathrm{SO}_{4}$
\end{abstract}

Oxido nítrico

Ânion superóxido

Peroxinitrito

Oxigênio

Nitrito de sódio

Hidróxido de sódio

Cloreto de amônio

Peróxido de hidrogênio

Ácido sulfúrico 


\section{SUMÁRIO}

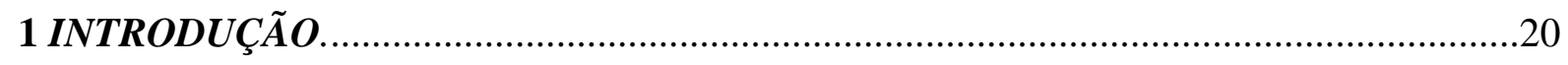

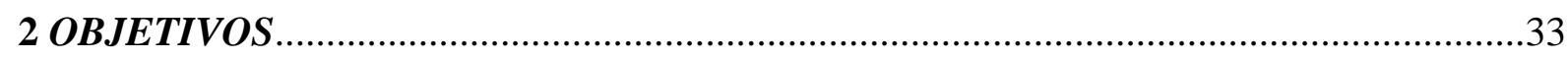

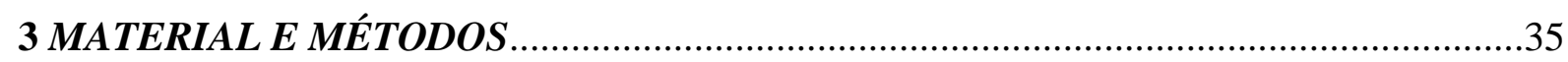

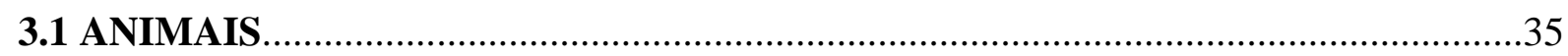

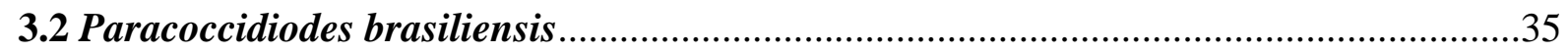

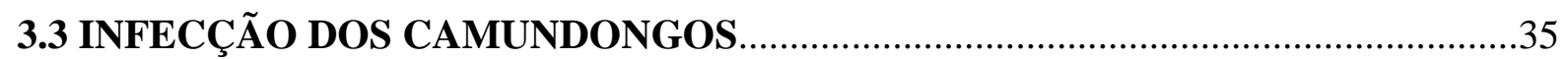

3.4 DETERMINAÇÃO DO NÚMERO DE UNIDADES FORMADORAS DE

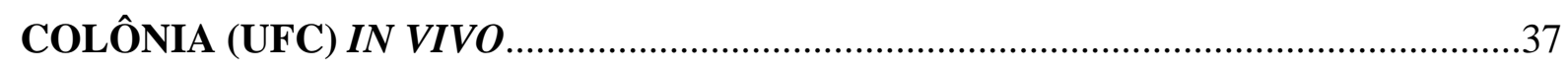

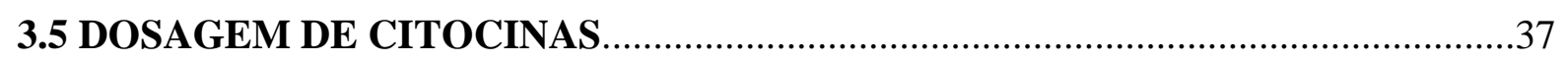

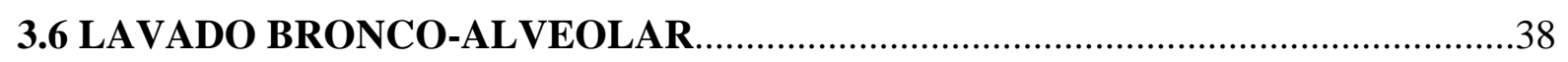

3.6.1 TRATAMENTO DE CULTURA DE MACRÓFAGOS..........................................39

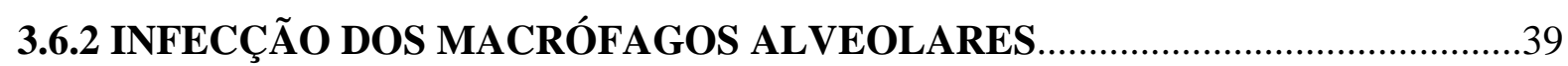

3.6.3 DETERMINAÇÃO DE UNIDADES FORMADORAS DE COLÔNIAS

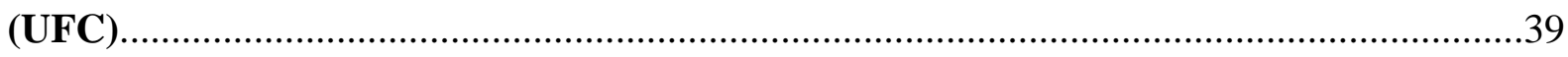

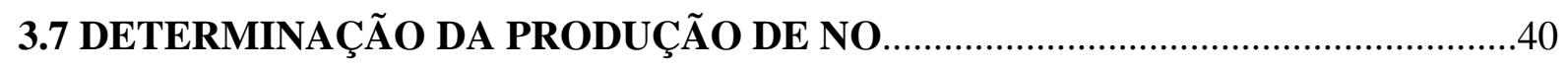

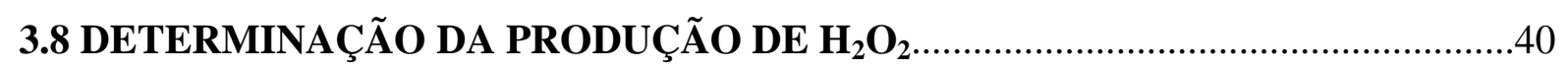

3.9 OBTENÇÃO DE LINFÓCITOS INFILTRANTES DE PULMÃO............................41

3.10 CITOMETRIA DE FLUXO PARA CARACTERIZAÇÃO DE SUBPOPULAÇÕES DE LINFÓCITOS E MONÓCITOS....................................................4

3.11 CITOMETRIA DE FLUXO PARA CARACTERIZAÇÃO DE CÉlULAS REGULADORAS T $\mathrm{CD4}^{+} \mathrm{CD}^{+} 5^{+}$ATRAVÉS DA EXPRESSÃO DO FATOR DE

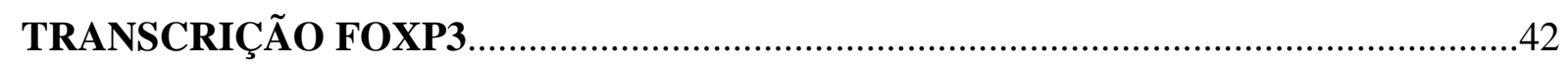

3.12 PRODUÇÃO E PURIFICAÇÃO DE ANTICORPOS MONOCLONAIS (ACM) EMPREGADOS NOS EXPERIMENTOS DE DEPLEÇÃO ........................................43

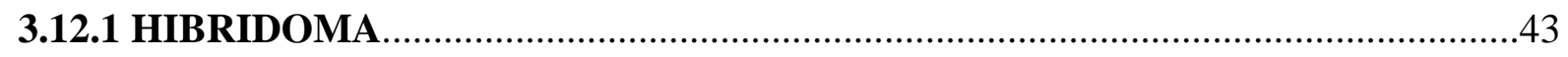

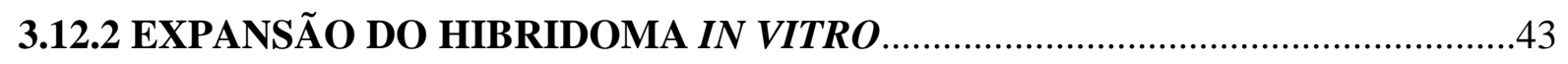

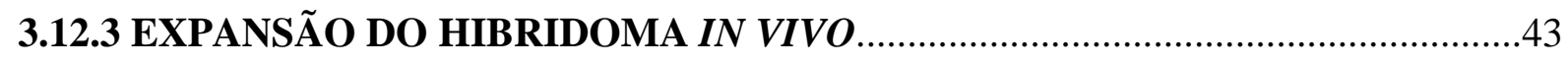

$\begin{array}{lllll}\text { 3.12.4 PRECIPITAÇÃO } & \text { E PURIFICAÇÃO DOS ANTICORPOS }\end{array}$

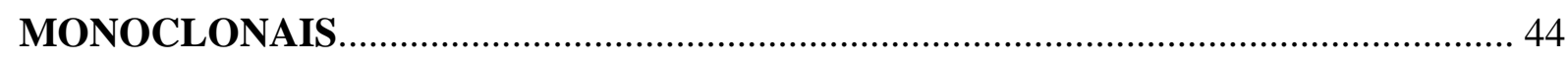


3.12.5 DOSAGEM DE PROTEÍNAS (MÉTODO DO ÁCIDO BICINCONÍNICO, BCA).

3.12.6 ANÁlise DO GRAU DE PUREZA DAS AMOSTRAS POR SDSPAGE. . .45

3.12.7 PURIFICAÇÃO DE $\gamma$-GLOBULINA NORMAL DE RATO..................................45

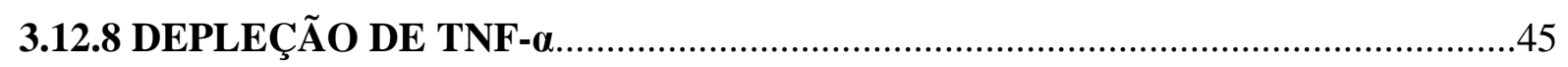

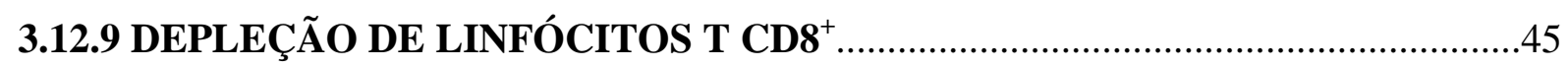

3.13 DETERMINAÇÃO DO TEMPO MÉDIO DE SOBREVIDA DOS CAMUNDONGOS TRATADOS COM ANTI-TNF- $\alpha$ .46

3.14 ANÁLISE HISTOPATOLÓGICA DOS PULMÕES..................................................46

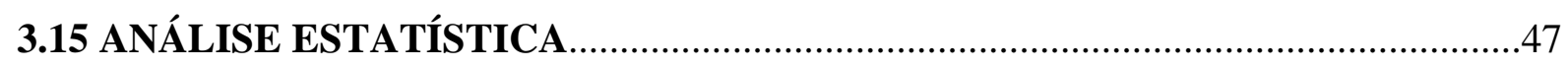

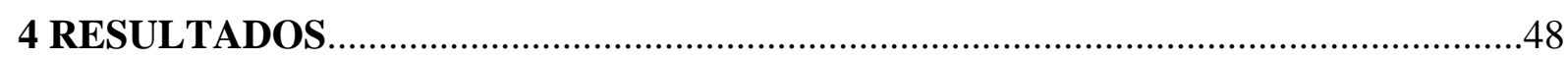

4.1 CARACTERIZAÇÃo DA GRAVIDAdE DA DOENÇA E PRODUÇÃo DE CITOCINAS POR CAMUNDONGOS iNOS KO E WT.................................................48

4.2 ESTUDO DA ATIVIDADE FUNGICIDA IN VITRO E DA PRODUÇÃO DE $\mathrm{H}_{2} \mathrm{O}_{2} \mathrm{E}$ NO POR MACRÓFAgOS ALVEOLARES DE CAMUNDONGOS INOS KO E SEU GRUPO CONTROLE APÓS 2 SEMANAS DE INFECÇÃO.

4.3 ESTUdO DA ATIVIDADE FUNGICIDA IN VITRO E DA PRODUÇÃO DE NO POR MACRÓFAgOS ALVEOLARES DE CAMUNDONGOS INOS KO E SEU GRUPO CONTROLE APÓS 10 SEMANAS DE INFECÇÃO. 54

4.4 ANÁLISE FENOTíPICA DE LINFÓCITOS INFILTRANTES DE PULMÃo DE ANIMAIS INOS KO E SEU GRUPO CONTROLE WT NAS SEGUNDA E DÉCIMA SEMANAS DE INFECÇÃO.

4.5 CARACTERIZAÇÃo da PRESENÇA dE CÉlulaS T REgUladoraS dO FENÓTIPO T $\mathrm{CD}^{+} \mathrm{CD}^{+} 5^{+} \mathrm{FOXP3}^{+}$NO PULMÃO DE ANIMAIS iNOS KO E SEU GRUPO CONTROLE WT NAS SEGUNDA E DÉCIMA SEMANAS DE INFECÇÃO. .59

4.6 ANÁLISE FENOTÍPICA DE MACRÓFAGOS ALVEOLARES DE ANIMAIS iNOS KO E SEU GRUPO CONTROLE WT NAS SEGUNDA E DÉCIMA SEMANAS DE INFECÇÃO.

4.7 EFEITO DA DEPLEÇÃO IN VIVO DA CITOCINA TNF- $\alpha$ NA GRAVIDADE DA DOENÇA.

4.8 EFEITO DA DEPLEÇÃo IN VIVO DA CITOCINA TNF- $\alpha$ NA PRODUÇÃo DE CITOCINAS PULMONARES E HEPÁTICAS. 
4.9 EFEITO DA DEPLEÇÃO IN VIVO DA CITOCINA TNF-a NAS SUBPOPULAÇÕES DE LINFÓCITOS INFILTRANTES DE PULMÃo DE CAMUNDONGOS iNOS KO E WT....

4.10 EFEITO DA DEPLEÇÃO IN VIVO DA CITOCINA TNF- $\alpha$ NOS MACRÓFAGOS INFILTRANTES DE PULMÃO DE CAMUNDONGOS iNOS KO E WT. 72

4.11 ANÁliSE HISTOPATOLÓGICA DOS PULMÕES DE ANIMAIS iNOS KO E SEU GRUPO WT TRATADOS COM ANTI-TNF- $\alpha$ NA OITAVA SEMANA DE INFECÇÃO.

4.12 EFEITO DA DEPLEÇÃO IN VIVO DE LINFÓCITOS T CD8 NA CARGA FÚNGICA PULMONAR DE CAMUNDONGOS iNOS KO E SEU GRUPO WT.........77

4.13 EFEITO DA DEPLEÇÃO IN VIVO DE LINFÓCITOS T CD8 NOS LINFÓCITOS INFILTRANTES DE PULMÃO DE CAMUNDONGOS iNOS KO E SEU GRUPO WT. 79

4.14 EFEITO DA DEPLEÇÃO IN VIVO DE LINFÓCITOS T CD8 NOS MACRÓFAgOS INFILTRANTES DE PULMÃO DE CAMUNDONGOS iNOS KO E SEU GRUPO WT. . .81

5 DISCUSSÃO. .83

6 CONCLUSÕES. 108 REFERÊNCIAS BIBLIOGRÁFICAS 110 ANEXO 


\section{INTRODUÇ̃̃O}

A Paracoccidioidomicose (PCM) é uma micose sistêmica de evolução aguda, subaguda ou crônica causada pelo fungo dimórfico o Paracoccidioides brasiliensis $(\mathrm{Pb})$. Foi Adolfo Lutz em 1908 que inicialmente descreveu os aspectos clínicos, histopatológicos e microbiológicos da doença, reconhecendo, portanto a natureza fúngica do agente (FRANCO et al., 1987). A PCM é uma micose profunda amplamente encontrada na América Latina e Central (México). Não só a incidência é variável entre os países, mas também entre distintas regiões no mesmo país. Como exemplo, observa-se um franco contraste entre a incidência rara nas regiões áridas e semiáridas do Nordeste do Brasil, ou ainda incomum nas regiões superúmidas da Amazônia, versus a alta incidência das regiões Centro e Sudeste do país (RESTREPO et al., 1985). Há evidências, portanto, de condições ecológicas que favorecem a sobrevida do $P$. brasiliensis na natureza em regiões endêmicas. Essas condições seriam: temperatura média entre $17^{\circ} \mathrm{C}-24{ }^{\circ} \mathrm{C}$, invernos relativamente curtos e não muito rigorosos, pluviosidade entre 500-2500 mm/ano, altitude entre o nível do mar e os $1500 \mathrm{~m}$, solos férteis e com cobertura vegetal (RESTREPO, 1994).

O P. brasiliensis é um fungo com características de dimorfismo térmico, que cresce como micélio à temperatura de $25{ }^{\circ} \mathrm{C}$ e como célula leveduriforme no tecido e in vitro a $37{ }^{\circ} \mathrm{C}$ (RESTREPO et al., 1985). Segundo San Blas et al. (1980) a temperatura parece ser o único fator que interfere no dimorfismo do $P$. brasiliensis e este processo é reversível.

O contágio parece ocorrer pela inalação de propágulos (conídios) infectantes que, atingindo os pulmões podem se desenvolver em leveduras e a partir do foco primário da infecção disseminar-se por via linfo-hematogênica para diferentes órgãos ou sistemas (RESTREPO et al., 1985). O desenvolvimento da PCM depende da interação entre o fungo e o hospedeiro, sendo a adesão às células e à superfície de mucosas do hospedeiro importantes no estabelecimento da infecção. Desta forma, $\mathrm{o} \mathrm{Pb}$ pode penetrar ativamente à superfície mucocutânea e parasitar as células epiteliais, escapando assim das defesas do hospedeiro e atingir os tecidos mais profundos por via linfo-hematogênica (BRITO et al., 1973).

A maioria dos indivíduos infectados desenvolve uma infecção pulmonar assintomática, são, porém, paracoccidioidina positivos e não apresentam sinais clínicos da doença. Correspondem àqueles que se infectaram, desenvolveram o complexo primário, mas não progrediram para a doença (ANGULO-ORTEGA, 1972). Recentemente, Mamoni et al. (2006) mostraram que esses indivíduos assintomáticos, infectados pelo $\mathrm{Pb}$ e quem não 
desenvolviam a doença, apresentavam uma resposta imunológica do perfil Th1 com predomínio de linfócitos $\mathrm{TCD}^{+}$citotóxicos os quais eram fonte de IFN- $\gamma$ e aumento de linfócitos $\mathrm{TCD}^{+}$auxiliares que produziam altos níveis de IL-2 e TNF- $\alpha$, além de maior expressão das quimiocinas CXCL9 e CXCL10 em linfócitos do sangue periférico as quais estão correlacionadas com a maior produção de IFN- $\gamma$. Porém, decorrente da progressão do complexo primário, da reativação do foco quiescente (reinfecção endógena) ou, ainda, de reinfecção exógena é que se desenvolvem manifestações clínicas da doença.

As manifestações clínicas são classificadas como Forma Aguda ou Juvenil (FJ) e Forma Crônica ou Adulta (FA) da PCM (FRANCO et al., 1989). A FJ acomete mais crianças e jovens com idade inferior aos 30 anos, de ambos os sexos, desenvolve-se em semanas ou em poucos meses após a exposição ao fungo. Ocorre o comprometimento do sistema mononuclear fagocítico, apresenta altos títulos de anticorpos, aumento de linfonodos e hepatoesplenomegalia (BENARD et al., 1994). Não são comuns evidências radiológicas de comprometimento pulmonar, assim como envolvimento da mucosa oral. Do ponto de vista imunológico, a FJ apresenta predominância de citocinas anti-inflamatórias, IL-10 e TGF- $\beta$ nos linfonodos desses pacientes (NEWORAL et al., 2003), altos níveis de anticorpos específicos IgG4 e de IgE, eosinofilia e resposta imune celular específica suprimida (BENARD et al., 1997; MAMONI et al., 2002).

A FA, por outro lado, é mais frequente, corresponde a aproximadamente $90 \%$ dos casos, acomete principalmente indivíduos do sexo masculino, geralmente lavradores rurais que apresentam maior contado com o fungo no solo numa possível área endêmica. Ainda, a FA apresenta longa duração; a instalação é lenta e gradual, resultando da reativação fúngica de focos quiescentes os quais podem persistir por décadas (FRANCO et al., 1989). Entre os fatores desencadeantes da doença, tem sido citados o alcolismo, a desnutrição e, em inúmeros casos, o tabagismo (MURRAY et al., 1974; LEMLE et al., 1983).

Ainda nesta forma clínica ocorre o comprometimento pulmonar, que é praticamente a regra de manisfestação clínica, com lesões granulomatosas, além de lesões em mucosas orais e linfonodos cervicais (MAGALHÃES et al., 1994). As lesões na cavidade oral são uma manifestação importante, pois permitem um diagnóstico clínico precoce (ALMEIDA e JUNIOR, 2003). Pode ocorrer disseminação para os linfonodos abdominais, fígado, baço, glândulas adrenais, pele, ossos e cérebro (RESTREPO, 2000; FAICAL, 1996). Esta bem estabelecida que a maioria dos pacientes com paracoccidioidomicose que desenvolvem lesões na mucosa oral refere-se a indivíduos masculinos que desenvolvem a forma crônica da doença (BLOTTA, 1999). O estudo de Villalba (1998) mostrou que em 64 casos de pacientes com 
PCM, 93\% são homens, com idade média de 43 anos e a proporção entre homens e mulheres era de 15:1. Deste modo, a suspeita de que fatores hormonais femininos poderiam conferir proteção contra o desenvolvimento da PCM foi apoiada pela observação de estudos que mostraram que o hormônio 17- $\beta$ estradiol inibia a conversão de fase de conídio infectante para levedura patogênica (ARISTIZABAL et al., 1998). O mecanismo pelo qual o 17- $\beta$ estradiol atua no $P$. brasiliensis seria o bloqueio da síntese de proteínas que se expressam durante a transformação da fase de micélio para levedura. Portanto, através desses mecanismos, o estrógeno pode interferir na patogenicidade do P. brasiliensis (LOOSE et al., 1983). Além disso, estudos recentes demostraram que o 17- $\beta$ estradiol pode induzir in vitro a produção de óxido nítrico (NO) e aumento da expressão da enzima óxido nítrico sintase induzida (iNOS) em macrófagos peritoneais. (HONG e ZHU, 2004).

Do ponto de vista imunológico, Baida et al. (1999) demonstraram que a FA apresenta níveis elevados de citocinas do padrão Th1 (IFN- $\gamma$ ) além de anticorpos específicos IgG2 e IgA de mucosa, sugerindo certo controle da infecção e doença menos grave. As lesões de mucosa oral, típicas nessa forma clínica são ricas de linfócitos $\mathrm{T} \mathrm{CD}^{+}$que contem a quantidade de fungos na lesão (NEWORAL et al., 2003). Há, porém, casos graves associados com ativação exacerbada da imunidade humoral, prevalência de citocinas do padrão Th2 e imunidade celular deprimida.

Assim, os indivíduos que apresentam maior controle sobre a produção de anticorpos e apresentam imunidade celular preservada, correspondem à doença menos grave, enquanto que a presença de hipergamaglobulinemia, formação de imune complexos séricos, ativação policlonal de linfócitos B, relacionam-se aos quadros de maior gravidade da PCM (ARANGO e YARZABAL, 1982; SINGER-VERMES et al., 1993; CANO et al., 1995).

Uma característica que deve ser salientada em relação ao $P$. brasiliensis é o seu principal componente antigênico, a glicoproteína de $43 \mathrm{kDa}$, a gp43, encontrada na parede fúngica, e que desencadeia forte resposta imune humoral, caracterizada pela presença de anticorpos no soro de 100\% dos pacientes com PCM (TRAVASSOS et al., 1995; TABORDA et al., 1998; MENDES-GIANINNI et al., 1989; PUCCIA et al., 1986). Estudos sobre a importância e função da gp43 foram desenvolvidos por Popi et al. (2002) que demonstraram que esta glicoproteína diminuía a capacidade de fagocitose (via receptor de manose) de macrófagos peritoneais in vitro, de animais $\mathrm{A} / \mathrm{Sn}$ e $\mathrm{B} 10$. $\mathrm{A}$, frente ao $\mathrm{Pb}$, além de prejudicar a atividade microbicida dos macrófagos com a diminuição da produção de $\mathrm{NO}$ e $\mathrm{H}_{2} \mathrm{O}_{2}$. Em recente trabalho, Konno et al. (2009) mostraram que dois principais peptídeos, o P4 e o P23, 
constituintes desta gp43, inibiam a atividade fungicida de macrófagos murinos in vitro e que essa atividade fungicida era dependente de $\mathrm{NO}$ e não de $\mathrm{H}_{2} \mathrm{O}_{2}$, já que houve redução dos níveis de NO. Além disso, in vivo, observou-se que a adição desses peptídeos nos testes de hipersensibilidade do tipo tardio, reduzia o infiltrado inflamatório no coxim plantar dos animais. Deste modo, pode-se sugerir que a síntese de gp 43 funciona como um mecanismo de evasão do $P$. brasiliensis, frente o sistema imune do hospedeiro, proporcionando assim a instalação do patógeno.

Sabe-se que os mecanismos imunológicos do hospedeiro influenciam na manifestação e gravidade das infecções fúngicas. Por exemplo, a ativação do sistema imune é o principal determinante do tipo de doença que irá se desenvolver depois da exposição ao fungo oportunista Aspergillus fumigatus (MARR et al., 2002); ou se irá ocorrer a transição da forma comensal para a infecção por Candida albicans (FIDEL e SOBEL, 1994). Assim, nas doenças infecciosas, os mecanismos de proteção do hospedeiro dependem da combinação de múltiplos fatores incluindo tanto a imunidade inata quanto a adaptativa. Desta forma, nos estágios iniciais da doença os mecanismos de resistência natural, que correspondem às barreiras de mucosas do trato gastrointestinal, gênitourinário e respiratório, funcionam para conter a disseminação do fungo, porém não são suficientes para a proteção completa contra a doença.

A resposta imune inata contra os fungos, por sua vez, baseia-se no reconhecimento de estruturas moleculares conservadas encontradas em inúmeros grupos de microrganismos, os PAMPS ("pathogen-associated molecular patterns”) (JANEWAY e MEDZHITOV, 2002) que são reconhecidos pelos seus receptores, os PRR ("pattern recognition receptors”), sendo os TLR (“toll like receptors”) um dos grupos mais importantes. Os TLRs compreendem vários componentes designados de TLR1 a TLR9, que reconhecem diferentes estruturas moleculares nos patógenos, e estão presentes nas membranas celulares e endocelulares das células da imunidade inata; há ainda os receptores do tipo lectinas-c como os receptores para manose (MR), dectina 1 e 2 que reconhecem $\beta$-glucanas e os receptores tipo "scavenger" também presentes em células da imunidade inata, como neutrófilos $(\mathrm{PMN})$, macrófagos $(\mathrm{M} \phi)$ e células dendríticas (DC) possibilitando a fagocitose dos patógenos (GORDON, 2002; BROWN e GORDON, 2003; AKIRA et al., 2006). Os TLRs são importantes em inúmeros aspectos na eliminação de micro-organismos. Sua ativação leva à produção de inúmeras moléculas de adesão e estimuladoras, dentre elas as quimiocinas que participam do recrutamento de fagócitos para o foco da infecção. A ativação de DCs, via TLRs, tornam estas células imunogênicas e com habilidade de induzir a ativação de linfócitos T "helper" Th1, Th2, ou Th17 responsáveis pela resposta imune adaptativa. Por exemplo, os TLR4 de DCs 
estimuladas com LPS produzem altos níveis de IL-12 e TNF- $\alpha$, e baixos níveis de IL-10, favorecendo a resposta do tipo Th1 (REIS E SOUSA, 2004). Netea et al. (2002) foram os primeiros a descreverem a importância dos TLRs no reconhecimento de estruturas fúngicas no modelo de Candida albicans no qual animais deficientes geneticamente de TLR4 apresentavam maior suscetibilidade à candidíase e menor recrutamento de neutrófilos para o foco da infecção, comparado ao grupo controle. Recentemente, nosso laboratório mostrou o papel destes receptores TLR na imunidade inata frente ao P. brasiliensis. Em revisão recente de Calich et al. (2008) foi relatado que camundongos deficientes de TLR2 e TLR4 e infectados pelo $\mathrm{Pb}$, apresentavam menor carga fúngica pulmonar, com diminuição da produção de NO e de IL-12, aumento de IFN- $\gamma$, diminuição do recrutamento de células mononucleares para os pulmões (macrófagos e linfócitos T CD4 ativados), paralelo aos níveis diminuídos da quimiocina MCP-1; havia, porém, aumento de neutrófilos para o foco da infecção. O resultado oposto, entretanto, foi visto com animais deficientes da proteína adaptadora MyD88, responsável pela ativação via NFkB de todos os TLRs, (TAKEDA e AKIRA, 2005). A infecção de camundongos $\mathrm{MyD} 88^{-/-}$pelo $\mathrm{Pb}$ resultou em doença mais grave com maior carga fúngica, aumento da mortalidade e níveis diminuídos de citocinas proinflamatórias e de óxido nítrico (CALICH et al., 2008). Assim, estes estudos mostraram que a deficiência de MyD88 parece ser mais importante do que a deficiência de TLR2 e TLR4 na PCM murina e que o P. brasiliensis parece utilizar destes TLRs como mecanismo de virulência pois facilita o acesso do fungo aos macrófagos garantindo sua multiplicação no hospedeiro.

Além da importância dos receptores do tipo TLR, os receptores para C3b (CR3, $\mathrm{CD} 11 \mathrm{~b} / \mathrm{CD} 18)$ que são integrinas de membranas que reconhecem iC3b do sistema complemento, além de receptores de $\beta$-glucanas e outros componentes da parede celular dos fungos que apresentam manose (BROWN e GORDON, 2003), são importantes no reconhecimento do patógeno. Nosso laboratório mostrou que a interação do P. brasiliensis com macrófagos peritoneais de camundongos era potencializada pela opsonização das leveduras por iC3b (CALICH et al., 1979).

Além dos receptores responsáveis pelo reconhecimento de patógenos durante a resposta imune inata é importante lembrar que a síntese de quimiocinas favorece o recrutamento e direcionamento de fagócitos, além disso, a síntese de citocinas (IFN- $\gamma$ e IL-12, produzidas por linfócitos T e células NK) aumenta o "burst" oxidativo de neutrófilos, com a produção de radicais de oxigênio, bem como potencializa a fagocitose de macrófagos. Os PMN são amplamente encontrados em lesões de pacientes com PCM (NEWORAL et al., 
2003) e participam das respostas inflamatórias ao P. brasiliensis através da liberação de radicais de oxigênio e nitrogênio; grânulos citoplasmáticos de peroxidase que são liberados durante a fagocitose e participam da morte de leveduras ingeridas ou extracelulares (MELONI-BRUNERI et al., 1996; GONZALEZ et al., 2000). Já a imunidade adaptativa caracteriza-se principalmente pela utilização do repertório heterogêneo de linfócitos $\mathrm{T} \mathrm{CD} 4^{+} \mathrm{e}$ $\mathrm{T} \mathrm{CD} 8^{+}$que produzem citocinas, além de anticorpos que podem funcionar como opsoninas.

Calich et al. (1985) desenvolveram um modelo de infecção intraperitoneal (i.p.) com o $P$. brasiliensis e demonstraram que entre várias linhagens isogênicas de camundongo havia diferenças significantes na suscetibilidade ao fungo. Foram caracterizadas como as mais resistentes as linhagens $\mathrm{A} / \mathrm{Sn}$ e $\mathrm{A} / \mathrm{J}$, enquanto que animais B10.A mostraram-se altamente suscetíveis à infecção pelo fungo. Estudos desenvolvidos em nosso laboratório têm utilizado um modelo de PCM pulmonar empregando as mesmas linhagens de camundongos, utilizando, porém, a via intratraqueal (i.t.) de infecção. Foi observado que camundongos A/Sn desenvolvem PCM crônica, benigna, restrita aos pulmões, caracterizada por limitado número de lesões granulomatosas bem organizadas com poucas leveduras viáveis. Animais B10.A, ao contrário, desenvolvem doença disseminada, progressiva, caracterizada pela presença de numerosas lesões granulomatosas mal organizadas contendo muitos fungos viáveis, além de serem anérgicos nas reações de hipersensibilidade do tipo tardio (CALICH et al., 1994). Os resultados obtidos sugeriram que a resistência à PCM estava associada à atividade de linfócitos T, macrófagos e células B mediadas por IFN- $\gamma$ (CANO et al., 1995). Estudos in vivo demonstraram ainda que o IFN- $\gamma$ tem efeito protetor na PCM pulmonar. A depleção de IFN- $\gamma$ por anticorpos monoclonais agravou a doença, tanto em animais suscetíveis, como em animais resistentes ao fungo desencadeando exacerbada infecção pulmonar, disseminação para fígado e baço, diminuição da resposta imune celular específica e aumento dos níveis de anticorpos específicos (CANO et al., 1998). Souto et al. (2000) ao estudarem o papel do IFN$\gamma$ (com animais GKO, deficientes do gene funcional para IFN- $\gamma$ ) e do TNF- $\alpha$ (através de animais p55KO, deficientes para o componente de $55 \mathrm{kDa}$ do receptor de TNF- $\alpha$ ) na resistência à infecção ao $\mathrm{Pb}$, demonstraram que ambas citocinas atuam no mecanismo de resistência à doença, e cuja presença leva a infecção com menor carga fúngica nos pulmões, formação de granulomas bem organizados e maior sobrevida aos animais. Além disso, o IFN$\gamma$ induz a produção de óxido nítrico que determina anergia de células $\mathrm{T}$ e diminui a proliferação celular. 
Estudos realizados com modelo i.p. e com o modelo pulmonar da PCM demonstraram que a infecção pelo $P$. brasiliensis leva a diferentes graus de ativação de macrófagos, que dependem do padrão genético da linhagem de camundongo empregada (KASHINO et al., 1985). Macrófagos alveolares de camundongos resistentes produzem altos níveis de peróxido de hidrogênio a partir do segundo mês de infecção, enquanto que aqueles de animais suscetíveis não o fazem (CANO et al., 1995).

Uma outra citocina que deve ser destacada é a IL-12, produzida por macrófagos, cuja importância é atribuída à estimulação de produção de IFN- $\gamma$ por linfócitos $\mathrm{T}$ e células NK (CHAN et al., 1991). Arruda et al. (2002) mostraram no modelo i.t. da PCM murina que a administração da IL-12 recombinante em animais suscetíveis resultava em doença menos grave atribuída ao aumento de IFN- $\gamma$, diminuição da disseminação fúngica para fígado e baço, além de maior recrutamento de células mononucleares para o pulmão, induzindo, entretanto, uma grande atividade inflamatória local podendo ser prejudicial ao hospedeiro.

Estudos recentes em nosso laboratório mostraram os efeitos opostos atribuídos à citocina do tipo Th2, a IL-4, na PCM murina. A utilização de camundongos geneticamente deficientes para o gene da IL-4, em relação aos animais IL-4 normais, demonstrou que a ausência de IL-4 resulta em menor carga fúngica pulmonar, presença de níveis elevados de IFN- $\gamma$ no pulmão nas fases aguda e crônica da doença, ao maior afluxo de células PMN e maior produção de NO por macrófagos alveolares in vitro. Deste modo, estes resultados mostram que a deficiência de IL-4 parece exercer papel protetor na PCM pulmonar (PINA et al., 2004). Arruda et al. (2004) mostraram que dependendo do padrão genético do hospedeiro, a citocina IL-4 pode ter papel protetor ou exacerbador na PCM murina. A neutralização da citocina IL-4, com anticorpo anti-IL-4, em animais suscetíveis B10.A levou ao aumento da carga fúngica pulmonar enquanto que em animais que apresentavam suscetibilidade intermediária C57BL/6, a neutralização de IL-4 direcionou a um quadro de PCM menos grave com menor carga fúngica nos pulmões, histologia pulmonar organizada em granulomas, aumento dos níveis das citocinas TNF- $\alpha$ no pulmão e de IL-12 no fígado, com redução dos níveis pulmonares e hepáticos de IL-5 e aumento do nível do isótipo IgG2a.

Em um modelo de infecção in vitro por conídios de $P$. brasilienis em macrófagos peritoneais murinos, Gonzalez et al. (2000) demonstraram que o óxido nítrico (NO) induzido pela ativação de macrófagos por IFN- $\gamma$ participa da inibição da transformação dos esporos em células leveduriformes e da estimulação da atividade fungicida. Estes resultados estão de acordo com aqueles obtidos por Bocca et al. (1998) que demonstraram que o tratamento in 
vivo com um inibidor de óxido nítrico agrava a doença de camundongos (C57BL/6) infectados pelo $P$. brasiliensis. No curso da doença, entretanto, o NO também induz imunossupressão que se manifesta por diminuição da expressão de antígenos Ia (MHC de classe II) em macrófagos, prejudicando desta forma a apresentação antigênica para os linfócitos T e consequente redução da linfoproliferação (BOCCA et al., 1998, 1999).

Nesta mesma linha, nosso laboratório demonstrou que macrófagos de animais resistentes produzem baixos níveis de $\mathrm{NO}$ e altos de TNF- $\alpha$, enquanto que macrófagos de camundongos suscetíveis estimulados por leveduras vivas do fungo produzem níveis elevados de NO e baixos de TNF- $\alpha$ (NASCIMENTO et al., 2002). Seguindo este comportamento de macrófagos de animais resistentes e suscetíveis, recentemente, verificamos que os macrófagos alveolares de animais B10.A, além de secretarem níveis elevados de NO, apresentam atividade microbicida eficiente contra o P. brasiliensis, enquanto que os macrófagos de animais A/J mostraram baixa atividade fungicida relacionada com níveis diminuídos de NO e produção de TGF- $\beta$ (PINA et al., 2008).

Assim, o óxido nítrico, na PCM murina, pode estar associado com a proteção, devido à sua capacidade microbicida, mas também com a exacerbação da doença, já que pode estar relacionado com efeito imunossupressor da imunidade celular.

O óxido nítrico é um radical livre gasoso que funciona predominantemente como molécula mensageira e efetora de vários processos biológicos. Em mamíferos a síntese de NO é catalisada por um grupo de enzimas denominadas NO-sintases (NOS) (KNOWLES e MONCADA, 1994). Há três isoformas de NO-sintase (NOS): NOS I (neuronal ou nNOS), NOS II (induzida ou iNOS) e a NOS III (endotelial ou eNOS) (KNOWLES, 1996). Todas estas isoformas usam a L-arginina como substrato e vários tipos de cofatores ou coenzimas (KNOWLES e MONCADA, 1994). A reação catalíca parece ocorrer em duas fases. Na primeira ocorre a hidroxilação da L-arginina pelo $\mathrm{O}_{2}$ e NADPH dando origem a N-hidroxi-Larginina. Na segunda fase este composto é oxidado resultando na formação de L-citrulina, hidrogênio e NO.

A iNOS tem sido demonstrada estar presente em vários tecidos e células tais como macrófagos, condrócitos, células de Kupffer, hepatócitos, neutrófilos, epitélio pulmonar e vasos (MACMICKING et al., 1997) e produz NO em resposta a vários estímulos celulares, tais como a endotoxina bacteriana (LPS) e mediadores endógenos proinflamatórios.

A expressão do gene da iNOS é controlada por um grande número de agonistas, especialmente as citocinas proinflamatórias tais como TNF- $\alpha$, IL-1 $\beta$ e IFN- $\gamma$ e é inibida pelas 
citocinas do tipo Th2, IL-4 (BOGDAN et al., 1994), IL-8 (MCCALL et al., 1992), IL-10 (CUNHA et al., 1992) e TGF- $\beta$ (SCHINI et al., 1992), além da quimiocina MCP-1 (“monocyte chemoattractant protein-1") (ROJAS et al., 1993).

A atividade química do NO é complexa e sua reação com o oxigênio ou com espécies reativas do oxigênio (ROI) produz vários compostos reativos do nitrogênio e do oxigênio. Uma das reações melhor estudada é aquela entre o $\mathrm{NO}$ e ânions superóxido $\left(\mathrm{O}_{2}{ }^{-}\right)$produzindo o peroxinitrito $\left(\mathrm{ONOO}^{-}\right)$que é um potente oxidante de proteínas (VASQUEZ-TORRES et al., 1995). O NO ainda inativa na célula alvo enzimas cruciais para o ciclo de Krebs, cadeia de transporte de elétrons, síntese de DNA e interrompe o mecanismo de proliferação celular. (MONCADA, 1991).

$\mathrm{O}$ efeito microbicida do NO em infecções bacterianas ocorre de duas maneiras: primeiramente o IFN- $\gamma$ e TNF- $\alpha$ (produzidos por células $\mathrm{T}$ ou outras células) ativam os macrófagos promovendo a expressão de iNOS e síntese de NO. Durante a fagocitose há também o aumento do "burst" oxidativo, além da atividade citostática e citotóxica sobre esses microorganismos, incluindo Mycobacterium tuberculosis (MACMICKING et al., 1997), Staphylococcus aureus (JACKSON et al., 1995) e Escherichia coli (BRUNELLI et al., 1995), Candida albicans (REMENTERIA et al., 1995), Paracoccidioides brasiliensis (GONZALEZ et al., 2000) dentre outros.

Macrófagos peritoneais e alveolares de camundongos são capazes de matar leveduras de Histoplasma capsulatum por um mecanismo dependente de peróxido de hidrogênio e NO, enquanto que o efeito fungistático depende somente de produtos da via de ativação da iNOS (BRUMMER e STEVENS, 1995). Ainda na histoplasmose, verificou-se que a expressão de iNOS pelos macrófagos de camundongos infectados com o fungo estava associada com a apoptose de linfócitos do baço e com a inibição da linfoproliferação (WU-HSIEH et al., 1998).

Um dos exemplos mais elegantes e bem estudados da dupla função (protetora e imunossupressora) do NO na resposta imune contra patógenos é aquele descrito por Einsenstein (2001) com o modelo de imunoproteção contra Salmonella. Verificou-se que no momento de maior proteção induzida por vacina de bactéria viva havia concomitante imunossupressão da resposta proliferativa de linfócitos a mitógenos (EINSENSTEIN et al., 1984) e da produção de anticorpos para antígenos T-dependentes (eritrócitos de carneiro). Esta supressão era profunda, estava associada à presença de macrófagos, porém a competência imunológica era recuperada no dia 21 após a vacinação. Estudos subsequentes 
demonstraram que a imunossupressão estava associada à produção de IFN- $\gamma$ e que a IL-4 bloqueava a síntese de NO e a imunossupressão (AL-RAMADI et al., 1991). De maneira análoga ao observado por Einsenstein com a Salmonella, no modelo de infecção i.p. pelo $P$. brasiliensis o NO parece estar exercendo uma dupla função: induz a atividade fungicida dos macrófagos, mas leva à supressão da linfoproliferação e da resposta imune.

Essa supressão linfocitária foi estudada por Millar et al. (1999) que verificaram nos animais iNOS KO, infectados por T. brucei, aumento dos níveis de IFN- $\gamma$ e de linfócitos T $\mathrm{CD}^{+}$ativados no baço sendo que o contrário foi visto nos animais iNOS normais. Nessa mesma linha de raciocínio, Niedbala et al. (1999) verificaram no modelo de infecção por $L$. major que doses elevadas de NO inibiam a diferenciação de linfócitos Th1 e diminuíam os níveis de IFN- $\gamma$.

Ao mesmo tempo em que o NO é importante no controle da multiplicação fúngica, inibe a produção de TNF- $\alpha$, que é essencial para o controle da disseminação fúngica (SOUTO et al., 2000), uma vez que essa citocina participa na formação de granulomas (KINDLER et al., 1989) e juntamente com IFN- $\gamma$ ativa os macrófagos potencializando o "killing" ao $P$. brasiliensis (BRUMMER et al., 1988). Além disso, o TNF- $\alpha$ proporciona aumento da produção de quimiocinas que induzem a quimiotaxia de leucócitos e recrutamento de células inflamatórias (MEHRAD et al., 1999), participa na diferenciação de macrófagos em células epitelióides (TRACEY e CERAMI, 1993) e ainda estimula a expressão de moléculas de adesão celular ICAM-1 e VCAM-1 no endotélio e em inúmeras superfícies celulares; proporcionam, assim, um melhor recrutamento celular para a formação de granulomas bem organizados (RESNICK e WELLER, 1993). Chu et al. (1996) demonstraram que as citocinas TNF- $\alpha$ e IL- $1 \alpha$ estão envolvidas no aumento da expressão de ICAM-1 nos processos inflamatórios. Vale lembrar que o NO inibe a expressão dessa molécula de adesão, prejudicando dessa forma o recrutamento celular (CAYATTE et al., 1997).

Vários estudos mostraram a importância do papel atribuído ao IFN- $\gamma$ e ao NO na apoptose de células imunes durante um processo infeccioso. Durante a infecção de camundongos por Toxoplasma gondii, a neutralização de IFN- $\gamma$ resultou em diminuição dos níveis de apoptose dos linfócitos da placa de Peyer, além de redução da expressão celular de FasL (LISENFELD et al., 1997). Dalton et al. (2000) mostraram que o IFN- $\gamma$ era responsável pelos níveis de apoptose de células $\mathrm{T} \mathrm{CD}^{+}$esplênicas quando infectados pelo M. bovis em modelo murino de IFN- $\gamma$ KO. Além disso, o óxido nítrico estava intimamente relacionado 
com a indução de apoptose de linfócitos $\mathrm{T} \mathrm{CD}^{+}$, sendo que os níveis celulares eram restaurados quando se utilizava um inibidor da síntese de NO, o LMNA.

Pacientes com paracoccidioidomicose pulmonar apresentam na superfície de leucócitos de sangue periférico aumento de FasL e de ligantes para Anexina V (marcadores de apoptose inicial) além de CTLA-4 (inibidor a ativação prolongada de células T); estes aumentos estavam associados à redução da proliferação celular e níveis aumentados da citocina anti-inflamatória TGF- $\beta$ em culturas celulares (CAMPANELLI et al., 2003).

Recentemente tem sido demonstrada a participação de outra sub-população celular nos mecanismos reguladores da imunidade e processos inflamatórios, a sub-população T CD4 reguladora. Essas células apresentam o fenótipo $\mathrm{T} C D 4^{+} \mathrm{CD} 25^{+}$, expressam de maneira constitutiva o marcador CD25 (cadeia $\alpha$ do receptor de IL-2), CTLA-4 (“cytotoxic T lymphocyte-associated antigen"- inibidor da ativação prolongada de linfócitos T) (BELKAID e ROUSE, 2005), GITR ("glucocorticoid-induced tumor necrosis factor receptor"), ou TNFR (SHEVACH et al., 2002), CD45RO (DIECKMAN et al., 2001), TGFß1 de membrana (NAKAMURA et al., 2004) e o fundamental fator de transcrição nuclear Foxp3 ${ }^{+}$ (FONTENOT e RUDENSKY, 2005).

Células Treg atuam através da inibição da produção de IL-2 bloqueando o ciclo celular de linfócitos $\mathrm{T} \mathrm{CD}^{+}$e $\mathrm{T} \mathrm{CD}^{+}$, além de suprimir a atividade proliferativa de linfócitos CD4 ${ }^{+}$CD25- (NAKAMURA et al., 2001). O possível mecanismo da ação supressora dessas Treg se dá pelo contato direto célula-célula, envolvendo sinais inibidores através da sinalização mediada por CTLA-4, GITR e TGF- $\beta$ de membrana (READ, et al., 2000; SHIMIZU et al., 2002; NAKAMURA et al., 2001), ou pela produção, mas não exclusivamente dessas células, das citocinas anti-inflamatórias IL-10 e TGF- $\beta$ (ASSEMAN et al., 1999). Muitos trabalhos relatam a importância dessas células reguladoras em casos crônicos de infecção onde, devido à persistência do patógeno, essas células estariam controlando as respostas imunes que poderiam causar quadros inflamatórios exacerbados na tentativa de erradicar o agente infeccioso. Além disso, por impedirem a cura asséptica, as células Treg controlariam a manutenção da memória imunológica.

Assim, quadros crônicos de tuberculose (GEROSA, 1999), malária (PLEBANSKI, 1999) e AIDS (OSTROWSKI, 2001) mostram que a persistência do patógeno está relacionada com a presença de células $\mathrm{T}$ reguladoras juntamente com a síntese de citocinas antiinflamatórias IL-10 e TGF- $\beta$. É ainda interessante o fato de que em infecções crônicas como na leishmaniose, ocorre a persistência de células $\mathrm{T}$ reguladoras naturais de fenótipo $\mathrm{T}$ $\mathrm{CD} 4^{+} \mathrm{CD} 25^{+} \mathrm{Foxp}^{+}$, síntese aumentada de IL-10 e níveis reduzidos de IFN- $\gamma$ (BELKAID et 
al., 2002). Porém, a permanência dessas células está relacionada com a homeostase do sistema imune, uma vez que minimizam os efeitos deletérios da inflamação (atribuída à produção de radicais de oxigênio e nitrogênio) durante a tentativa de eliminar o patógeno nos tecidos, trabalhando assim como um "feedback negativo" na ativação das respostas imunes (POWRIE et al., 2003). Cavassani et al. (2006) mostraram na paracoccidioidomicose crônica, forma adulta, que pacientes que apresentavam doença grave tinham aumento de células Treg $\mathrm{TCD}^{+} \mathrm{CD} 25^{+} \mathrm{Foxp}^{+}$nas biópsias de lesões teciduais que continham grande carga fúngica. Essas células apresentavam receptores de migração para os tecidos lesados, ou seja, receptores de "homing", CCR5 e CCR4, para as quimiocinas CCL5 e CCL22, respectivamente. Em concordância com esses resultados, Moreira et al. (2008) mostraram que animais deficientes de CCR5 apresentavam menor infiltrado de células Treg Foxp $3^{+}$nas lesões e ainda maior controle do crescimento fúngico; mostrou-se, assim, que este receptor era fundamental para o recrutamento de Tregs para o local da infecção onde há persistência do patógeno.

Em nosso trabalho desenvolvido durante o mestrado foi observado um duplo papel atribuído ao $\mathrm{NO}$ em tempos distintos da infecção pelo $\mathrm{Pb}$ em camundongos geneticamente deficientes da enzima iNOS. Assim, na fase aguda, a deficiência de NO resultou em menor número de UFC no pulmão desses animais, aumento da maioria das citocinas do tipo Th1 (TNF- $\alpha$, IFN- $\gamma$, IL-2) e dos isótipos IgG2a e IgG3; já na fase crônica, por outro lado, os animais iNOS KO apresentaram maior carga fúngica pulmonar, níveis elevados da maiorias dos isótipos (IgG2a, IgG2b, IgG1, IgG3) e das citocinas (IFN- $\gamma$, IL-4 e IL-5). Verificamos também aumento bastante significativo dos níveis de TNF- $\alpha$ pulmonar nos animais $\mathrm{KO}$ nas primeiras 2 semanas de infecção. Ao analisarmos, entretanto, a histologia pulmonar desses animais, verificamos a presença de lesões bem organizadas em granulomas que limitavam uma maior disseminação fúngica para outros órgãos, proporcionando uma sobrevida média equivalente aos animais iNOS normais.

Assim, em nosso doutorado, propusemo-nos a melhor caracterizar os mecanismos protetores e exacerbadores na PCM mediados pelo NO em dois períodos da doença (fases aguda e crônica). Consideramos importante o estudo in vitro da atividade fungicida dos macrófagos alveolares de animais iNOS KO e de animais iNOS normais, do infiltrado célular pulmonar de linfócitos efetores e reguladores e de macrófagos de ambas as linhagens de camundongos. Verificamos anteriormente que o NO está relacionado com a citocina TNF- $\alpha$ e como nosso trabalho mostrou que níveis aumentados dessa citocina estão presentes nos 
pulmões quando a doença é menos grave nos animais deficientes de NO, propusemo-nos estudar o efeito da depleção desta citocina nas fases aguda e crônica do nosso modelo. 


\section{OBJETIVOS}

O propósito deste trabalho foi avaliar a importância dos efeitos protetores e deletérios do óxido nítrico (NO) na paracoccidioidomicose pulmonar murina. Para tanto, foi desenvolvido um modelo experimental de infecção utilizando camundongos C57BL/6 geneticamente deficientes para o gene iNOS (iNOS KO) e seus controles normais WT. Observação anterior demonstrava que a infecção era menos grave em animais deficientes de NO e isto estava associado ao aumento dos níveis de TNF- $\alpha$ pulmonar. Na fase crônica da infecção, apesar de maior carga fúngica dos animais deficientes, observamos lesões pulmonares organizadas em granulomas que mantinham o fungo no foco primário da infecção. O destino da infecção era, entretanto, equivalente em ambas as linhagens que apresentavam tempo de sobrevida semelhante. Assim, no presente trabalho propusemo-nos a melhor caracterizar o papel do NO na PCM usando animais normais e iNOS deficientes. Estudamos também a função do TNF- $\alpha$ neste modelo experimental através da sua neutralização in vivo. Inicialmente a doença foi estudada comparativamente quanto:

- $\quad$ a gravidade de infecção pulmonar e disseminação para fígado e baço através da quantificação de fungos viáveis pela técnica de Unidades Formadoras de Colônias (UFC) nas 2, 6 e 10 semanas de infecção de animais KO e WT;

- $\quad$ a presença de citocinas pulmonares de animais KO e WT nas segunda e décima semanas de infecção;

- $\quad$ a atividade fungicida in vitro de macrófagos alveolares de animais KO e WT nas fases aguda e crônica;

- ao infiltrado inflamatório de linfócitos, células T reguladoras e macrófagos nos pulmões de animais KO e WT nas fases aguda e crônica da doença;

- a histopatologia das lesões pulmonares de animais KO e WT na décima semana de infecção.

Estudamos também o efeito da depleção in vivo de TNF- $\alpha$ nos animais KO e WT, analisando comparativamente: 
1. a gravidade de infecção pulmonar e disseminação para fígado e baço através da quantificação de fungos viáveis pela técnica de Unidades Formadoras de Colônias (UFC) nas fases aguda e crônica;

2. a presença de citocinas proinflamatórias e anti-inflamatórias nos homogenatos de pulmão e fígado de animais KO e WT depletados de TNF- $\alpha$ e não depletados;

3. ao infiltrado celular nos pulmões de animais KO e WT tratados com anti-TNF- $\alpha$ e seus grupos controle IgG normal;

4. a histologia das lesões pulmonares de animais KO e WT depletados e não depletados;

5. a sobrevida média dos animais KO e WT após depleção de TNF- $\alpha$ e seu grupo controle IgG normal. 


\section{MATERIAL E MÉTODOS}

\subsection{ANIMAIS}

Camundongos da linhagem C57BL/6 nocautes para o gene da NO-sintase induzida (iNOS) ou NOSII foram originalmente adquiridos da Jackson Laboratory e estão sendo reproduzidos em condições SPF ("Specific Pathogen Free”) no Biotério do Departamento de Imunologia do ICB-USP. Camundongos controle, C57BL/6 normais, já são rotineiramente criados em nosso biotério.

\subsection{Paracoccidioides brasiliensis}

Foi utilizado o isolado $\mathrm{Pb} 18$ (virulento) do P. brasiliensis (KAHINO et al., 1985; SINGER-VERMES et al., 1989). A perda de virulência foi evitada renovando-se periodicamente a amostra $\mathrm{Pb} 18$. Novas amostras do fungo foram obtidas e reisoladas após passagens sucessivas em camundongos B10.A machos (suscetíveis) após 3 meses de infecção.

O fungo foi mantido, por repiques semanais, em meio semi-sólido de Fava Netto (FAVA NETTO, 1955) a $36^{\circ} \mathrm{C}$.

Para a realização das inoculações nos animais de ambas as linhagens, as células fúngicas foram obtidas após 1 semana de cultivo, e lavadas 3 vezes em PBS estéril. A suspensão mais leve, que contém células isoladas ou com poucos brotamentos, foi coletada. A concentração celular $\left(20 \times 10^{6}\right.$ células/mL) foi ajustada tomando-se por base a contagem em câmara de Neubauer e a determinação da viabilidade da suspensão (corante vital Verde-Janus B - BERLINER e RECA, 1966).

\subsection{INFECÇÃO DOS CAMUNDONGOS}

Grupos ( $n=5-6)$ de animais da linhagem KO e seus respectivos controles normais foram infectados pela via intratraqueal (i.t.) com $50 \mu \mathrm{L}$ de uma suspensão de $20 \times 10^{6}$ células leveduriformes do fungo/mL de PBS ( 1 x $10^{6}$ células). 
O procedimento foi realizado com os animais sob anestesia seguindo o esquema: 1) administração de $10 \mathrm{~mL} / \mathrm{kg}$ de peso de solução de cloridrato de 2-(2,6-xilidino) 5,6 dihidro4H-1,3-tiazina (ROMPUN, Bayer do Brasil) a 0,4\% pela via i.p. (0,2 mL de Rompun); 2) após 10 minutos, administração de $10 \mathrm{~mL} / \mathrm{kg}$ de peso de hidrato de cloral (Reagen do Brasil) a 2,5\% pela via i.p. $(0,2 \mathrm{~mL}$ de Hidrato de Cloral).

Quando o animal apresenta-se insensível à dor (após 10 minutos), foi feita uma pequena incisão longitudinal na pele do pescoço, e a traquéia exposta. Após a inoculação, a incisão foi suturada e os animais colocados sob fonte moderada de calor para controlar a hipotermia transitória produzida pela anestesia.

Os animais foram avaliados quanto:

- a gravidade da doença pela quantificação de fungos viáveis pela técnica de Unidades Formadoras de Colônias- UFC de pulmão, fígado e baço nas 2, 6 e 10 semanas de infecção;

a presença de citocinas pulmonares de animais iNOS KO e WT nas 2 e 10 semanas de infecção;

- ao estudo da atividade fungicida de macrófagos alveolares de animais infectados, após 2 e 10 semanas de infecção, através da obtenção do Lavado Bronco Alveolar;

- ao infiltrado celular (linfócitos e macrófagos dos pulmões), pela análise do fenótipo celular por citometria de fluxo em camundongos $\mathrm{KO}$ e seus controles WT normais infectados pelo P. brasilienis;

- $\quad$ ao efeito da depleção da citocina próinflamatória TNF- $\alpha$, no número de fungos viáveis recuperados após 2 e 8 semanas de infecção -UFC-, e na sobrevida dos camundongos infectados. Na segunda semana de infecção foi analisado o infiltrado celular pulmonar e os níveis de citocinas pulmonares e hepáticas de animais KO e WT depletados de TNF- $\alpha$ e seu grupo controle (IgG normal);

- a histopatologia das lesões dos pulmonares de animais KO e WT infectados e tratados com anti-TNF- $\alpha$ e seu grupo controle IgG normal na oitava semana de infecção;

- ao efeito da depleção de linfócitos $\mathrm{T} \mathrm{CD}^{+}$, em ambas as linhagens de camundongos, no número de UFC e infiltrado celular pulmonar na segunda semana de infecção. 


\subsection{DETERMINAÇÃO DO NÚMERO DE UNIDADES FORMADORAS DE COLÔNIA (UFC) IN VIVO}

Após 2, 6 e 10 semanas de infecção i.t., os camundongos iNOS KO e seu grupo controle "wide type" WT foram sacrificados e um dos pulmões, um lóbulo do fígado e parte do baço foram separados, pesados, e macerados em $5 \mathrm{~mL}$ de PBS com o uso de homogenizadores. $\mathrm{O}$ macerado dos órgãos foi submetido à centrifugação, 10 minutos, $750 \mathrm{xg}$ a $4{ }^{\circ} \mathrm{C}$ e o sedimento final retomado em um volume de $1 \mathrm{~mL}$ de PBS. Uma alíquota de $100 \mu \mathrm{L}$ dessa suspensão e de suas diluições foi semeada em placas de Petri com meio de cultura adequado. A incubação foi feita a $35{ }^{\circ} \mathrm{C}$ e o crescimento das colônias de $P$. brasiliensis foi acompanhado e registrado diariamente por um período médio de 15 dias.

O meio de cultura empregado foi constituído de BHI-ágar ("Brain Heart Infusion") suplementado com 5\% de "fator de crescimento do fungo" e $4 \%$ de soro eqüino (SINGERVERMES et al., 1993). Vale frisar que apenas um dos pulmões foi utilizado para a determinação de UFC e no sobrenadante do macerado deste foram quantificadas as citocinas (IL-12, TNF- $\alpha$, IL-2 e IFN- $\gamma$ - tipo 1 e inflamatórias e IL-4, IL-5, IL-10 e TGF- $\beta$ tipo 2). A outra metade dos pulmões foi reservada para estudos histopatológicos. O UFC foi também realizado em animais KO e WT tratados com anti-TNF- $\alpha$ e anti-CD8, bem como seus grupos IgG normal, após 2 semanas de infecção e 8 semanas para os animais tratados com anti-TNF$\alpha$.

\subsection{DOSAGEM DE CITOCINAS}

A dosagem de citocinas foi realizada no sobrenadante do macerado de pulmão utilizado na determinação de UFC nas segunda e décima semanas de infecção de animais KO e WT. O sobrenadante do macerado de pulmão e fígado de animais KO e WT tratados com anti-TNF- $\alpha$ e seu grupo IgG normal também foi obtido para a dosagem de citocinas proinflamatórias (TNF- $\alpha$, IFN- $\gamma$, IL-12) e anti-inflamatórias (IL-10 e TGF- $\beta$ ) na segunda semana de infecção. Os sobrenadantes dos macerados dos pulmões-os homogenatos-foram separados, aliquotados a $1 \mathrm{~mL}$ e mantidos a $-70^{\circ} \mathrm{C}$ até o momento da dosagem das citocinas.

A presença e concentração das citocinas foram determinadas por testes de ELISA de captura, segundo metodologia descrita para o nosso modelo (CANO et al., 1998, 2000). Estes 
ensaios foram baseados na utilização de pares de anticorpos monoclonais (AcM) específicos para cada citocina, um dos quais marcado por biotina.

As concentrações para cada um dos AcM primário e secundário foram previamente determinadas em nosso laboratório.

As placas de fundo chato $\left(\operatorname{COSTAR}^{\circledR}\right)$ foram sensibilizadas com o AcM primário diluído em solução de fosfato de sódio pH 6,0 (para as citocinas IL-10 e TNF- $\alpha$ ) e pH 9,0 (para as demais citocinas) na concentração indicada e incubadas por 24 horas a $4{ }^{\circ} \mathrm{C}$.

Os sítios livres foram bloqueados com gelatina a 1,5\% em PBS, pH 7,0 e incubados por 2 horas à temperatura ambiente. A citocina recombinante seguindo uma diluição seriada em $10 \%$ de SFB (Soro Fetal Bovino) para a obtenção da curva-padrão prosseguindo-se a adição das amostras em duplicata nos demais poços.

Após aproximadamente 18 horas de incubação a $4{ }^{\circ} \mathrm{C}$ foi adicionado às placas o $\mathrm{AcM}$ secundário biotinilado, na concentração desejada, e diluído previamente em PBS com 10\% de SFB seguindo-se incubação por 45 minutos à temperatura ambiente.

O complexo estreptoavidina-biotina-peroxidase foi diluído em tampão PBS/T20 e incubado às placas por 30 minutos. A reação com o substrato constituído de $5 \mu \mathrm{L}$ de $\mathrm{H}_{2} \mathrm{O}_{2}$ a $30 \%$ diluído em solução composta por $2,8 \mathrm{~mL}$ de tampão fosfato de sódio $0,2 \mathrm{M}, 2,2 \mathrm{~mL}$ de ácido cítrico $0,1 \mathrm{M}, \mathrm{pH} 5,0$ e de $10 \mathrm{~mL}$ de $\mathrm{H}_{2} \mathrm{O}$, adicionado de $10 \mathrm{mg}$ de ortofenilenodiamina (OPD). As placas foram incubadas por 45 minutos ao abrigo da luz em temperatura ambiente e a reação foi interrompida com a adição de ácido sulfúrico $4 \mathrm{~N}$.

A leitura das densidades ópticas foi feita a $492 \mathrm{~nm}$. As concentrações de cada citocina foram determinadas tendo como base a reta de regressão linear obtida com os dados referentes às diluições das citocinas recombinantes (curva-padrão).

\subsection{LAVADO BRONCO-ALVEOLAR}

Os animais KO e seu grupo WT, após 2 e 10 semanas de infecção pelo P. brasiliensis, foram submetidos ao processo de obtenção de lavado bronco-alveolar (LBA), segundo a metodologia descrita por Sugar et al. (1983). Os animais foram sacrificados e dissecados, a cavidade toráxica aberta e a traquéia cateterizada. Os pulmões foram então lavados com injeções de 1 ou 1,5 mL de meio “Dulbelcco's Modified Eagle's Medium” pH 6,8 (DME, Sigma $^{\circledR}$ ). O número total de células do LBA foi determinado por contagem em câmara de 
Neubauer após a mistura de $10 \mu \mathrm{L}$ da suspensão celular a $90 \mu \mathrm{L}$ de cristal violeta $0,05 \%$ em ácido acético a 30\%. Os resultados foram expressos em valores absolutos do número de células/animal.

As células foram ajustadas para $4 \times 10^{5} / \mathrm{mL}$ em cada placa de cultura. Um volume de $0,05 \mathrm{~mL}$ de células foi dispensado em cada orifício de placas de cultivo de 24 poços $\left(\right.$ Costar $^{\circledR}$, Cambridge, Mass). As culturas foram incubadas a $37{ }^{\circ} \mathrm{C}$ em $5 \%$ de $\mathrm{CO}_{2}$ por 2 horas. As células não aderentes foram removidas por aspiração, a monocamada aderente lavada com meio DME.

\subsubsection{TRATAMENTO DE CULTURAS DE MACRÓFAGOS}

As monocamadas de macrófagos $(\mathrm{M} \varnothing)$ alveolares foram incubadas durante a noite a $37{ }^{\circ} \mathrm{C}$ em $5 \%$ de $\mathrm{CO}_{2}$ tratadas previamente com meio DME (pH 6,8) contendo antibióticos, glutamina e $10 \%$ de SFB (Soro Fetal Bovino), com ou sem o tratamento de IFN $\gamma$ Pharmingen ${ }^{\circledR}(10.000 \mathrm{pg} / \mathrm{mL})$.

\subsubsection{INFECÇÃO DOS MACRÓFAGOS ALVEOLARES}

Os macrófagos foram infectados com a suspensão de leveduras na relação $\mathrm{Pb} / \mathrm{M} \emptyset$ de 1:50 por um período de 48 horas a $37^{\circ} \mathrm{C}$ em $5 \%$ de $\mathrm{CO}_{2}$ em meio suplementado com ou sem o tratamento de IFN- $\gamma$. Após esse período de incubação, os sobrenadantes foram retirados e armazenados a $-70{ }^{\circ} \mathrm{C}$ para a determinação de $\mathrm{NO}$ e os fungos que não foram aderidos ou fagocitados foram recolhidos por 2 lavagens com meio DME $(0,2 \mathrm{~mL})$.

\subsubsection{DETERMINAÇÃO DE UNIDADES FORMADORAS DE COLÔNIAS (UFC)}

Depois da incubação das culturas a $37{ }^{\circ} \mathrm{C}$ em $5 \%$ de $\mathrm{CO}_{2}$ por 48 horas, as células em suspensão foram colhidas por aspiração e as células aderentes lavadas com água destilada estéril para que ocorresse a lise dos $\mathrm{M} \emptyset$. O homogenato de cada lavagem foi recolhido até completar um volume de $1 \mathrm{~mL}$ para cada orifício. Este material foi centrigugado por 10 minutos, a $750 \mathrm{xg}$, a $4{ }^{\circ} \mathrm{C}$ e ressuspenso em volume adequado de DME simples. O 
sobrenadante foi desprezado, o sedimento foi ressuspenso em $1 \mathrm{~mL}$ de PBS e a suspensão obtida foi plaqueada (100 $\mu \mathrm{L} /$ placa) em meio BHI suplementado para recuperação de $\mathrm{Pb}$ viáveis. As placas foram incubadas a $37{ }^{\circ} \mathrm{C}$ e as colônias contadas diariamente até que nenhum aumento de UFC fosse observado.

\subsection{DETERMINAÇÃO DA PRODUÇÃO DE NO}

A concentração de NO nos sobrenadantes de culturas foi medida com o reagente de Griess (1\% sulfanilamida, $0,1 \%$ diidrocloreto de naftiletilenodiamina, 2,5\% $\left.\mathrm{H}_{3} \mathrm{PO}_{4}\right)$. Um volume de $50 \mu \mathrm{L}$ do sobrenadante da cultura foi adicionado a um volume igual ao reagente de Griess, depois de incubado em temperatura ambiente por 10 minutos, foi determinada a absorbância em equipamento de leitor de ELISA em comprimento de $550 \mathrm{~nm}$. A concentração de NO foi determinada usando a curva padronizada com diferentes concentrações de nitrito de sódio $\left(\mathrm{NaNO}_{2}\right)$ (DING et al., 1988). Todas as dosagens foram expressas em micromolar de $\mathrm{NO}_{2}$.

\subsection{DETERMINAÇÃO DA PRODUÇÃO DE $\mathrm{H}_{2} \mathrm{O}_{2}$}

A liberação de $\mathrm{H}_{2} \mathrm{O}_{2}$ de macrófagos alveolares obtidos do lavado bronco-alveolar de animais KO e WT foi avaliada pelo ensaio de oxidação da peroxidade dependente de fenol vermelho descrito por Pick e Mizel (1981). Este método é baseado na conversão do phenol red (phenolsulfonphthalein PSP) por peróxido de hidrogênio na presença de peroxidase (Horseradish peroxidase) em um composto colorido. Um volume de $100 \mu \mathrm{L}$ do LBA, com ou sem $10 \mu \mathrm{L}$ de PMA ("Phorbol 12-myristane 13-acetate", ativador celular) contendo $2 \times 10^{5}$ células foi diluído em tampão fenol red contendo $50 \mu \mathrm{g} / \mathrm{mL}$ de peroxidase (tipo II) e incubado em placa de cultivo de 24 poços $\left(\operatorname{Costar}^{\circledR}\right)$ por $1 \mathrm{~h}$ em câmara úmida a $5 \%$ de $\mathrm{CO}_{2}$ a $37{ }^{\circ} \mathrm{C}$. A reação foi interrompida pela adição de $10 \mu \mathrm{L}$ de $1 \mathrm{~N}$ de $\mathrm{NaOH}$ e a absorbância determinada pelo leitor de ELISA em comprimento de $620 \mathrm{~nm}$. A concentração de $\mathrm{H}_{2} \mathrm{O}_{2}$ foi determinada usando a curva padronizada com diferentes concentrações em quadruplicata de fenol red e expressas em micromolar de $\mathrm{H}_{2} \mathrm{O}_{2}$. 


\subsection{OBTENÇÃO DE LINFÓCITOS INFILTRANTES DE PULMÃO}

Células dos pulmões de camundongos KO e WT foram obtidas nas segunda e décima semanas após infecção. Para os animais KO e WT tratados com anti-TNF- $\alpha$ e anti-CD8, e seus controles IgG, a obtenção de células pulmonares foi feita após 2 semanas de infecção. Os pulmões de cada animal ( $n=5$ de cada grupo, iNOS KO e iNOS normais) foram colocados em solução de colagenase $(1 \mathrm{mg} / \mathrm{mL})$ e DNase $(30 \mu \mathrm{g} / \mathrm{mL})$ em meio RPMI suplementado (SFB, $5 \%$ ) em agitação a $37{ }^{\circ} \mathrm{C}$ por 1 hora. Posteriormente cada órgão foi transferido para tubo contendo $5 \mathrm{~mL}$ de RPMI + 5\% SFB, macerado e centrifugado a $1000 \mathrm{rpm}, 10 \mathrm{~min}$. O precipitado foi ressuspenso em $5 \mathrm{~mL}$ de PERCOL 20\% para se proceder à centrifugação (1500 x g por 30 min.) e separação dos linfócitos de debris e de células epiteliais (LINDELL et al., 2006). Os eritrócitos foram lisados com solução de $9 \mathrm{~mL} \mathrm{NH} \mathrm{N}_{4} \mathrm{Cl}$ e $1 \mathrm{~mL}$ TRIS. A viabilidade celular (feita com trypam blue 0,4\%) acima de $85 \%$, ajustou-se a concentração celular para $1 \times 10^{6}$ células, e em seguida as células foram lavadas para marcação posterior com os anticorpos marcados (para citometria de fluxo). Procedeu-se a incubação por 20 min em $4{ }^{\circ} \mathrm{C}$ no escuro. Em seguida as amostras foram fixadas em $2 \%$ de paraformaldeído, armazenadas a $4{ }^{\circ} \mathrm{C}$ no escuro até análise por citometria de fluxo.

\subsection{CITOMETRIA DE FLUXO PARA CARACTERIZAÇÃo DE SUB- POPULAÇÕES DE LINFÓCITOS E MONÓCITOS}

As células marcadas, após incubação por 20 min em $4{ }^{\circ} \mathrm{C}$ no escuro e fixadas com $2 \%$ de paraformoldeído (na concentração de $1 \times 10^{6}$ ), foram analisadas em citômetro de fluxo FACSCalibur® (Becton-Dickison). Foram usados anticorpos marcados com isotiocinado de fluoresceína (FITC), ficoeritrina (PE) ou outro fluorocromo Cy-Chrome (Cy) na combinação adequada para a análise da população celular em estudo.

Todos os anticorpos (BD Bioscience Pharmingen ${ }^{\circledR}$ ) foram usados na diluição $1 / 100 \mu \mathrm{L}$ (FITC anti-CD4, FITC anti-CD8, PE anti-CD25, PE anti CD69, PE anti-CD80, PE antiCD86, PE anti-CD40, FITC anti-Ia ${ }^{\mathrm{b}}$, FITC anti-CD11b, PE-anti CD11c). A aquisição das células (no mínimo de 10.000 eventos) foi feita em aparelho FACS Calibur (BD Pharmingen ${ }^{\circledR}$ ) e análise pelo software Cell-Quest software (BD Pharmingen ${ }^{\circledR}$ ). Foram feitos "gates" individuais para linfócitos e "gates" para macrófagos durante a análise no FACS Calibur. Para a caracterização fenotípica de macrófagos e de células dendríticas, foram feitos 
"gates" para macrófagos $\mathrm{CD} 11 \mathrm{~b}^{\text {high }} \mathrm{CD} 80^{\text {high }}$ e "gates" para células dendríticas CD11c ${ }^{\text {high }}$ CD86 $^{\text {high }}$ (SCREIBER et al., 2008). As populações celulares foram caracterizadas quanto à porcentagem (\%) de cada sub-população multiplicada pelo valor absoluto, calculado em função do número de células totais obtido pela contagem prévia das suspensões celulares em câmera de Neubauer.

\subsection{CITOMETRIA DE FLUXO PARA CARACTERIZAÇÃo DE CÉluLAS T REGULADORAS TCD4 ${ }^{+} \mathrm{CD}^{+} 5^{+}$ATRAVÉS DA EXPRESSÃO DO FATOR DE TRANSCRIÇÃO FOXP3}

Após a obtenção de suspensão contendo 1 x $10^{6}$ células $/ \mathrm{mL}$, procedeu-se a marcação de proteínas de membrana com anti-CD4 PE (1/100) e de anti-CD25 FITC (1/100), por 30 minutos em temperatura a $4{ }^{\circ} \mathrm{C}$. Posteriormente, as células foram lavadas com tampão de coloração ("staining buffer") contendo $2 \%$ de soro fetal bovino, $0,1 \%$ de azida, $100 \mathrm{~mL}$ de PBS (1x). A seguir, foi feita a permeabilização da membrana plasmática com a adição de 200 $\mu \mathrm{L} /$ poço de Cytofix/Cytoperm ("Fixation/Permeabilization" Kit BD Bioscienes ${ }^{\circledR}$ ) em temperatura ambiente por 30 minutos, protegido da luz. Após a lavagem das células, realizouse a permeabilização da membrana nuclear com a utilização de $130 \mu \mathrm{L} /$ poço de solução contendo $750 \mu \mathrm{L}$ de PBS $1 \mathrm{x}, 250 \mu \mathrm{L}$ de paraformoldeído $4 \%, 5 \mu \mathrm{L}$ de Tween 20 Sigma $^{\circledR}$ e as células, então, foram encubadas por 30 minutos em temperatura ambiente no escuro.

Após lavagem das células com PBS (1x) gelado, prosseguiu-se a marcação com o anticorpo para o fator de transcrição nuclear FoxP 3, Cy, diluído a 1/50 em tampão de coloração. As células foram incubadas por $1,5 \mathrm{~h}$ a $4{ }^{\circ} \mathrm{C}$, posteriormente lavadas com PBS gelado e fixadas com $2 \%$ de paraformaldeído, armazenadas a $4{ }^{\circ} \mathrm{C}$ no escuro até a análise por citometria de fluxo. Foram feitos os "gates" primeiramente para linfócitos totais, depois para linfócitos $\mathrm{T} \mathrm{CD}^{+}$, linfócitos $\mathrm{T} \mathrm{CD}^{+} \mathrm{CD} 25^{+}$e finalmente, o gate para linfócitos $\mathrm{T}$ $\mathrm{CD} 4^{+} \mathrm{CD} 25^{+} \mathrm{Fox} \mathrm{P} 3^{+}$.

A aquisição das células (100.000 eventos) foi feita pelo FACS Calibur (BD Pharmingen ${ }^{\circledR}$ ) utilizando o software Cell-Quest software (BD Pharmingen ${ }^{\circledR}$ ). O número de células $\mathrm{T}$ reg $\left(\mathrm{T} \mathrm{CD} 4^{+} \mathrm{CD} 25^{+} \mathrm{FoxP}^{+}\right)$foi apresentado pela porcentagem (\%) a partir do número de células $\mathrm{T} \mathrm{CD} 4^{+} \mathrm{CD} 25^{+}$obtido. 


\subsection{PRODUÇÃO E PURIFICAÇÃO DE ANTICORPOS MONOCLONAIS (AcM) EMPREGADOS NOS EXPERIMENTOS DE DEPLEÇÃO}

\subsubsection{HIBRIDOMA}

Foram utilizados os hibridomas MP6-XT22 (rat IgG1 anti-TNF- $\alpha$ ) e o H-35 (rat IgG1 anti-CD8) gentilmente cedidos pela Dra Ises Abrahamsohn (Universidade de São Paulo-ICBIV).

\subsubsection{EXPANSÃO DO HIBRIDOMA IN VITRO}

Inicialmente as células dos hibridomas MP6-XT22 e H-35 foram mantidas por cultivo in vitro utilizando o meio de cultura RPMI-1640 $\left(\right.$ Gibco $\left.^{\circledR}\right)$ suplementado com $10 \%$ de soro fetal bovino, 2-mercaptoetanol $0,05 \mathrm{Mm}$, glutamina $2 \mathrm{mM}$, penicilina $100 \mathrm{UL} / \mathrm{mL}$ e estreptomicina $100 \mu \mathrm{g} / \mathrm{mL}$. As células do hibridoma foram incubadas a $37{ }^{\circ} \mathrm{C}$, em estufa contendo $5 \%$ de $\mathrm{CO}_{2}$, em atmosfera úmida, e repicadas a cada 48 horas. As células foram ressuspensas em meio fresco, determinado seu número total e sua viabilidade pela contagem, em câmera de Neubauer, após a mistura de $20 \mu \mathrm{L}$ da suspensão celular com $180 \mu \mathrm{L}$ de Azul de Trypan $(0,4 \%)$.

Quando o número e a viabilidade das células forem adequados, parte das mesmas foi colocada em meio RPMI 1640 contendo $20 \%$ de soro fetal bovino e $10 \%$ de DimethylSulfoxide (DMSO), rapidamente congelada a $-70{ }^{\circ} \mathrm{C}$ (48 horas) e posteriormente foi estocada em nitrogênio líquido.

\subsubsection{EXPANSÃO DO HIBRIDOMA IN VIVO}

Os hibridomas desenvolvem-se muito bem na cavidade peritoneal de animais BALB/c geneticamente atímicos (nu/nu). Sete animais foram pré-tratados (dia -1) com $1 \mathrm{~mL}$ de Pristane (2,6,10,14-tetra-methyl-pentadecane, Sigma® ${ }^{\circledR}$ T-7640) pela via intraperitoneal (i.p.). Após 24 horas os animais foram inoculados pela via i.p. 5 × $10^{6}$ células viáveis de cada hibridoma (MP6-XT22 e H-35). 
Os animais inoculados desenvolveram ascite evidente antes do décimo quinto dia. Estes foram então sacrificados, a cavidade peritoneal dissecada e retirado todo o líquido ascítico. Este líquido foi centrifugado a $270 \mathrm{x} \mathrm{g}$, a $4{ }^{\circ} \mathrm{C}$ por 10 minutos, e o sobrenadante (com os AcM) estocado a $-20^{\circ} \mathrm{C}$ para posterior purificação dos anticorpos presentes.

\subsubsection{PRECIPITAÇÃO E PURIFICAÇÃO DOS ANTICORPOS MONOCLONAIS}

Após a expansão dos AcM (in vivo) estes foram precipitados utilizando o método descrito por Mckinney e Parkison (1987). O material ascítico foi diluído 1:5 em tampão acetato $60 \mathrm{Mm}, \mathrm{pH}$ 4,0, o pH da solução foi ajustado para 4,5 com $\mathrm{NaOH}$ 1N. Posteriormente foram adicionados, gota a gota, $25 \mu \mathrm{L}$ de ácido caprílico para cada $1 \mathrm{~mL}$ de solução; a mistura foi deixada em repouso por 30 minutos e posteriormente centrifugada a $10000 \mathrm{x} \mathrm{g}$, a $4{ }^{\circ} \mathrm{C}$, por 30 minutos; foi coletado o sobrenadante e determinado o volume obtido; em seguida foi adicionado $1 \mathrm{~mL}$ de tampão PBS/EDTA $2 \mathrm{mM}$ (10x) para cada $10 \mathrm{~mL}$ do sobrenadante e o $\mathrm{pH}$ ajustado para 7,4 com $\mathrm{NaOH} 1 \mathrm{~N}$. A solução foi esfriada a $4{ }^{\circ} \mathrm{C}$ e adicionado sulfato de amônio até obter-se $45 \%$ de saturação, prosseguindo-se com a agitação por 30 minutos. A preparação foi centrifugada a $10000 \mathrm{x} \mathrm{g}$, a $4{ }^{\circ} \mathrm{C}$, por 30 minutos, separando-se o precipitado (o sobrenadante será reservado até ter-se a certeza de que os anticorpos estavam no precipitado) que foi dissolvido em pequeno volume de tampão PBS/EDTA (uma vez concentrado); a solução foi dializada contra PBS/EDTA durante 72 horas (com três trocas diárias); foi depois aquecida a $50-55^{\circ} \mathrm{C}$ por 20 minutos e centrifugada a $5000 \mathrm{x}$ g por 20 minutos. O sobrenadante foi coletado, determinado seu volume, assim como também o conteúdo de proteínas (método do ácido bicinonínico-BCA). Todo o material foi filtrado em membrana Millipore $(0,22 \mu \mathrm{L}$ aliquotado) e estocado a $-20{ }^{\circ} \mathrm{C}$.

\subsubsection{DOSAGEM DE PROTEÍNAS (MÉTODO DO ÁCIDO BICINCONÍNICO, BCA)}

A dosagem de proteínas totais presentes nos AcM precipitados foi realizada pelo método colorimétrico do ácido bicinconínico (Pierce, N/c 23225, BCA protein assay reagent), segundo as instruções do fabricante. 


\subsubsection{ANÁLISE DO GRAU DE PUREZA DAS AMOSTRAS POR SDS-PAGE}

Para verificar o grau de pureza dos AcM precipitados foi realizada eletroforese em gel de poliacrilamida a 12,5\% com posterior coloração pela prata, utilizando a metodologia automatizada do Phast-System TM (Pharmacia ${ }^{\circledR}$ LKB Biotechnology). Foram utilizados, como proteínas de referência, padrões protéicos de baixo peso molecular (Low Molecular Weight, LMW) fornecidos pela Pharmaciaß).

\subsubsection{PURIFICAÇÃO DE $\gamma$-GLOBULINA NORMAL DE RATO}

A IgG controle foi purificada a partir da mistura de soros obtidos de ratos Wistar adultos. O sangue foi obtido por punção cardíaca e posteriormente coletado o soro, o qual foi então submetido aos procedimentos de precipitação da IgG, dosagem de proteínas e SDSPAGE.

\subsubsection{DEPLEÇÃO DE TNF- $\alpha$}

Camundongos C57BL/6 iNOS KO (KO) e seu grupo C57BL/6 iNOS normais, (WT), foram depletados de TNF- $\alpha$ através da inoculação de $250 \mu \mathrm{g} / 0,5 \mathrm{~mL}$ i.p. do anticorpo monoclonal MP6-XT22 purificado. Este anticorpo foi aplicado 4 horas antes da inoculação i.t. de leveduras viáveis do $\mathrm{Pb}$ 18. Este tratamento foi repetido nos dias 6 e 12 após a infecção.

Os animais controle foram inoculados com IgG normal de rato nos mesmos dias e na mesma concentração protéica do anticorpo monoclonal. Após 2 e 8 semanas de infecção foi analisado o número de UFC (pulmão, fígado e baço) e o infiltrado celular por citometria de fluxo após 2 semanas de infecção.

\subsubsection{DEPLEÇÃO DE LINFÓCITOS T CD8}

Camundongos C57BL/6 iNOS KO (KO) e seu grupo C57BL/6 iNOS normais, (WT), foram depletados de linfócitos T CD8 através da inoculação pela via i.p. do anticorpo monoclonal H-35 purificado. Este anticorpo foi administrado na concentração de $200 \mu \mathrm{g} / 0,5$ 
mL 48 e 24 horas antes da inoculação i.t de leveduras viáveis do Pb18. Nos dias 6 e 12 pós infecção foram administrados $150 \mu \mathrm{g} / 0,5 \mathrm{~mL}$ deste anticorpo nos animais.

Os animais controle foram inoculados com IgG normal de rato nos mesmos dias e na mesma concentração proteica do anticorpo monoclonal. Após 2 semanas de infecção foi analisado o número de UFC (pulmão, fígado e baço) e o infiltrado celular por citometria de fluxo.

\subsection{DETERMINAÇÃO DO TEMPO MÉDIO DE SOBREVIDA DOS CAMUNDONGOS TRATADOS COM ANTI-TNF- $\alpha$}

Experimento inicial demonstrou uma mortalidade precoce dos animais infectados tratados com o anticorpo monoclonal anti-TNF- $\alpha$. Assim novos grupos foram formados e a mortalidade acompanhada até a décima semana pós-infecção, quando a maioria dos camundongos depletados de TNF- $\alpha$ havia morrido. A mortalidade dos animais foi acompanhada diariamente.

\subsection{ANÁLISE HISTOPATOLÓGICA DOS PULMÕES}

Foram examinados um dos pulmões de cada um dos animais tratados com anti-TNF- $\alpha$ e IgG normal na oitava semana de infecção. Animais KO e WT não infectados foram utilizados como controle adicional. Os órgãos foram preservados em formol Millonig modificado (CARSON et al., 1973) à temperatura ambiente até o momento do processamento. Posteriormente, já incluídos em parafina, foram cortados na espessura de 4 a $5 \mu \mathrm{m}$ e submetidos à coloração por hematoxilina-eosina (H\&E), para identificação celular, e impregnação pela prata metamina (Groccot), para melhor identificação da localização dos fungos no corte. O preparo das lâminas foi feito pelo Departamento de Imunologia do ICB IV e a análise descritiva das lesões foi realizada ao microscópio óptico comum pela Dra. Kátia Ramos Leite do Setor de Patologia Clínica do Hospital Sírio Libanês de São Paulo. 


\subsection{ANÁLISE ESTATÍSTICA}

Todos os experimentos realizados foram expressos como Média \pm Erro Padrão e as diferenças entre elas analisadas pelo teste $t$ de Student, método não pareado.

A análise de mortalidade foi feita pelo teste de Logrank (Graph Pad Prism v3Windows-Graph Pad Sofware). Resultados de $\mathrm{p}<0,05(*), \mathrm{p}<0,01(* *), \mathrm{p}<0,001(* * *)$ foram considerados significantes. 


\section{RESULTADOS}

\subsection{CARACTERIZAÇÃo DA GRAVIDAde DA DOENÇA E PRODUÇÃo DE CITOCINAS POR CAMUNDONGOS INOS KO E WT}

Os resultados apresentados são de experimentos realizados com a inoculação de $1 \mathrm{x}$ $10^{6}$ leveduras viáveis de $P$. brasiliensis por via intratraqueal (i.t.) e determinação de UFC nos tempos de 2, 6 e 10 semanas de infecção.

Grupos de animais C57BL/6 iNOS KO e C57BL/6 controle, WT, foram sacrificados nos tempos determinados após a inoculação do fungo. Um dos pulmões foi removido, pesado, macerado e plaqueado em ágar BHI suplementado. Durante 15 dias foi contado o número de colônias, e o número final foi transformado em $\log _{10} / \mathrm{g}$ de tecido.

Analisou-se a carga fúngica no sítio primário de infecção e a disseminação para fígado e baço. Os dados da figura 1A mostram que o pulmão de animais WT $\left(5,226 \pm 0,289 \log _{10}\right)$ apresenta aumento significante da carga fúngica comparada ao dos animais $\mathrm{KO}(4,554 \pm$ $\left.0,861 \log _{10}\right)(* \mathrm{P}=0,03)$.

Observou-se disseminação para o fígado e baço dos grupos WT e KO não havendo, entretanto, diferenças estatisticamente significantes (Figura 1A). Pelos dados obtidos neste experimento, verificamos que, no período de 2 semanas de infecção, a ausência da enzima NO-sintase induzida parece proteger os animais infectados pelo $P$. brasiliensis.

Os sobrenadantes de pulmões, obtidos durante o experimento para a quantificação de UFC, foram conservados a $-70^{\circ} \mathrm{C}$ e utilizados para a pesquisa de citocinas em animais $\mathrm{KO}$ e seu grupo controle WT nas segunda e décima semanas de infecção.

Os resultados obtidos em $\mathrm{pg} / \mathrm{mL}$ e expressos em média \pm erro padrão estão apresentados nas figuras $1 \mathrm{~B}$ e $1 \mathrm{E}$.

Nesta análise, somente a citocina TNF- $\alpha$ apresentou-se em níveis mais elevados no sobrenadante de pulmão de animais iNOS KO (WT: 1656,14 $\pm 445,81$ pg/mL e KO: 5976,68 $\pm 1954,3 \mathrm{pg} / \mathrm{mL}$ ) do que no grupo WT (Figura 1B). Assim, a menor carga fúngica nos pulmões dos animais deficientes de NO, concomitante com o aumento dos níveis da citocina próinflamatória TNF- $\alpha$ pulmonar, parecem proteger esses animais deficientes de NO durante a fase aguda da doença. 
No período de 6 semanas de infecção foi também analisado a carga fúngica dos órgãos de ambas as linhagens e verificamos que neste momento da doença a carga fúngica pulmonar de animais KO é equivalente a dos animais WT. Houve disseminação para fígado e baço entre os dois grupos estudados sem diferença estatisticamente significante (Figura 1C).

Por outro lado, a figura 1D mostra que na fase crônica do nosso modelo, na décima semana de infecção, o número de UFC dos animais KO apresentou, inesperadamente, uma maior carga fúngica pulmonar com expressiva diferença estatística $(* * * \mathrm{P}=0,001)$. Verificamos aumento de UFC pulmonar nos camundongos KO $\left(5,998 \pm 0,796 \log _{10}\right)$ comparada ao grupo WT $(4,636 \pm 0,802 \log 10)$. Em relação ao fígado, os animais mostraram números muito semelhantes de UFC e o mesmo foi verificado para o baço. Os níveis de citocinas pulmonares próinflamatória e anti-inflamatórias apresentaram-se semelhantes para ambos os animais (Figura 1E). 

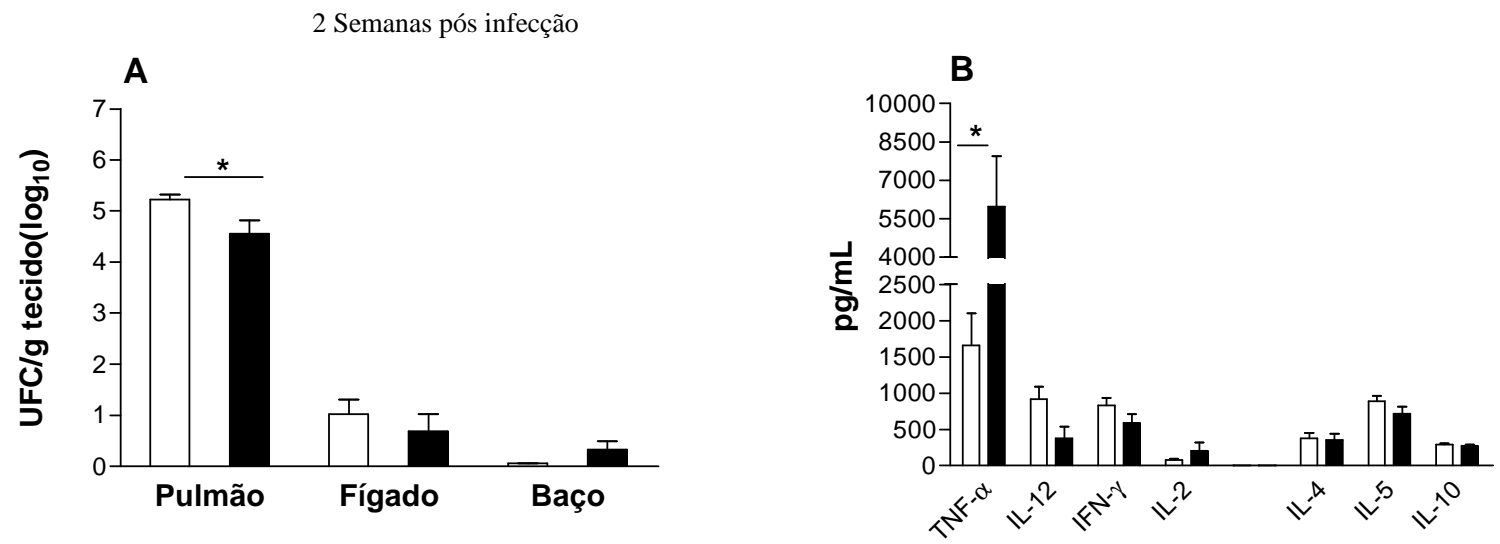

6 Semanas pós infecção

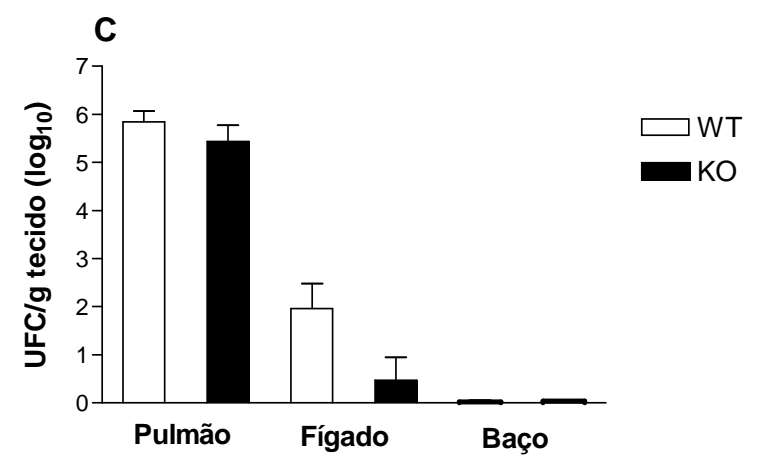

10 Semanas pós infecção
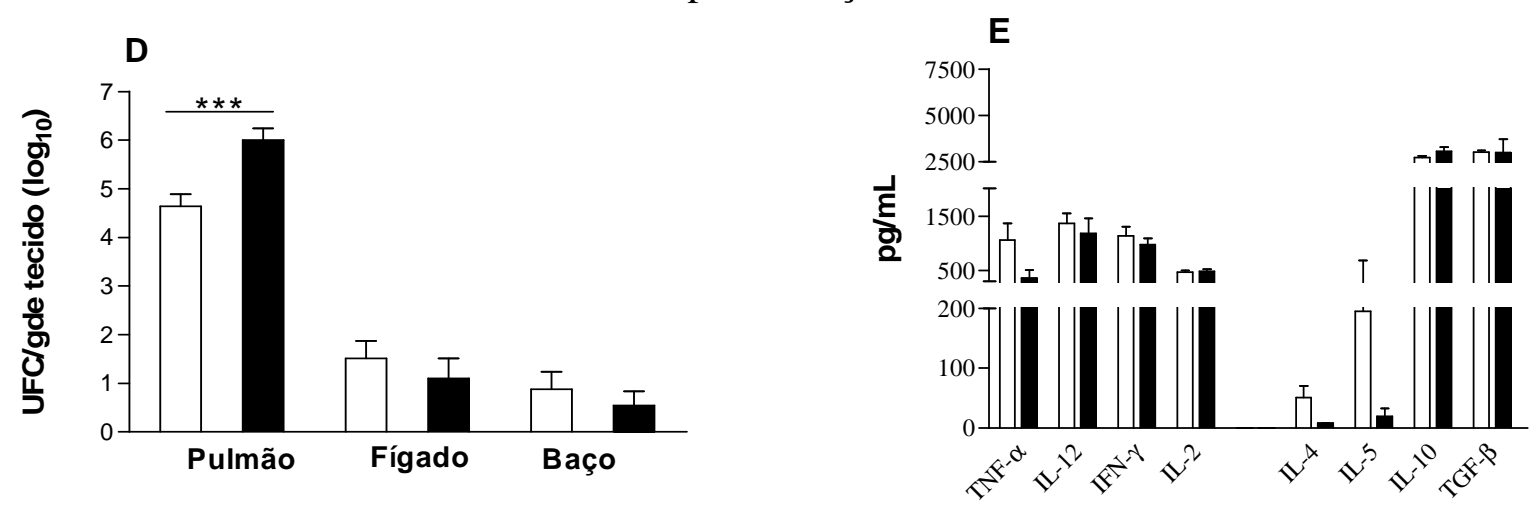

Figura 1. Avaliação da gravidade da doença por contagem do número de Unidades Formadoras de Colônias (UFC)/g de tecido (em log 10 ) em camundongos C57BL/6 iNOS KO (n=8) e C57BL/6, WT (n=8) após 2 (A), 6 (C) e 10 semanas (D) de infecção com 1 x $10^{6}$ leveduras de $P$. brasiliensis inoculadas pela via i.t. As barras apresentam as médias \pm EP dos grupos ensaiados. Resultado representativo de dois experimentos realizados com resultados equivalentes. Quantificação de citocinas presentes no sobrenadante de pulmão de animais C57BL/6 WT e C57BL/6 iNOS KO nas segunda e décima semanas após a infecção i.t. com o $P$. brasiliensis $(\mathrm{B}, \mathrm{E})$. $\mathrm{O}$ asterisco $(*)$ representa diferença estatisticamente significante $(* \mathrm{P}<0,05, * * * \mathrm{P}<0,001)$. 


\subsection{ESTUDO DA ATIVIDADE FUNGICIDA IN VITRO E DA PRODUÇÃO DE $\mathrm{H}_{2} \mathrm{O}_{2}$ E NO POR MACRÓFAgOS ALVEOLARES DE CAMUNDONGOS iNOS KO E SEU GRUPO CONTROLE APÓS 2 SEMANAS DE INFECÇÃO}

Para melhor caracterizarmos os estágios iniciais da infecção pelo $P$. brasilienis em animais iNOS deficientes e seu grupo controle WT, realizamos o estudo da atividade microbicida das células obtidas do lavado bronco alveolar (LBA) de ambas as linhagens de camundongos após 2 semanas de infecção. Foram determinados o número de fungos viáveis no LBA logo após a sua obtenção e após 48 h de cultivo das células aderentes, com ou sem a ativação pelo IFN- $\gamma(10.000 \mathrm{pg} / \mathrm{mL})$. Algumas culturas foram desafiadas com o P. brasiliensis na proporção de 1:50, $\mathrm{Pb}: \mathrm{M} \emptyset$, e estudadas 48 horas após.

Corroborando com os resultados obtidos com o número de UFC do homogenato pulmonar (Figura 1A), após 2 semanas de infecção, um menor número de células leveduriformes foi recuperado dos LBAs de animais iNOS KO comparado ao grupo controle WT (KO: $140 \pm 36,52$, WT: $1010 \pm 139,16$ fungos recuperados) (Figura 2A).

Devido aos resultados obtidos (Figura 2A), propusemo-nos a realizar o estudo de outro agente fungicida, que não fosse derivado do nitrogênio, que poderia explicar o menor número de fungos no LBA dos animais deficientes de NO. Deste modo, avaliamos a produção do peróxido de hidrogênio, um importante radical de oxigênio, formado durante o "burst" oxidativo de macrófagos alveolares. A Figura 2B mostra que tanto os macrófagos não estimulados (WT: 18,29 \pm 1,03, KO: 24,66 \pm 0,82 $\mu \mathrm{M}$ ) quanto os macrófagos estimulados com PMA (WT: $32,42 \pm 0,3$, KO: 46,33 $\pm 2,09 \mu \mathrm{M}$ ) de animais iNOS KO produzem níveis mais elevados de $\mathrm{H}_{2} \mathrm{O}_{2}$ comparado às células do grupo WT.

Quando os macrófagos foram ativados com IFN- $\gamma$, somente os macrófagos de animais WT, e não os de iNOS KO, apresentaram expressiva diminuição do número de fungos recuperados (WT: 921,67 \pm 196,7, WT+IFN- $\gamma:$ 122,5 \pm 17,97 fungos recuperados) em relação aos macrófagos não ativados. Além disso, concomitante com esse resultado, os macrófagos de animais WT ativados com IFN- $\gamma$ apresentaram maior produção de NO $(75,12 \pm 2,5 \mu \mathrm{M}) \mathrm{em}$ relação aos macrófagos não ativados $(5,5 \pm 0,35 \mu \mathrm{M})$ (Figuras $2 \mathrm{C}$ e $2 \mathrm{D}$, respectivamente).

Nas culturas de macrófagos, tratadas ou não com IFN- $\gamma$, que receberam um desafio adicional de leveduras de P. brasiliensis, após 48 horas de cultivo, foi caracterizado o número 
de UFC para ambos os grupos de animais estudados. Deste modo, uma elevada carga fúngica foi recuperada dos macrófagos de ambas as linhagens (Figura 2E). Quando o IFN- $\gamma$ foi adicionado às culturas, observamos mais ou vez uma maior atividade microbicida de macrófagos dos animais WT, (WT: $2325 \pm 343$, WT+ IFN- $\gamma: 435 \pm 39$ fungos recuperados), em relação aos macrófagos não ativados, o mesmo não tendo ocorrido com os animais iNOS $^{-/-}$ .Observou-se também maior produção de NO por macrófagos de animais WT quando ativados pela citocina (WT: 10,9 $\pm 1,39$, WT+IFN- $\gamma$ : 46,2 $\pm 4,38 \mu \mathrm{M}$ ) (Figuras $2 \mathrm{E}$ e $2 \mathrm{~F}$, respectivamente).

Pudemos observar então que, neste experimento de 2 semanas após infecção, os macrófagos alveolares dos LBAs de animais deficientes de NO apresentam menor carga fúngica, e que apesar da ausência na produção de NO, produziram níveis elevados de peróxido de hidrogênio que poderia ter sido responsável pela maior atividade fungicida destas células in vivo. Nossos resultados mostram ainda que somente macrófagos de animais normais para iNOS podem ser ativados por IFN- $\gamma$ o qual é responsável pela maior habilidade fungicida desses macrófagos. Estes dados também sugerem que a menor carga fúngica pulmonar dos camundongos iNOS-deficientes não pode ser atribuída à função dos macrófagos alveolares por mecanismo ativável por IFN- $\gamma$. Assim, outros mecanismos fungicidas, como a produção de $\mathrm{H}_{2} \mathrm{O}_{2}$, ou outros mecanismos microbicidas devem ser os responsáveis pelo maior controle do crescimento fúngico dos macrófagos de animais iNOS KO neste período de infecção. 
A
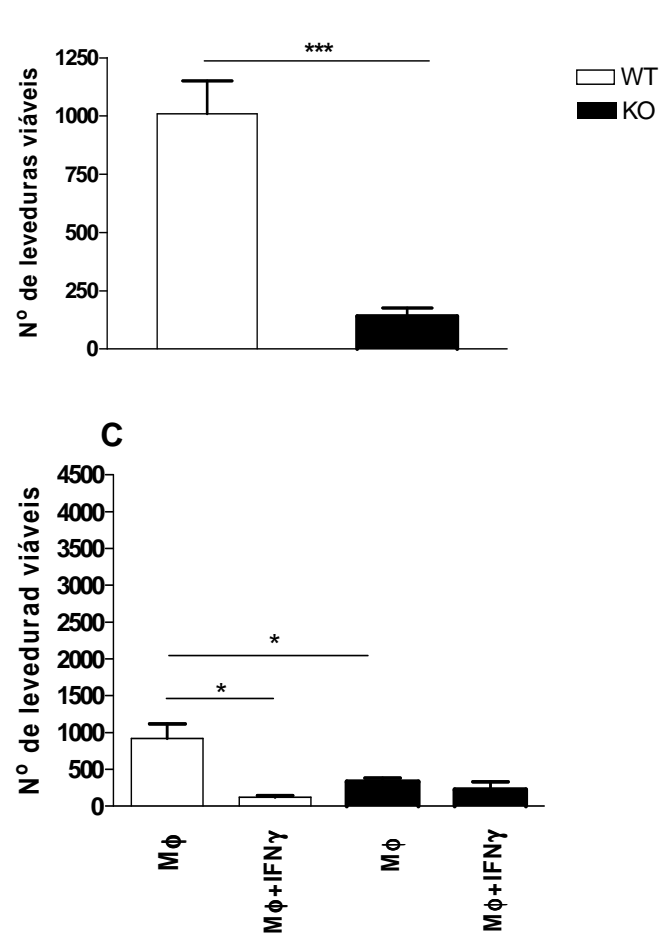

E

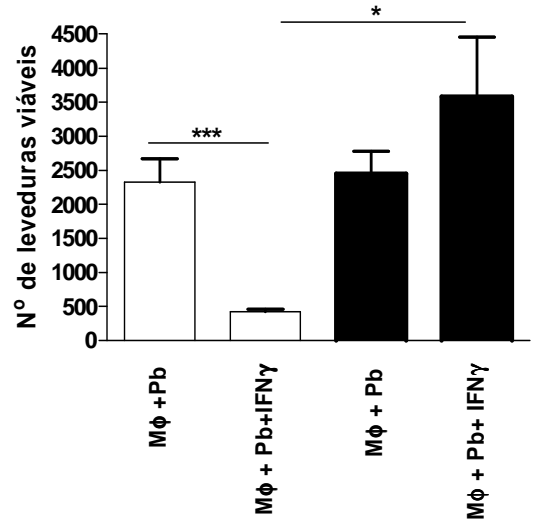

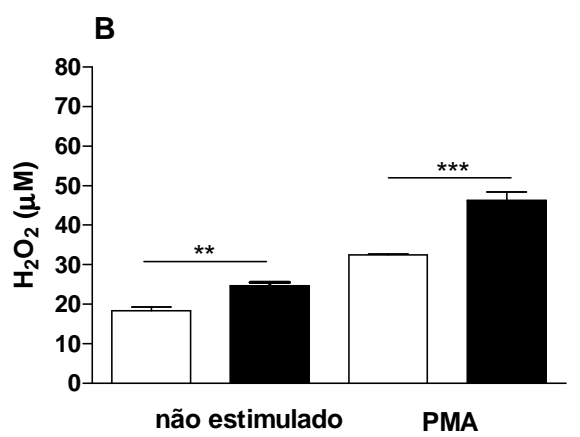
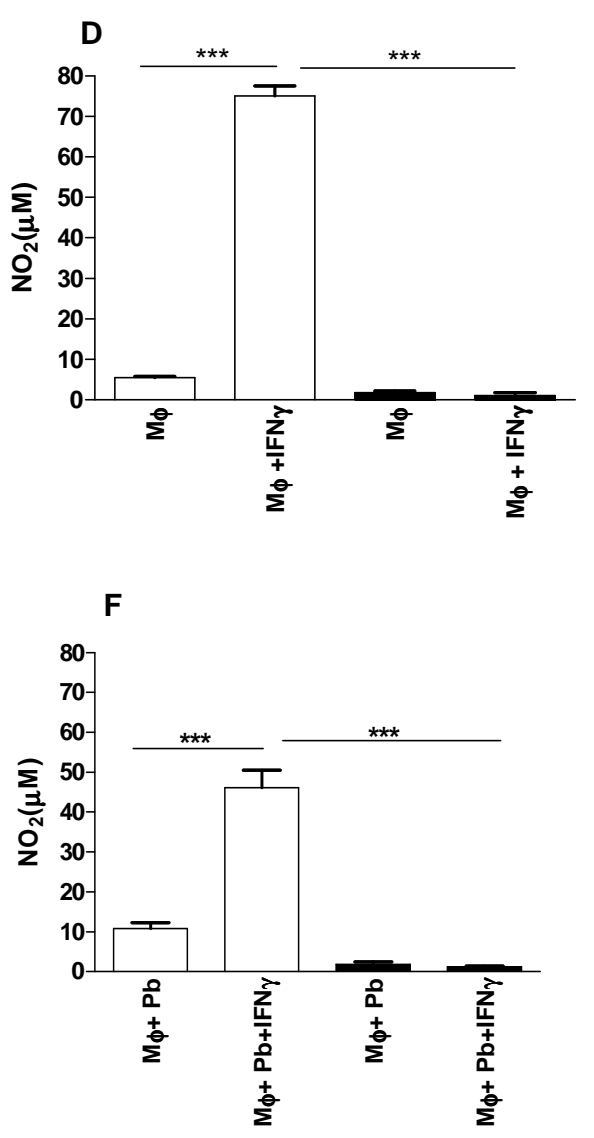

Figura 2. Na segunda semana de infecção, o lavado bronco alveolar (LBA) de animais iNOS KO possui uma menor carga fúngica, mas os macrófagos alveolares apresentam uma menor atividade fungicida. (A) Número de leveduras viáveis (número de UFC) recuperadas de LBAs de animais iNOS $^{-/}$e seu grupo "wild type" (WT) C57BL/6, 2 semanas após a infecção com 1 milhão de leveduras de $P$. brasiliensis. (B) Produção de $\mathrm{H}_{2} \mathrm{O}_{2}$ por macrófagos alveolares não estimulados e estimulados com PMA de animais KO e WT. (C) Leveduras viáveis recuperadas de macrófagos alveolares aderentes estimulados ou não com IFN- $\gamma(10.000 \mathrm{pg} / \mathrm{mL})$ e cultivados in vitro por 48 horas. (E) Leveduras viáveis recuperadas de macrófagos desafiados com $P$. brasiliensis. Macrófagos alveolares aderentes obtidos após 2 semanas de infecção foram estimulados ou não com IFN- $\gamma$ (10.000 pg/mL), desafiados com o P. brasiliensis (proporção 1:50 Pb: macrófagos) e posteriormente cultivados por 48 horas. (D e F) Níveis de NO nos sobrenadantes de macrófagos alveolares desafiados (F) ou não (D) com leveduras de P. brasiliensis. As barras representam as médias \pm EP do número de UFC (6-8 animais por grupo) * $(\mathrm{P}<0.05)$, $* *(\mathrm{P}<0.01) * * *(\mathrm{P}<0.001)$ comparado com os grupos $\mathrm{WT}$. 


\subsection{ESTUDO DA ATIVIDADE FUNGICIDA IN VITRO E DA PRODUÇÃO DE NO POR MACRÓFAgOS ALVEOLARES DE CAMUNDONGOS INOS KO E SEU GRUPO CONTROLE APÓS 10 SEMANAS DE INFECÇÃO}

Após o estudo da atividade fungicida de macrófagos alveolares de animais KO e WT na segunda semana de infecção, e com o mesmo protocolo acima descrito, propusemos então avaliar a atividade fungicida dessas células na décima semana de infecção onde verificamos expressiva carga fúngica pulmonar nos animais NO-deficientes, em relação ao grupo WT (Figura 1D).

Assim, corroborando com os dados apresentados na figura 1D, a figura 3A mostra que um maior número de células leveduriformes foi recuperado dos macrófagos, não ativados ou com adição de IFN- $\gamma$, de animais iNOS KO em relação ao grupo controle WT, (WT:191,3 \pm 21,11, KO: 354,2 $\pm 22,9$ fungos recuperados; WT+IFN- $\gamma: 45,3 \pm 1,15, \mathrm{KO}+\mathrm{IFN} \gamma: 302 \pm 31,3$ fungos recuperados).

Quando os macrófagos foram ativados com IFN- $\gamma$, mais uma vez, como visto na figura 2C, somente os macrófagos de animais WT, e não os de iNOS KO, apresentaram expressiva diminuição do número de fungos recuperados (WT: 191,3 $\pm 21,11$, WT+IFN- $\gamma$ : 45,2 $\pm 1,16$ fungos recuperados) em relação aos macrófagos não ativados. Além disso, concomitante com esse resultado, os macrófagos de animais WT ativados com IFN- $\gamma$ apresentaram maior produção de NO $(89,54 \pm$ 9,57 $\mu \mathrm{M})$ em relação aos macrófagos não ativados $(3,12 \pm 1,96 \mu \mathrm{M})$ (Figuras 3A e 3B, respectivamente).

Nas culturas de macrófagos, tratadas ou não com IFN- $\gamma$, que receberam um desafio adicional de leveduras de P. brasiliensis, após 48 horas de cultivo, foi caracterizado o número de UFC para ambos os grupos de animais estudados. Deste modo, uma elevada carga fúngica foi recuperada dos macrófagos de ambas as linhagens (Figura 3C). Quando o IFN- $\gamma$ foi adicionado às culturas, observamos mais uma vez uma maior atividade microbicida de macrófagos dos animais WT, (WT: 478,34 \pm 101,83, WT+ IFN- $\gamma$ : 37,2 \pm 5,71 fungos recuperados), em relação aos macrófagos não ativados, o mesmo não tendo ocorrido com os animais NOS $^{-/}$. Observou-se também maior produção de NO por macrófagos de animais WT quando ativados pela citocina (WT: $2,83 \pm 0,55$, WT+IFN- $\gamma$ : 98,44 $\pm 10,38 \mu \mathrm{M}$ ) (Figuras 3C e $3 \mathrm{D}$, respectivamente). 
Mais uma vez, nossos resultados mostram que somente macrófagos de animais normais para iNOS podem ser ativados por IFN- $\gamma$ o qual é responsável pela maior atividade fungicida desses macrófagos que produzem níveis elevados de óxido nítrico.
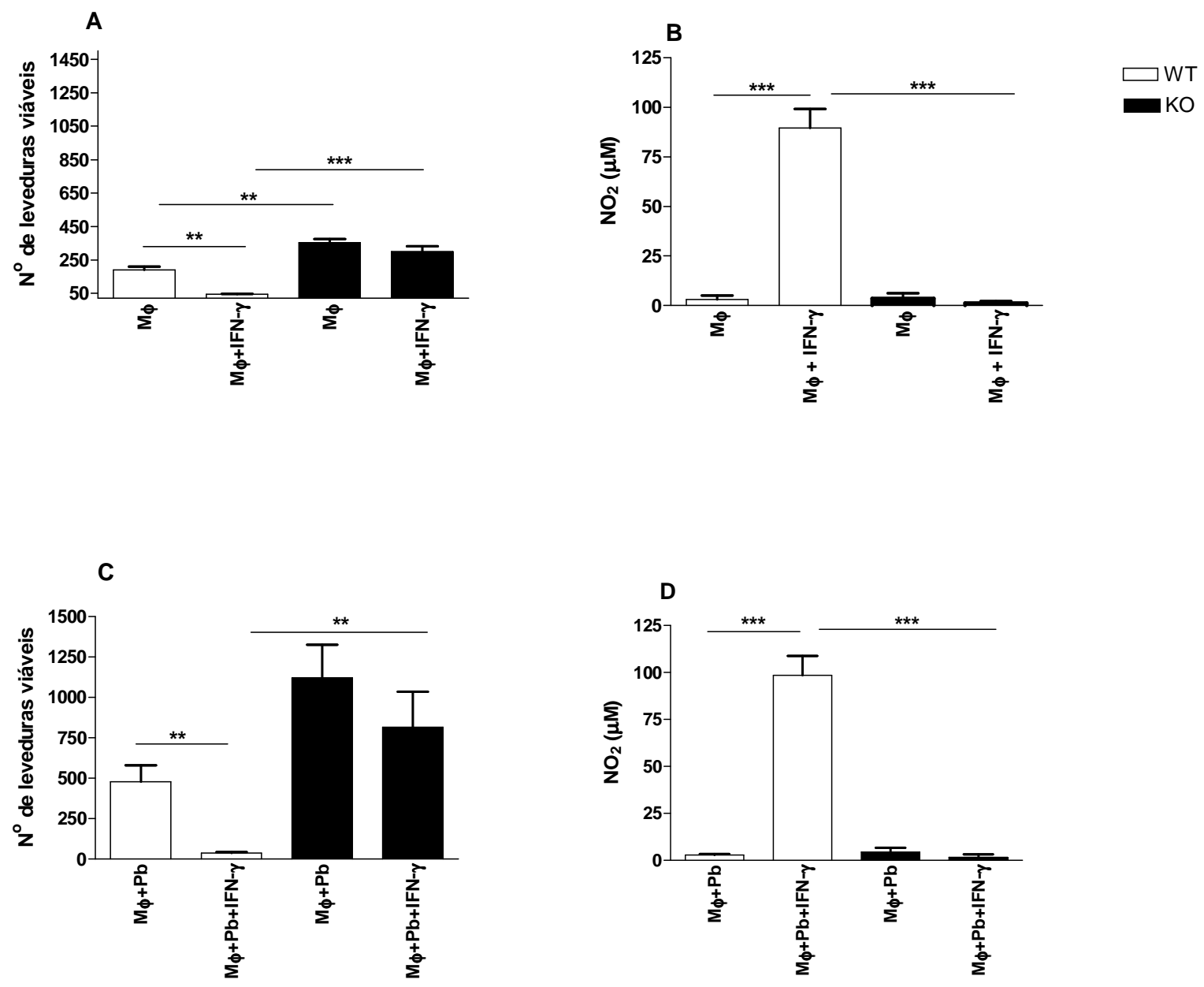

Figura 3. Na décima semana de infecção, os animais iNOS KO apresentam um maior número de fungos recuperados dos macrófagos alveolares os quais apresentam uma menor atividade fungicida. (A) Leveduras viáveis recuperadas de macrófagos alveolares aderentes estimulados ou não com IFN- $\gamma(10.000 \mathrm{pg} / \mathrm{mL})$ e cultivados in vitro por 48 horas. (C) Leveduras viáveis recuperadas de macrófagos desafiados com $P$. brasiliensis. Macrófagos alveolares aderentes obtidos após 10 semanas de infecção foram estimulados ou não com IFN- $\gamma(10.000 \mathrm{pg} / \mathrm{mL}$ ), desafiados com o P. brasiliensis (proporção 1:50 Pb: macrófagos) e posteriormente cultivados por 48 horas. (B e D) Níveis de NO nos sobrenadantes de macrófagos alveolares desafiados (D) ou não (B) com leveduras de $P$. brasiliensis. As barras representam as médias \pm EP do número de UFC (6-8 animais por grupo) $*(\mathrm{P}<0.05)$, $* *(\mathrm{P}<0.01) \mathrm{e}^{* * *}(\mathrm{P}<0.001)$ comparado com os grupos $\mathrm{WT}$. 


\subsection{ANÁLISE FENOTÍPICA DE LINFÓCITOS INFILTRANTES DE PULMÃO DE ANIMAIS INOS KO E SEU GRUPO CONTROLE WT NAS SEGUNDA E DÉCIMA SEMANAS DE INFECÇÃO}

Analisamos o perfil do infiltrado de linfócitos T, durante as segunda e décima semanas de infecção pulmonar pelo $P$. brasiliensis, nos pulmões de animais iNOS KO e seu grupo WT isolados pela técnica de Percol e quantificados por citometria de fluxo. Foram caracterizadas as sub-populações $\mathrm{T} \mathrm{CD}^{+}, \mathrm{T} \mathrm{CD}^{+}$e os marcadores de ativação $\mathrm{CD} 9^{+}$que caracteriza ativação celular precoce e $\mathrm{CD}_{2} 5^{+}$que é a cadeia $\alpha$ do receptor de IL-2, característico de células ativadas.

Os resultados são apresentados em valor absoluto de células conforme descrito em material e métodos (item 9). As barras representam as médias \pm EP dos grupos ensaiados. Estes resultados referem-se a 2 experimentos com resultados semelhantes. A análise no FACS Calibur tomou por base o gate para linfócitos considerando tamanho (FSC) e granulosidade (SSC) celular.

A figura 4 mostra que camundongos iNOS KO nas segunda e décimas semanas de infecção apresentam número aumentado de linfócitos $\mathrm{T} \mathrm{CD}^{+}$e $\mathrm{T} \mathrm{CD} 4^{+} \mathrm{CD} 69^{+}$ativados, em comparação aos animais WT iNOS normais. Somente os animais KO apresentaram maior número de células ativadas $\mathrm{CD} 9^{+}$nos pulmões durante a segunda semana de infecção. Observamos também grande número de linfócitos expressando o marcador de ativação CD25 nos pulmões dos animais deficientes em comparação ao grupo WT na fase aguda da infecção. Ainda houve aumento do número de linfócitos duplo positivos $\mathrm{T} \mathrm{CD} 4{ }^{+} \mathrm{CD} 25^{+}$nos pulmões de animais deficientes de óxido nítrico em ambos os períodos estudados.

Analisamos também, durante estes experimentos, o perfil de linfócitos T CD8 ${ }^{+}$ infiltrantes de pulmão para ambos os grupos de animais nos 2 períodos de infecção. Somente no período de 2 semanas, de modo semelhante ao obtido com linfócitos TCD4 ${ }^{+}$, o número das células $\mathrm{T} \mathrm{CD}^{+}$, de células que expressam marcador de ativação $\mathrm{CD}^{+} 9^{+}$e linfócitos duplo positivos $\mathrm{T} \mathrm{CD}^{+} \mathrm{CD}^{+} 9^{+}$ativados, foi maior nos animais $\mathrm{KO}$ do que nos animais WT. No tempo mais tardio essa população linfocitária foi semelhante para ambas as linhagens de animais analisadas (Figura 4).

O aumento de células T ativadas nos animais iNOS KO é concomitante com a menor carga fúngica pulmonar nesses animais no período de 2 semanas após infecção. Por outro 
lado, na décima semana, a maior carga fúngica pulmonar observada nos animais deficientes foi concomitante com um maior número de linfócitos $\mathrm{T} \mathrm{CD}^{+}$, porém não de linfócitos $\mathrm{T}$ $\mathrm{CD}^{+}$. 
2 Semanas
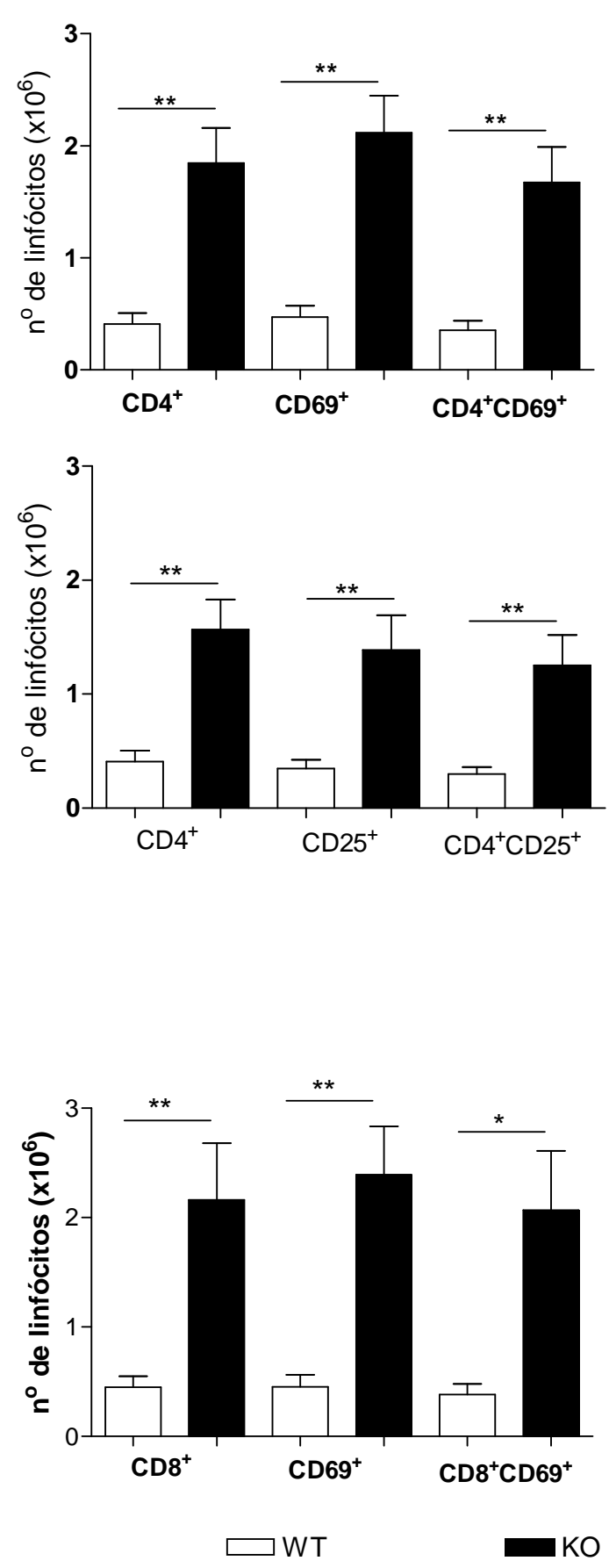

10 Semanas
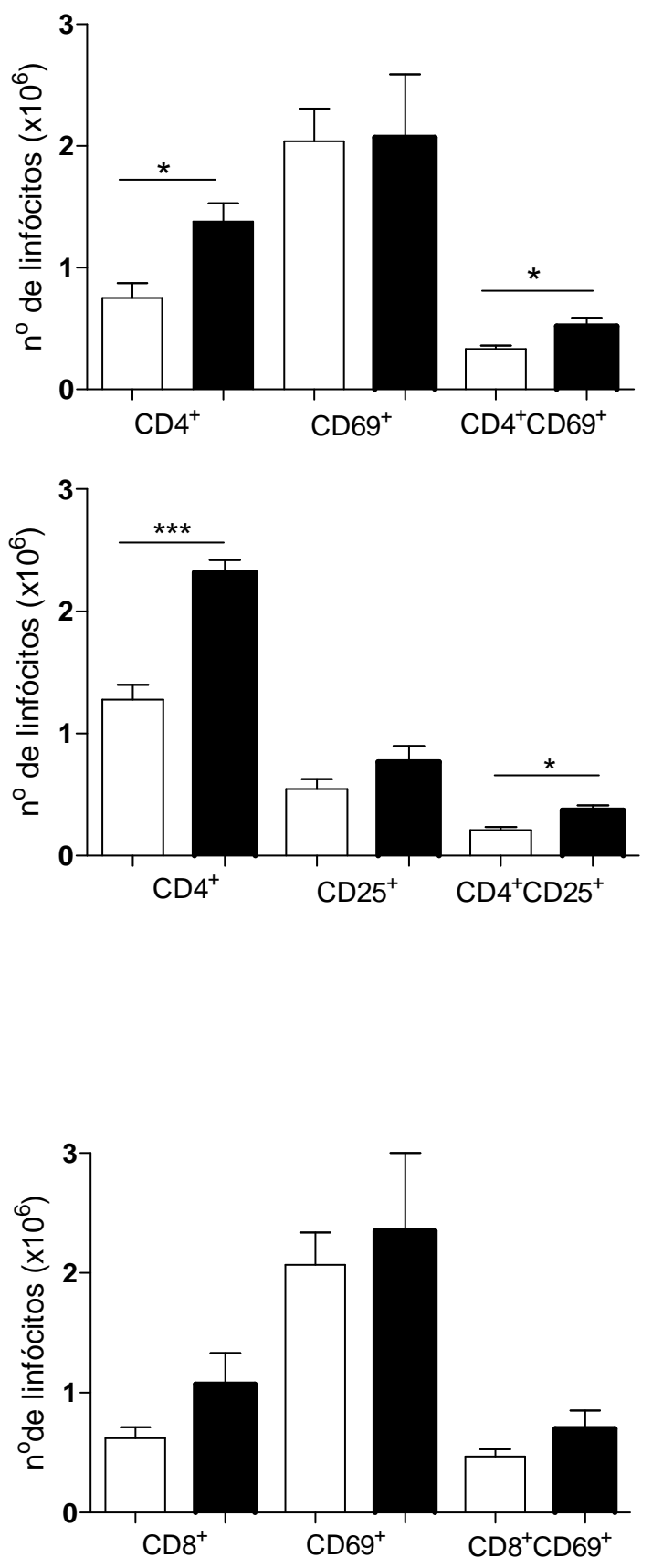

Figura 4. Quantificação de linfócitos $\mathrm{T}$ CD $4^{+}$totais e ativados $\left(\mathrm{CD} 4^{+} \mathrm{CD} 69^{+}\right.$e $\left.\mathrm{CD} 4^{+} \mathrm{CD} 25^{+}\right)$e de linfócitos $\mathrm{T} \mathrm{CD}^{+}$totais e ativados $\left(\mathrm{CD} 8^{+} \mathrm{CD} 69^{+}\right)$presentes nos pulmões de camundongos KO (n=5) e seu grupo WT (n=5) nas segunda e décima semanas de infecção com 1 x $10^{6}$ leveduras viáveis de $P$. brasiliensis por via i.t. A expressão de $\mathrm{CD} 4^{+}, \mathrm{CD}^{+}, \mathrm{CD}^{2} 9^{+} \mathrm{e}$ $\mathrm{CD} 25^{+}$foi determinada por citometria de fluxo. $\mathrm{O}$ valor absoluto de cada sub-população é apresentado como média \pm EP. $* P<0,05, * * P<0,01$, ***P<0,001 estatisticamente significante. 


\subsection{CARACTERIZAÇÃO DA PRESENÇA DE CÉLULAS T REGULADORAS DO FENÓTIPO T $\mathrm{CD4}^{+} \mathrm{CD}^{+} 5^{+} \mathrm{FOXP3}^{+}$NO PULMÃO DE ANIMAIS INOS KO E SEU GRUPO CONTROLE WT NAS SEGUNDA E DÉCIMA SEMANAS DE INFECÇÃO}

Analisamos a presença de células $\mathrm{T}$ reguladoras $\mathrm{CD} 4^{+} \mathrm{CD} 25^{+} \mathrm{FoxP} 3^{+}$no infiltrado pulmonar de camundongos iNOS KO e seu grupo WT, pela técnica de citometria de fluxo. A porcentagem de células $\mathrm{TCD}^{+} \mathrm{CD} 25^{+} \mathrm{FoxP} 3^{+}$foi obtida pela quantificação de células triplamente positivas em gate de células $\mathrm{T} \mathrm{CD} 4^{+} \mathrm{CD} 25^{+}$. As populações de linfócitos totais, linfócitos $\mathrm{T} \mathrm{CD}^{+}$, $\mathrm{TCD} 4^{+} \mathrm{CD} 25^{+}$e células $\mathrm{T} \mathrm{CD} 4^{+} \mathrm{CD} 25^{+} \mathrm{FoxP} 3^{+}$com relação ao tamanho e granulosidade dessas células, foram determinadas em porcentagem utilizando "gates" individuais.

A figura 5 mostra que na segunda semana de infecção, o número de células $\mathrm{T}$ reguladoras em animais deficientes de óxido nítrico foi semelhante ao do grupo WT. Vale lembrar que neste período de infecção houve aumento de linfócitos T CD4 ${ }^{+}$e linfócitos ativados $\mathrm{T} \mathrm{CD} 4^{+} \mathrm{CD} 25^{+}$nos pulmões de animais $\mathrm{KO}$ (Figura 4) podendo essas células ter um papel importante com relação à menor carga fúngica pulmonar observada neste momento da doença. Por outro lado, na fase crônica do nosso modelo, observamos aumento de células T reguladoras nos pulmões dos animais KO comparado ao grupo WT (WT: 2,6 \pm 0,075\%, KO: 4,6 $\pm 0,12 \%$ ) (Figura 5). Este aumento de células reguladoras durante o período de 10 semanas pós-infecção pode ter uma correlação com a maior carga fúngica pulmonar, além de menor ativação do infiltrado linfocitário observado nos pulmões dos animais deficientes de NO. 


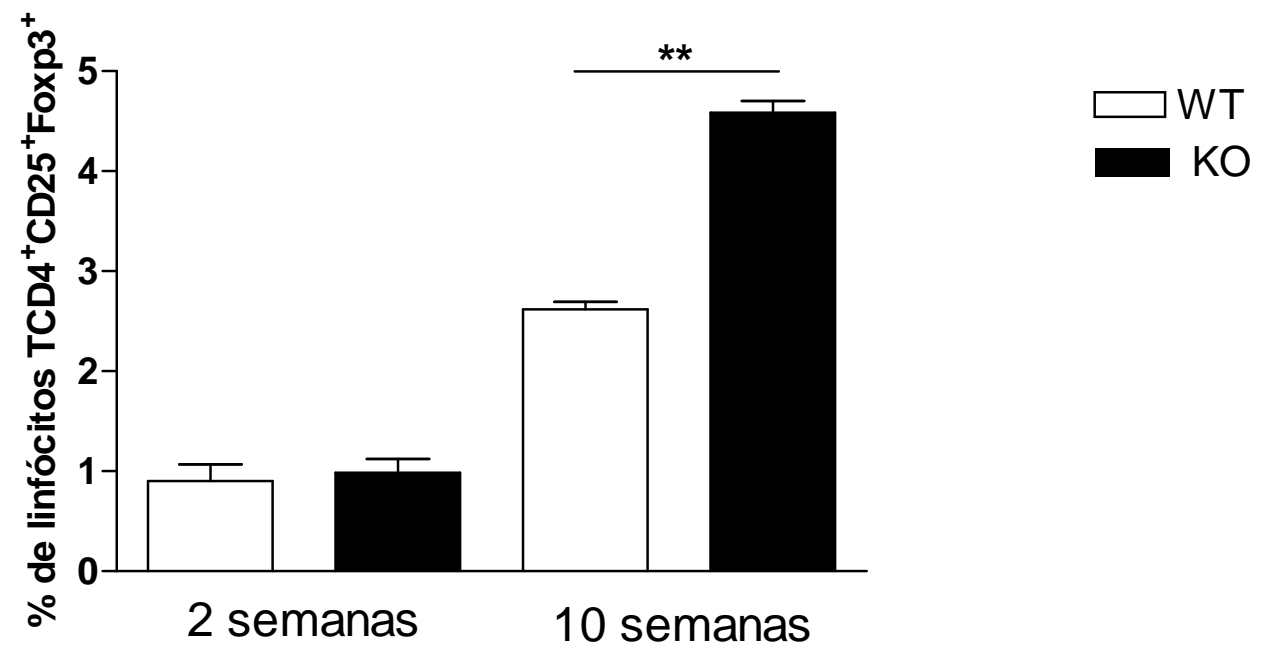

Figura 5. Frequência de linfócitos $\mathrm{T} \mathrm{CD} 4^{+} \mathrm{CD} 25^{+} \mathrm{FoxP} 3^{+}$presentes nos pulmões de camundongos $\mathrm{KO}$ $(\mathrm{n}=6)$ e seu grupo WT $(\mathrm{n}=6)$ nas segunda e décima semanas de infecção com 1 x $10^{6}$ leveduras viáveis de $P$. brasiliensis por via i.t.. A expressão de linfócitos $\mathrm{CD}^{+} \mathrm{CD} 25^{+}$ $\mathrm{FoxP}^{+}$foi determinada por citometria de fluxo. O valor em porcentagem (\%) de cada população é apresentado como média $\pm \mathrm{EP}$. $* * P<0,01$ estatisticamente significante. 


\subsection{ANÁLISE FENOTÍPICA DE MACRÓFAGOS ALVEOLARES DE ANIMAIS INOS KO E SEU GRUPO CONTROLE WT NAS SEGUNDA E DÉCIMA SEMANAS DE INFECÇÃO}

O estudo de receptores de macrófagos, Ia $^{\mathrm{b}}$ (MHC classe II) e CD11b, como de moléculas coestimuladoras CD80 (B7.1), CD86 (B7.2) e CD40, foi realizado para caracterizar a presença e ativação de macrófagos pulmonares de camundongos $\mathrm{KO}$ e seu grupo controle WT após 2 e 10 semanas de infecção. A análise destes experimentos foi feita no FACS Calibur considerando o "gate" de tamanho (FSC) e granulosidade (SSC) para macrófagos.

Foi feita a análise da expressão de $\mathrm{CD}_{11 \mathrm{~b}^{+}}$e CD86 ${ }^{+}$em macrófagos pulmonares em ambos os grupos ensaiados, mas somente na segunda semana foi vista um maior número de macrófagos expressando $\mathrm{CD} 11 \mathrm{~b}^{+}, \mathrm{CD}_{6} 6^{+}$e ambos os marcadores $\mathrm{CD}_{11 \mathrm{~b}^{+} \text {e CD86 }}{ }^{+}$nos animais KO em relação ao grupo WT (Figura 6).

Obtivemos maior número de células expressando o marcador $\mathrm{CD}^{+} 0^{+} \mathrm{em}$ animais iNOS KO nas segunda e décima semanas de infecção, porém com maior número de células no infiltrado pulmonar nos animais KO na fase crônica do que nos animais deficientes na fase aguda. As células expressando $\mathrm{CD}^{+} 6^{+}$e ambos os marcadores $\mathrm{CD}^{+} 0^{+}$e $\mathrm{CD}^{+} 6^{+}$foram observadas em maior número nos pulmões de animais KO quando comparado ao grupo WT somente na fase aguda.

A figura 6 mostra ainda a expressão dos receptores $\mathrm{Ia}^{\mathrm{b}}$ e de $\mathrm{CD} 40^{+}$em macrófagos pulmonares de animais deficientes de oxido nítrico, bem como seu grupo controle WT. Na fase aguda, foi observado significante aumento de células expressando de $\mathrm{Ia}^{\mathrm{b}} \mathrm{em}$ animais KO. Já o número de macrófagos expressando $\mathrm{CD}_{4} 0^{+}$foi maior em animais $\mathrm{KO}$ do que nos do grupo WT nos 2 períodos estudados; mais uma vez observou-se um maior infiltrado celular nos pulmões dos animais KO na décima do que na segunda semana pós infecção. As células duplo positivas $\mathrm{Ia}^{\mathrm{b}+} \mathrm{CD} 40^{+}$estiveram aumentadas nos animais $\mathrm{KO}$ com relação ao grupo WT só na fase aguda do nosso modelo.

Para melhor caracterizarmos as populações de macrófagos e células dentrícas, foi realizado um "gate" para macrófagos em $\mathrm{CD} 11 \mathrm{~b}^{\text {high }} \mathrm{CD} 80^{\text {high }}$, e um "gate" para células dendríticas em $\mathrm{CD} 11 \mathrm{c}^{\text {high }} \mathrm{CD} 86^{\text {high }}$ na segunda semana de infecção. A figura 6.1 mostra que somente os macrófagos apresentaram-se em número aumentado no infiltrado pulmonar de 
animais NO deficientes com relação ao grupo controle. O número de células dendríticas foi equivalente em ambas as linhagens de camundongos.

Na segunda semana de infecção, como visto para os linfócitos infiltrantes de pulmão, observamos aumento significativo destes marcadores de superfície em macrófagos de animais deficientes de óxido nítrico. Já na décima semana, embora a maioria dos macrófagos de animais KO encontrava-se pouco ativada, com relação aos macrófagos da segunda semana, pudemos observar um maior infiltrado celular nos pulmões destes animais durante este período da doença. 

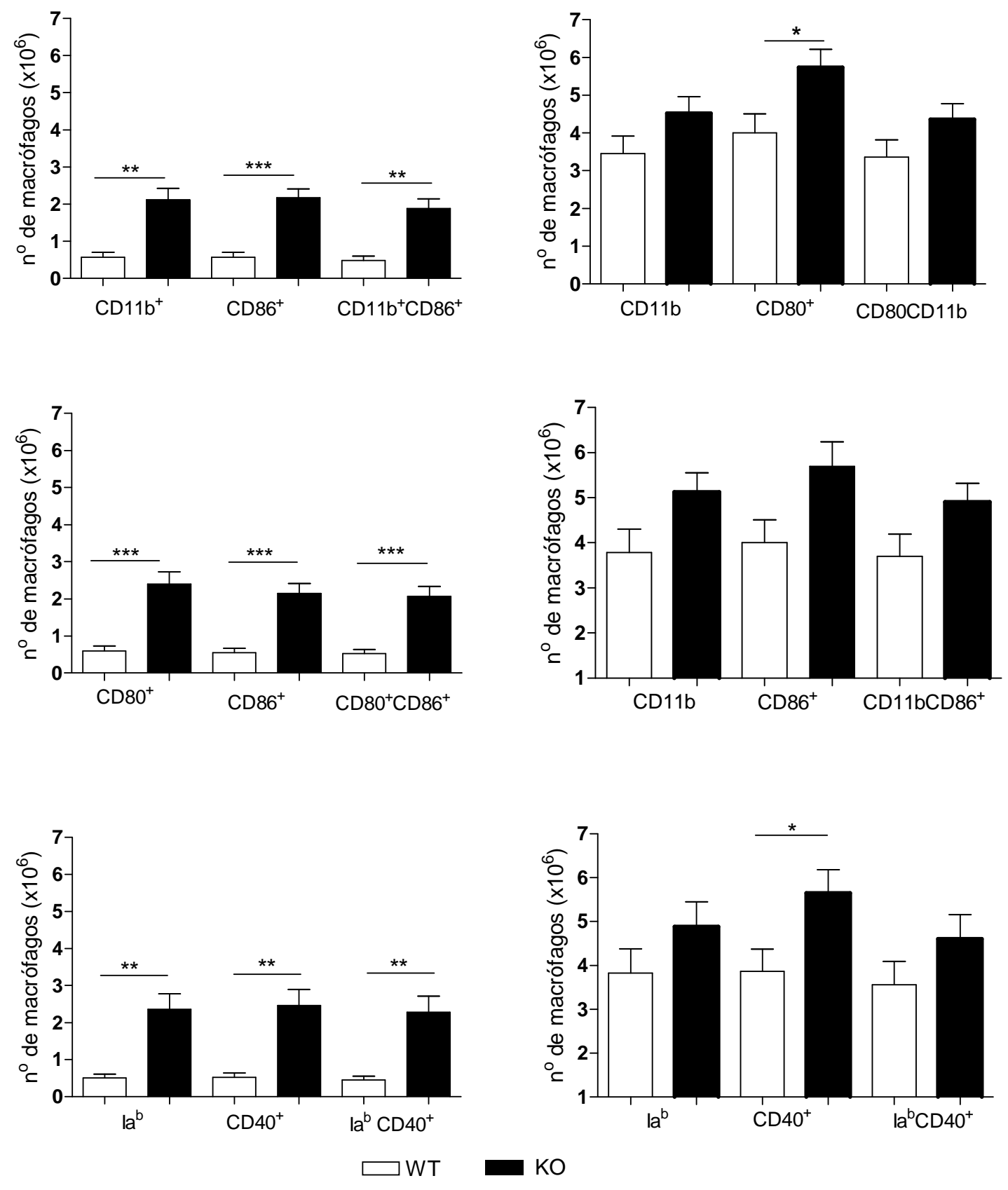

Figura 6. Quantificação de macrófagos infiltrantes de pulmão expressando os marcadores CD11b, $\mathrm{CD}^{2} 6^{+}, \mathrm{CD} 80^{+}, \mathrm{Ia}^{\mathrm{b}}$ e CD $40^{+}$de camundongos $\mathrm{KO}(\mathrm{n}=5)$ e seu grupo controle WT $(\mathrm{n}=5)$ nas segunda e décima semanas de infecção com $1 \times 10^{6}$ leveduras viáveis de $P$. brasiliensis por via i.t. A expressão de $\mathrm{CD}_{11 b^{+},}, \mathrm{CD} 6^{+}, \mathrm{CD} 80^{+}, \mathrm{Ia}^{\mathrm{b}}$ e $\mathrm{CD} 40^{+}$foi determinada por citometria de fluxo. O valor absoluto de cada sub-população é apresentado como média \pm EP.* $P<0,05, * * P<0,01, * * * P<0,001$ estatisticamente significante. 


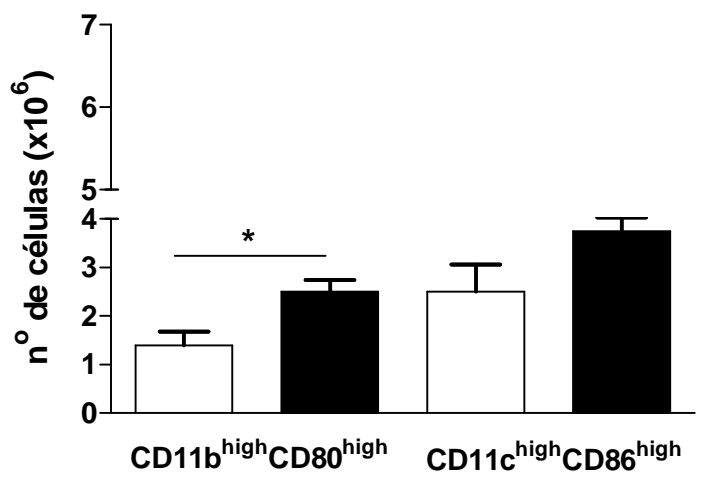

Figura 6.1. Quantificação de macrófagos $\mathrm{CD} 11 \mathrm{~b}^{\text {high }} \mathrm{CD} 80^{\text {high }}$ e de células dendríticas $\mathrm{CD} 11 \mathrm{c}^{\text {high }} \mathrm{CD} 86^{\text {high }}$ infiltrantes de pulmão de camundongos $\mathrm{KO}(\mathrm{n}=5)$ e seu grupo controle WT $(\mathrm{n}=5)$ na segunda semana de infecção com 1 x $10^{6}$ leveduras viáveis de $P$. brasiliensis por via i.t.. A expressão de $\mathrm{CD} 11 \mathrm{~b}^{\text {high }} \mathrm{CD} 80^{\text {high }}$ e de $\mathrm{CD} 11 \mathrm{c}^{\text {high }} \mathrm{CD} 86^{\text {high }}$ foi determinada por citometria de fluxo. $\mathrm{O}$ valor absoluto de cada sub-população é apresentado como média $\pm \mathrm{EP}$. $* P<0,05$, estatisticamente significante. 


\subsection{EFEITO DA DEPLEÇÃO IN VIVO DA CITOCINA TNF- $\alpha$ NA GRAVIDADE DA DOENÇA}

$\mathrm{Na}$ fase aguda do nosso modelo, 2 semanas de infecção, observamos que os animais deficientes de óxido nítrico apresentavam baixa carga fúngica pulmonar acompanhada de altos níveis de TNF- $\alpha$ (figuras 1 A, B) comparado ao grupo WT. Deste modo, propusemos o estudo da depleção desta citocina próinflamatória no nosso modelo de infecção, já que a mesma poderia exercer um papel importante no controle na carga fúngica e desenvolvimento da imunidade dos animais iNOS KO.

O resultado a seguir refere-se ao experimento realizado com a inoculação de $1 \times 10^{6}$ leveduras viáveis de $P$. brasiliensis por via intratraqueal (i.t.) nos animais C57BL/6 iNOS KO (KO) e C57BL/6 (WT). Esses animais foram tratados ou não com anticorpo monoclonal antiTNF- $\alpha$ na concentração de $250 \mu \mathrm{g} / 0,5 \mathrm{~mL}$ via i.p. nos dias 0 (4 horas antes da infecção), 6 e 12 de infecção. Grupos de camundongos KO e WT também foram tratados com IgG normal de rato, $250 \mu \mathrm{g} / 0,5 \mathrm{~mL}$ via i.p., nos mesmos dias utilizados para o anticorpo monoclonal.

A figura 7A mostra que o tratamento com o anticorpo anti-TNF- $\alpha$ nos animais iNOS $\mathrm{KO}\left(3,77 \pm 0,34 \log _{10}\right)$ levou a carga fúngica pulmonar equivalente àquela do grupo WT IgG $\left(4,52 \pm 0,31 \log _{10}\right)$ na segunda semana de infecção. Assim, observamos que o bloqueio da citocina próinflamatória TNF- $\alpha$ aumentou a carga fúngica nos animais deficientes de óxido nítrico, demonstrando que a neutralização deste mediador abole a diferença da carga fúngica entre animais KO e seu grupo WT não depletado. Foi observada disseminação para fígado e baço, mas sem diferença estatisticamente significante (Figura 7A). Como esperado e demonstrado na figura $1 \mathrm{~A}$, os animais $\mathrm{KO} \operatorname{IgG}\left(3,25 \pm 0,32 \log _{10}\right)$ têm carga fúngica pulmonar inferior a dos animais WT IgG $\left(4,51 \pm 0,31 \log _{10}\right)$. Após 2 semanas de infecção, a ausência de óxido nítrico nos animais KO depletados de TNF- $\alpha\left(3,77 \pm 0,34 \log _{10}\right)$, induz carga fúngica pulmonar inferior àquela observada nos animais WT tratados com anti-TNF- $\alpha$ $\left(4,85 \pm 0,27 \log _{10}\right)$.

Como nossos resultados de fase crônica da doença foram realizados na décima semana de infecção, planejamos inicialmente caracterizar a gravidade da doença dos animais KO e WT tratados com anti-TNF- $\alpha$ e IgG normal neste período pós infecção. Porém, a partir do 
primeiro mês de infecção os camundongos KO anti-TNF- $\alpha(n=6)$ começaram a morrer não sendo possível realizar o experimento na décima semana.

Deste modo, apresentamos na figura 7B a recuperação de fungos viáveis na oitava semana de infecção dos animais KO e WT tratados com anti-TNF- $\alpha$ e seu grupo IgG normal.

A figura 7B mostra que, como esperado na oitava semana de infecção, os animais KO $\operatorname{IgG}\left(5,9 \pm 0,25 \log _{10}\right)$ apresentaram número maior de fungos nos pulmões que o grupo WT $\operatorname{IgG}\left(4,3 \pm 0,54 \log _{10}\right)$. A depleção do TNF- $\alpha$ levou ao aumento de fungos nos pulmões de ambos os grupos (KO: 6,1 \pm 0,41 $\log _{10}$, WT: 5,14 $\pm 0,19 \log _{10}$ ), não resultando, porém, em diferença estatisticamente significante entre os animais tratados e não tratados. Os animais $\mathrm{KO}$ anti-TNF- $\alpha$ tiveram carga fúngica semelhante a dos animais KO IgG.

Dos seis animais KO infectados e depletados de TNF- $\alpha$, somente um sobreviveu na décima semana pós-infecção (Figura 7C). Um animal KO-anti-TNF- $\alpha$ sobrevivente foi sacrificado na décima semana de infecção e analisado quanto à carga fúngica. Os pulmões, fígado e baço apresentavam-se com lesões endurecidas e esbranquiçadas sob inspeção macroscópica. Deste animal foi feita a análise histopatológica das lesões de pulmão, fígado e baço corados com hematoxilina e eosina. No lóbulo direito dos pulmões observou-se presença de lesão frouxa, com infiltrado linfocitário disperso, com necrose por todo o parênquima pulmonar, além de grande número de fungos. Houve formação de infiltrado celular com presença de neutrófilos sem a organização das lesões em granulomas. A lesão hepática apresentou-se com necrose, deposição de matriz extracelular na porção mais externa, além da presença de fungos e neutrófilos. No baço houve também necrose, deposição de matriz extracelular, além de fungos e neutrófilos (dados não mostrados).

Foram sacrificados dois animais WT-anti-TNF- $\alpha$ sobreviventes e feita a análise histológica de pulmão, fígado e baço. Observou-se presença de grande número de fungos nos pulmões com presença de células gigantes e neutrófilos. $\mathrm{O}$ baço apresentou lesão com grande quantidade de fungos e presença de células gigantes. O fígado, além da grande quantidade de fungos, apresentou aspecto normal do parênquima (dados não mostrados).

Estes dados demonstram que a depleção de TNF- $\alpha$ parece exercer um efeito exacerbador da doença mais marcante em animais iNOS KO do que nos controles iNOS normais. 
A

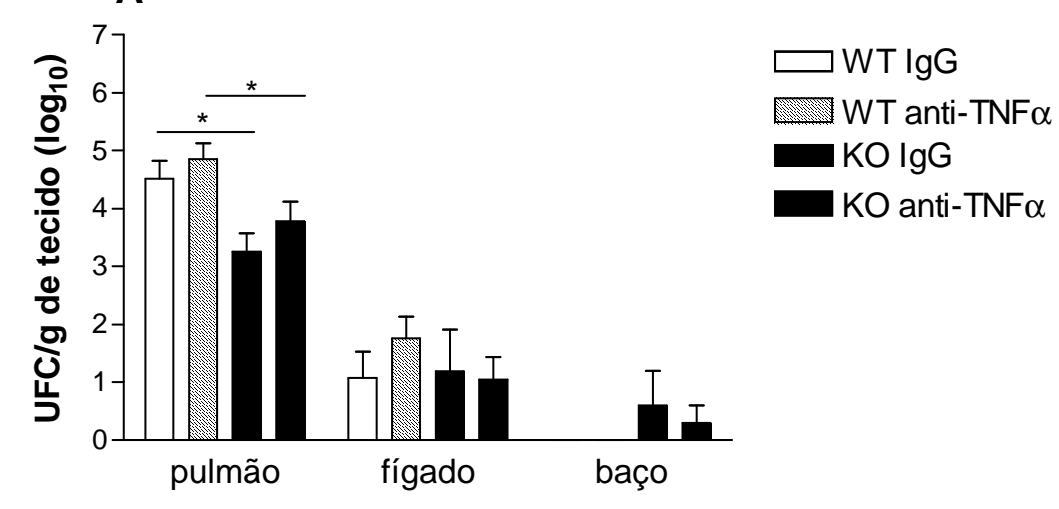

8 Semanas pós infecção
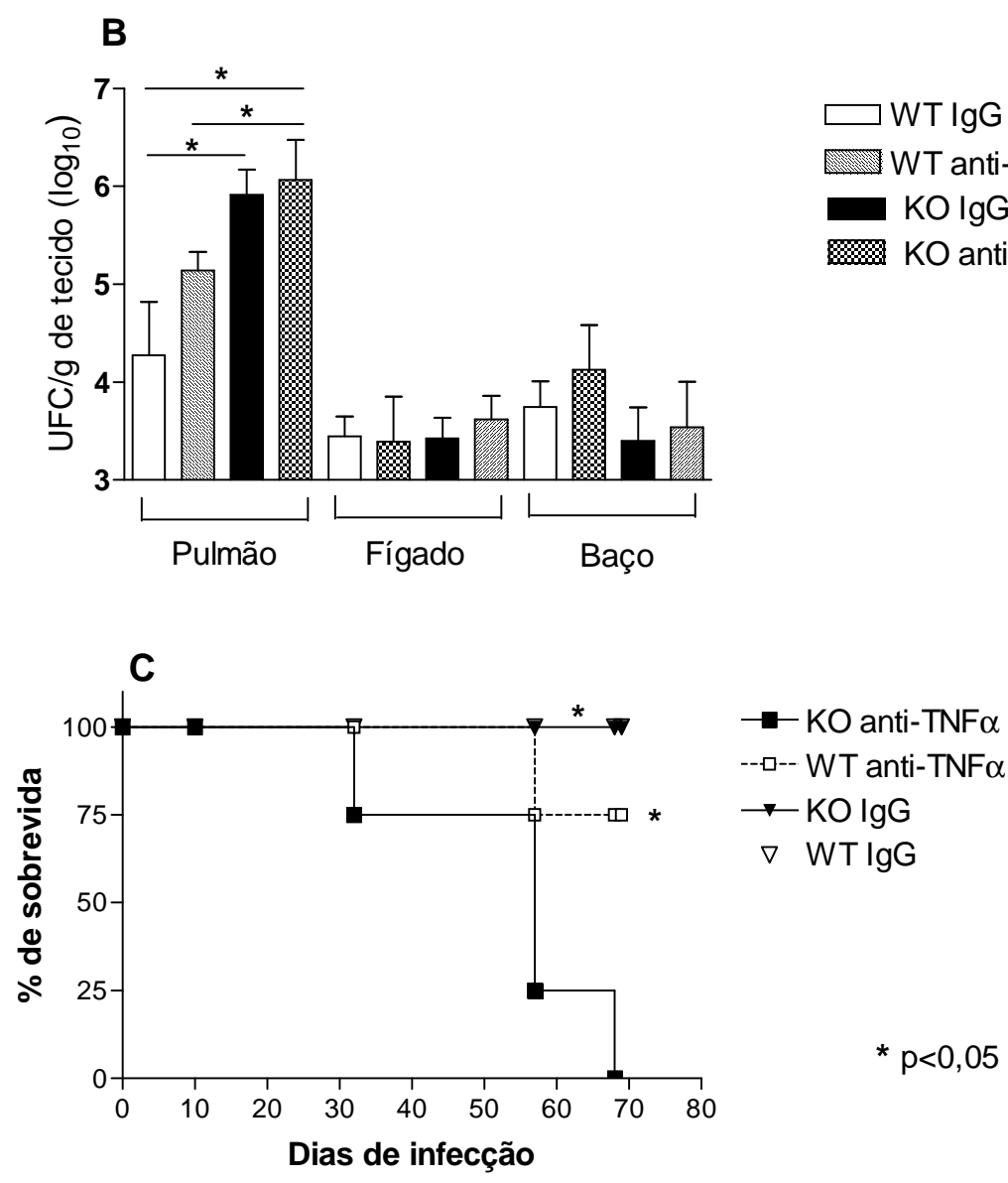

Figura 7. (A e B) Avaliação da gravidade da doença por contagem do número de Unidades Formadoras de Colônias UFC/g de tecido $\left(\mathrm{em} \log _{10}\right)$ no pulmão, fígado e baço em camundongos $\mathrm{KO}(\mathrm{n}=8)$ e WT $(\mathrm{n}=7)$ após 2 e 8 semanas de infecção com 1 x $10^{6}$ leveduras de $P$. brasiliensis inoculadas pela via i.t. e tratados com $250 \mu \mathrm{g} / 0,5 \mathrm{~mL}$ de antiTNF- $\alpha$, por via i.p. nos dias 0,6 e 12 de infecção. Animais KO $(n=8)$ e WT $(n=7)$ foram tratados com IgG normal de rato na mesma concentração e dias como controle adicional. As barras representam as médias $\pm \mathrm{EP}$ dos grupos ensaiados. $\mathrm{O}$ asterisco $(*)$ representa diferença significante $(* \mathrm{P}<0,05)$. (C) Efeito da depleção do TNF- $\alpha$ no tempo de sobrevida de camundongos iNOS KO $(n=6)$ e os grupos WT $(n=6)$ infectados com 1 x $10^{6}$ leveduras de $P$. brasiliensis inoculadas pela via i.t.. $\mathrm{O}$ asterisco $(*)$ representa diferença significante (* $\mathrm{P}<0,05 ; \mathrm{KO}$ anti-TNF- $\alpha$ x WT anti-TNF- $\alpha$; KO anti-TNF- $\alpha \times \mathrm{KO} \operatorname{IgG}$ ). Experimento repetido 2 vezes. 


\subsection{EFEITO DA DEPLEÇÃO IN VIVO DA CITOCINA TNF- $\alpha$ NA PRODUÇÃo DE CITOCINAS PULMONARES E HEPÁTICAS}

Após avaliarmos a gravidade da doença em animais KO e WT depletados de antiTNF- $\alpha$, decidimos verificar se esta depleção poderia alterar o perfil de citocinas pro e antiinflamatórias produzidas por estes animais na segunda semana de infecção. Para tanto, os sobrenadantes de pulmões e fígado obtidos durante os experimentos para a quantificação de UFC foram conservados a $-70{ }^{\circ} \mathrm{C}$ e utilizados para a pesquisa de citocinas.

A figura 8 mostra que a neutralização de TNF- $\alpha$ resulta em diminuição dos níveis de IFN- $\gamma$ pulmonar em animais KO em relação ao grupo WT também depletado (WT anti-TNF$\alpha: 4367,31 \pm 542,75, \mathrm{KO}$ anti-TNF- $\alpha$ : 2888,53 $\pm 136,68 \mathrm{pg} / \mathrm{mL}$ ). Ainda, essa depleção levou ao aumento dos níveis de TGF- $\beta$ pulmonar em animais KO com relação ao grupo KO não depletado (KO anti-TNF- $\alpha$ : 4697,39 \pm 162 , KO IgG: $3630,34 \pm 128,52$ pg/mL). Para ambas as linhagens, não observamos alterações dos níveis de TNF- $\alpha$, IL-12 e IL-10 entre animais tratados e não tratados com anti-TNF- $\alpha$. Pudemos observar ainda que neste momento da infecção, os animais KO controle, apresentaram níveis aumentados de TNF- $\alpha$ (WT IgG: 4875 $\pm 199,31$, KO IgG: $5655,19 \pm 138,63$ pg/mL) e diminuídos de TGF- $\beta$ (WT IgG: 4312,53 \pm 101,69, KO IgG: $3630,35 \pm 128,52 \mathrm{pg} / \mathrm{mL}$ ) nos pulmões com relação ao grupo WT controle (Figura 8). Assim, níveis elevados de TNF- $\alpha$ e diminuídos de TGF- $\beta$ pulmonares de animais KO controle corroboram com a menor carga fúngica pulmonar, aumento do infiltrado leucocitário e frequência equivalente de células $\mathrm{T}$ reguladoras nos pulmões desses animais em relação ao grupo WT (Figuras 1A, 4, 5 e 6).

Ainda na figura 8 podemos observar que a depleção de TNF- $\alpha$ acarretou em diminuição dos níveis de IFN- $\gamma$ hepático nos animais KO depletados com relação ao grupo KO controle (KO anti-TNF- $\alpha$ : 7795,99 $\pm 335,76$, KO IgG: 8786,28 $\pm 208,89$ pg/mL). Para as demais citocinas, TNF- $\alpha$, IL-12, IL-10 e TGF- $\beta$, a depleção de TNF- $\alpha$ não resultou em diferença estatisticamente significante em relação aos grupos não tratados. Observamos também que quando a doença é menos grave na fase aguda houve, nos animais KO controle, aumento dos níveis hepáticos de IFN- $\gamma$ (WT IgG: 7878,23 \pm 179,35, KO IgG: 8786,28 \pm 208,89 pg/mL) e de IL-12 (WT IgG: 2645,76 $\pm 68,34$, KO IgG:2901,19 $\pm 43,86$ pg/mL) com relação ao grupo WT controle (Figura 8). 


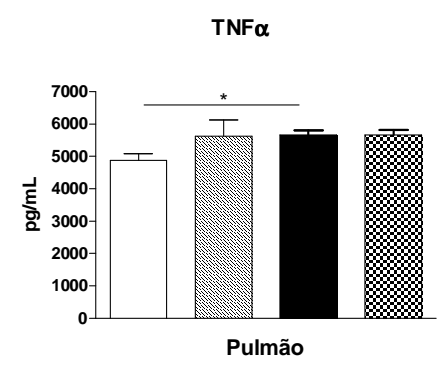

IFN $\gamma$

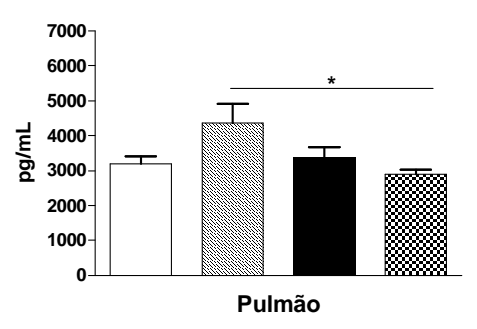

IL12

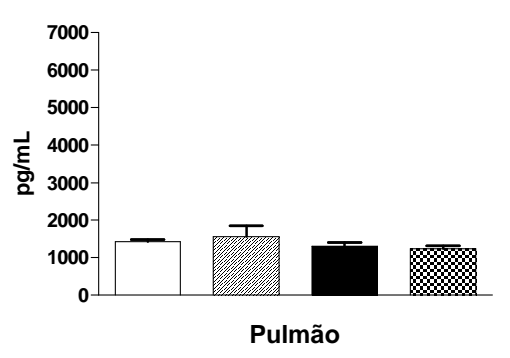

IL10
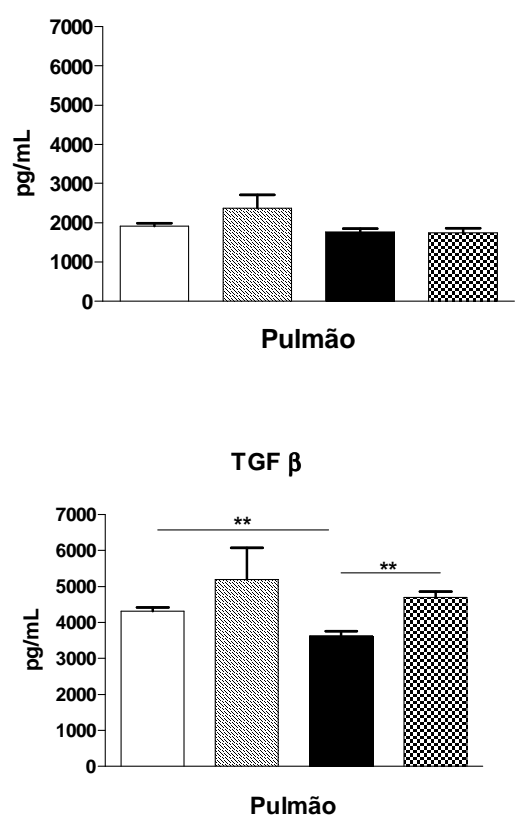

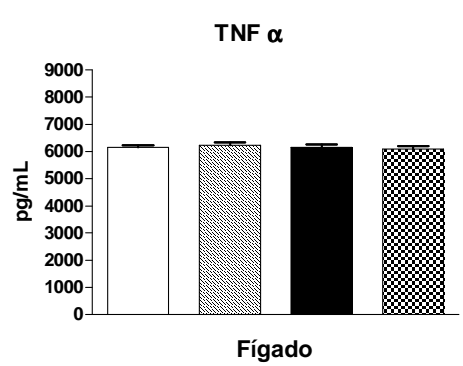

IFN $\gamma$
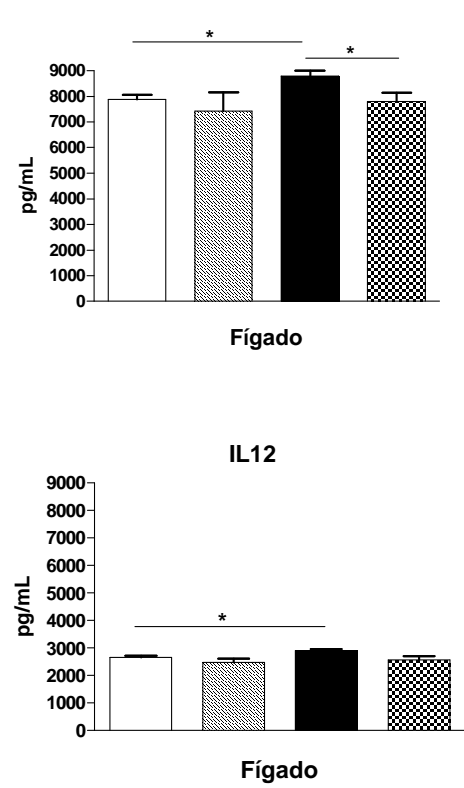

IL 10

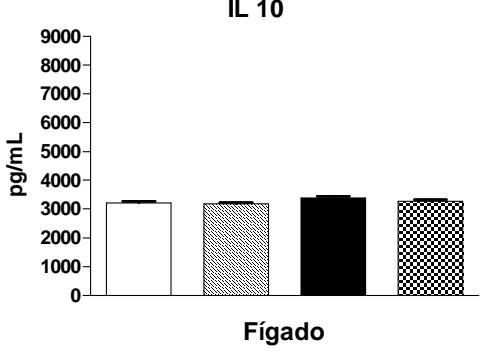

TGF $\beta$

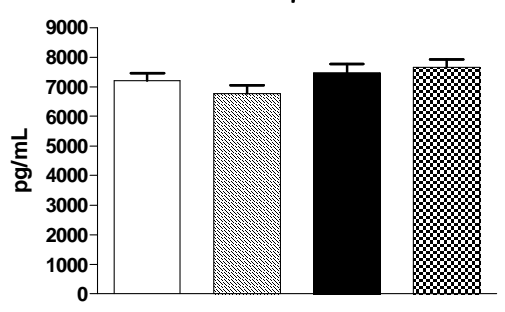

Fígado

Figura 8. Quantificação de citocinas presentes no sobrenadante de pulmão e fígado de animais WT $(\mathrm{n}=7)$ e KO (n=8) após 2 semanas de infecção com 1 × $10^{6}$ leveduras de P. brasiliensis inoculadas pela via i.t. e tratados com $250 \mu \mathrm{g} / 0,5 \mathrm{~mL}$ de anti-TNF- $\alpha$, por via i.p. nos dias 0 , 6 e 12 de infecção. Animais KO $(n=8)$ e WT $(n=7)$ foram tratados com $\operatorname{IgG}$ normal de rato na mesma concentração e dias como controle adicional. As barras representam as médias \pm EP dos grupos ensaiados. $\mathrm{O}$ asterisco $(*)$ representa diferença estatisticamente significante $(* \mathrm{P}<0,05, * * P<0,01)$. 


\subsection{EFEITO DA DEPLEÇÃO IN VIVO DA CITOCINA TNF- $\alpha$ NAS SUB- POPULAÇÕES DE LINFÓCITOS INFILTRANTES DE PULMÃO DE CAMUNDONGOS iNOS KO E WT}

Como o TNF- $\alpha$ controla a alteração de endotélio e migração celular para focos inflamatórios, consideramos importante o estudo do infiltrado linfocitário nos pulmões dos animais depletados de TNF- $\alpha$ na segunda semana pós-infecção.

A figura 9A mostra que a depleção de TNF- $\alpha$, de maneira surpreendente, resultou em um aumento expressivo do número de linfócitos infiltrantes de pulmão, T CD4 $4^{+}, \mathrm{T} \mathrm{CD} 8^{+}, \mathrm{T}$ $\mathrm{CD} 9^{+}$e $\mathrm{T} \mathrm{CD}^{2} 5^{+}$tanto de animais iNOS KO quanto dos animais WT quando comparados aos seus respectivos controles tratados com IgG normal. Ainda, como visto anteriormente, os animais KO IgG apresentam aumento significante desses linfócitos em relação ao grupo WT IgG.

A depleção de TNF- $\alpha$ resulta em números equivalentes de células nos pulmões de ambas as linhagens, isto é, abole as diferenças de celularidade pulmonar entre os animais normais e iNOS deficientes.

Resultados semelhantes foram observados para os linfócitos ativados duplo positivos $\mathrm{T} \mathrm{CD}^{+} \mathrm{CD} 69^{+}$e $\mathrm{T} \mathrm{CD} 8^{+} \mathrm{CD} 69^{+}$no infiltrado pulmonar de ambas as linhagens tratadas com anti-TNF- $\alpha$ com relação aos controles IgG normal (Figura 9B). Por outro lado, somente o grupo WT tratado resultou em aumento significante de linfócitos $\mathrm{T} C D 4^{+} \mathrm{CD} 25^{+}$nos pulmões em relação ao seu controle WT IgG normal. Os animais KO IgG apresentaram aumento significante dos linfócitos $\mathrm{TCD} 4^{+} \mathrm{CD} 69^{+}$pulmonares comparado ao grupo WT IgG. 
A

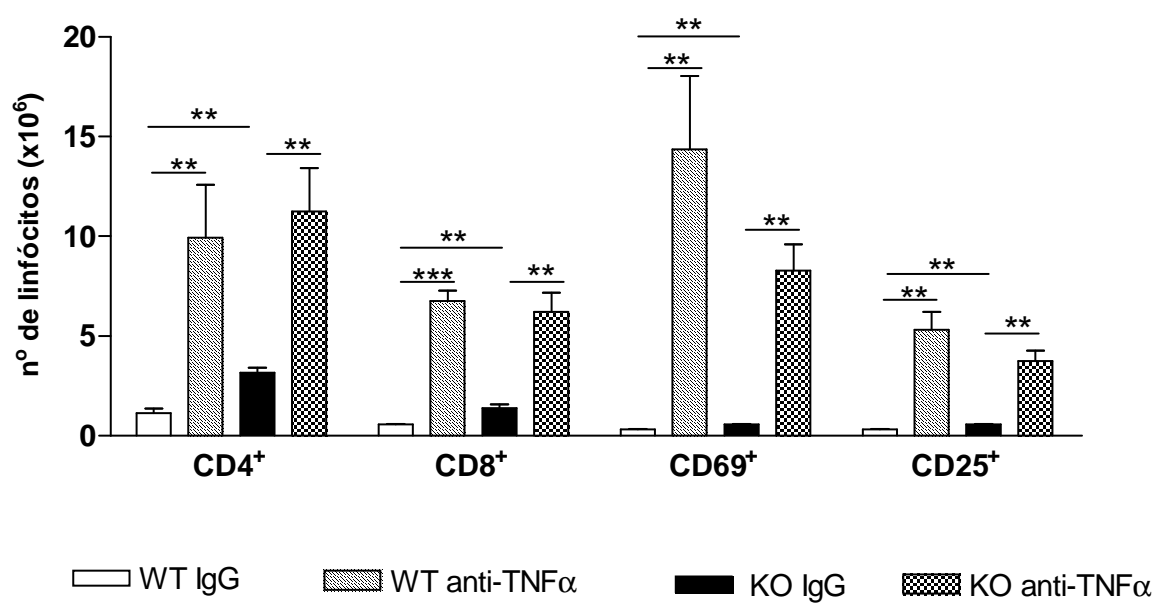

B

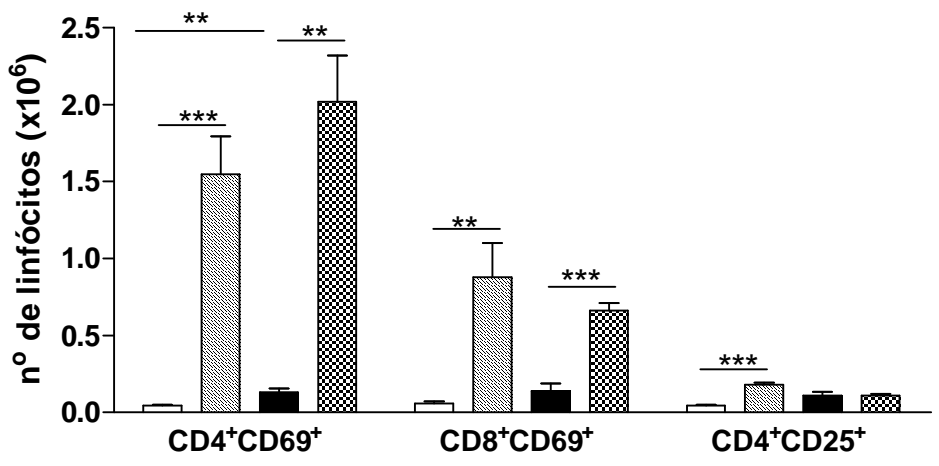

Figura 9. Quantificação de linfócitos $\mathrm{TCD}^{+}, \mathrm{TCD} 8^{+}, \mathrm{TCD} 9^{+}, \mathrm{TCD} 25^{+}$, totais (A) e ativados $\left(\mathrm{CD} 4^{+} \mathrm{CD}^{3} 9^{+}, \mathrm{CD}^{+} \mathrm{CD} 9^{+}, \mathrm{CD} 4^{+} \mathrm{CD} 25^{+}\right)(\mathrm{B})$ presentes nos pulmões de camundongos $\mathrm{KO}$ $(\mathrm{n}=5)$ e seu grupo WT $(\mathrm{n}=5)$ tratados com anti-TNF- $\alpha(250 \mu \mathrm{g} / 0,5 \mathrm{~mL}$, dias 0 , $(-4 \mathrm{~h}$ antes da infecção) e dias 6 e 12 pós infecção) e IgG normal de rato na segunda semana de infecção com $1 \times 10^{6}$ de P. brasiliensis por via i.t.. A expressão de $\mathrm{CD}^{+}, \mathrm{CD} 8^{+}, \mathrm{CD} 69^{+}$e $\mathrm{CD} 25^{+}$foi determinada por citometria de fluxo. O valor absoluto de cada sub-população é apresentado como média \pm EP. $* * P<0,01, * * * P<0,001$ estatisticamente significante. 


\subsection{EFEITO DA DEPLEÇÃO IN VIVO DA CITOCINA TNF- $\alpha$ NOS MACRÓFAGOS INFILTRANTES DE PULMÃO DE CAMUNDONGOS iNOS KO E WT}

A depleção de TNF- $\alpha$ levou ao aumento do infiltrado inflamatório de macrófagos ativados para os pulmões de ambas as linhagens de camundongos na segunda semana de infecção (Figura 10A). Assim, os camundongos iNOS normais, WT, depletados de TNF- $\alpha$ apresentaram em relação aos seus controles tratados com IgG um aumento de células

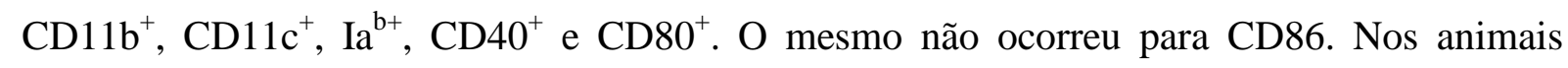
iNOS deficientes depletados apresentaram número aumentado de macrófagos que

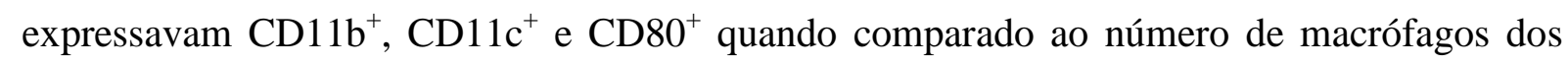
animais $\mathrm{KO}$ IgG. Além disso, estavam também em número aumentado as células duplo

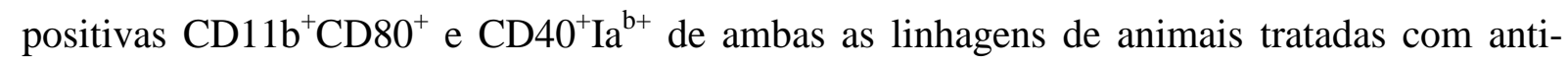
TNF- $\alpha$ com relação às linhagens IgG (Figura 10B). Novamente o marcador CD86 não se apresentou em número mais elevado com a depleção de TNF- $\alpha$. 
A

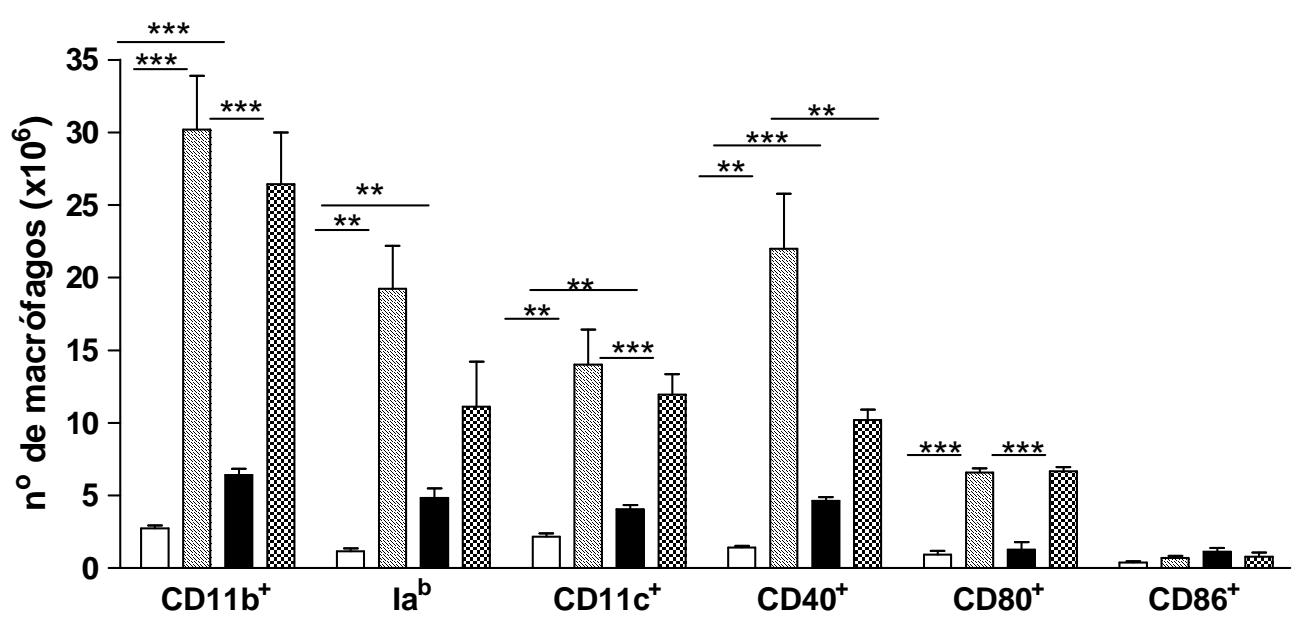

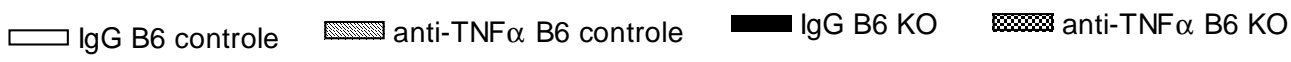

\section{B}

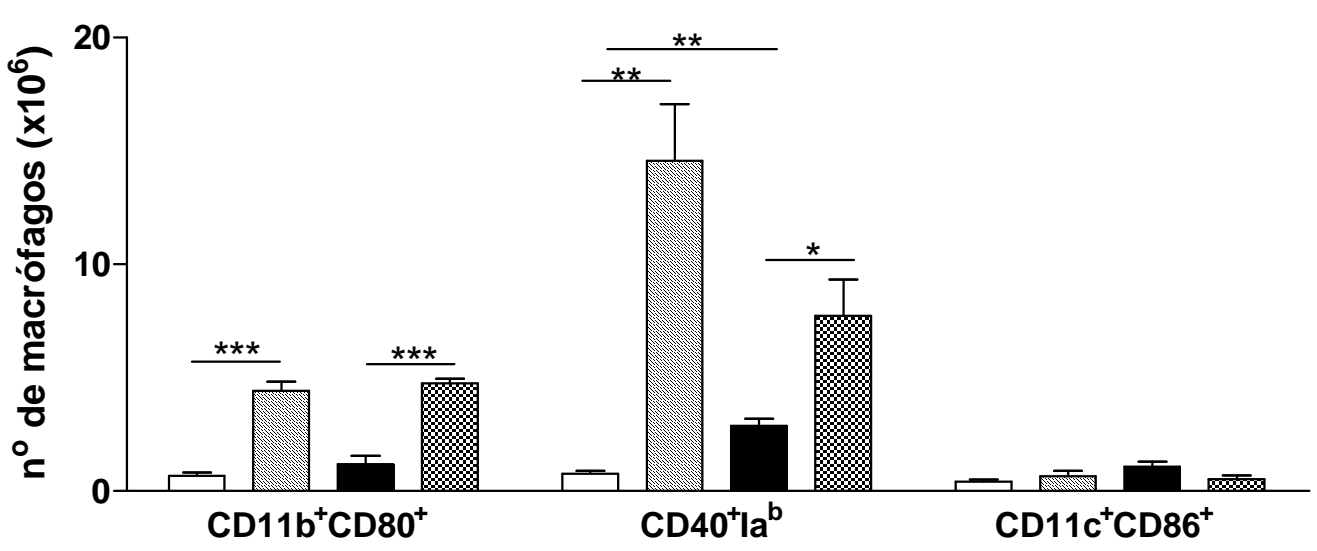

Figura 10. Quantificação de macrófagos infiltrantes de pulmão expressando os marcadores $C D 11 b^{+}$, $\mathrm{Ia}^{\mathrm{b}}, \mathrm{CD} 11 \mathrm{c}^{+}, \mathrm{CD} 40^{+}, \mathrm{CD} 80^{+}$e $\mathrm{CD}^{+} 6^{+}(\mathrm{A})$ e das células duplo positivas $\mathrm{CD} 11 \mathrm{~b}^{+} \mathrm{CD} 80^{+}$, $\mathrm{CD} 40^{+} \mathrm{Ia}^{\mathrm{b}}$ e CD11 $\mathrm{c}^{+} \mathrm{CD}^{2} 6^{+}(\mathrm{B})$, de camundongos $\mathrm{KO}(\mathrm{n}=5)$ e o grupo WT $(\mathrm{n}=5)$ tratados com anti-TNF- $\alpha(250 \mu \mathrm{g} / 0,5 \mathrm{~mL}$, dias 0, (-4h antes da infecção) e dias 6 e 12 pós infecção) ou IgG normal de rato na segunda semana de infecção com 1 × $10^{6}$ de $P$. brasiliensis por via i.t.. A expressão de $\mathrm{CD}_{11} \mathrm{~b}^{+}, \mathrm{Ia}^{\mathrm{b}}, \mathrm{CD} 11 \mathrm{c}^{+}, \mathrm{CD} 40^{+}, \mathrm{CD} 80^{+}$e $\mathrm{CD} 86^{+}$foi determinada por citometria de fluxo. $O$ valor absoluto de cada sub-população é apresentado como média \pm EP. * $P<0,05 * * P<0,01, * * * P<0,001$ estatisticamente significante. 


\subsection{ANÁliSE HISTOPATOLÓGICA DOS PULMÕES DE ANIMAIS iNOS KO E SEU GRUPO WT TRATADOS COM ANTI-TNF-a NA OITAVA SEMANA DE INFECÇÃO}

Um parâmetro adicional para avaliar o papel do TNF- $\square$ na gravidade da doença foi a análise histopatológica dos pulmões dos animais WT e iNOS KO realizada após a oitava semana de infecção pelo $P$. brasiliensis. Como controle, grupo de animais de ambas as linhagens foram tratados com IgG normal (Figura 11). As figuras 11A e 11B mostram os pulmões de animais WT e KO não infectados, respectivamente. Os cortes foram submetidos à coloração por hematoxilina-eosina (H\&E), para identificação celular, e impregnação pela prata metenamina, Groccot, para melhor identificação e localização dos fungos no corte histológico.

A neutralização in vivo de TNF- $\square$ parece não acarretar em grandes alterações nas lesões de animais WT, uma vez que estes camundongos já apresentavam lesões mal organizadas mesmo antes da depleção (Figuras $11 \mathrm{C}, \mathrm{E}$ ); neste grupo observou-se grande quantidade de fungos, os quais, entretanto, aparecem restritos no centro das lesões (Figuras 11 D, F). Nos camundongos WT depletados as lesões aparecem situadas entre os septos interlobulares, peribronquiolares com distribuição irregular pelo parênquima. Não houve formação de granulomas característicos, nem a presença destacada de plasmócitos, neutrófilos ou eosinófilos.

Já os animais KO tratados com IgG normal apresentaram lesões organizadas em granulomas bem formados com intenso afluxo de células inflamatórias as quais parecem controlar a disseminação fúngica nos pulmões (Figuras G, H). Os granulomas apresentam-se grandes e coalescentes localizados nos septos interlobulares em região peribronquiolar. Essas lesões eram constituídas por porção necrótica central com grande quantidade de fungos circundados por células epitelióides, moderado número de células gigantes multinucleadas e um manto de linfócitos. Os fungos visualizados tanto à hematoxilina \& eosina quanto pela coloração de Groccot são grandes, com múltiplas gemulações e eventual aspecto em roda de leme. O processo inflamatório está presente em toda a extensão do corte, mas como já descrito, ocupando preferencialmente os septos interlobulares. Por outro lado, a depleção in vivo de TNF- $\alpha$ nos animais KO resultou em lesões pouco organizadas (Figuras I, J) abolindo o aspecto original de granulomas bem formados e característicos vistos nas lesões pulmonares 
dos animais KO tratados com IgG normal. Aqui, grande quantidade de fungos é vista espalhada por todo o parênquima pulmonar (Figuras 11 I, J). 

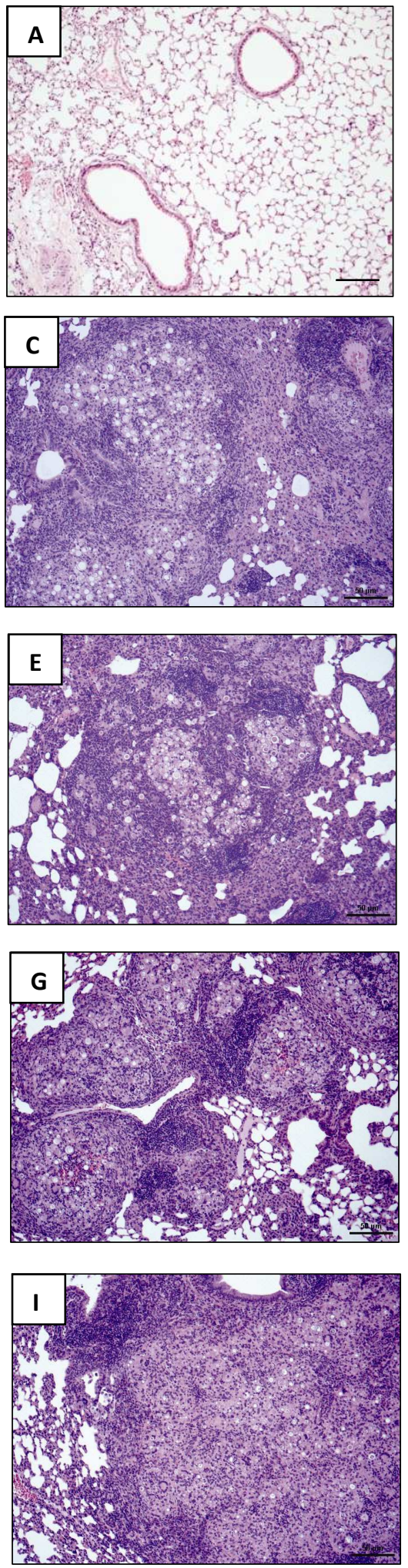
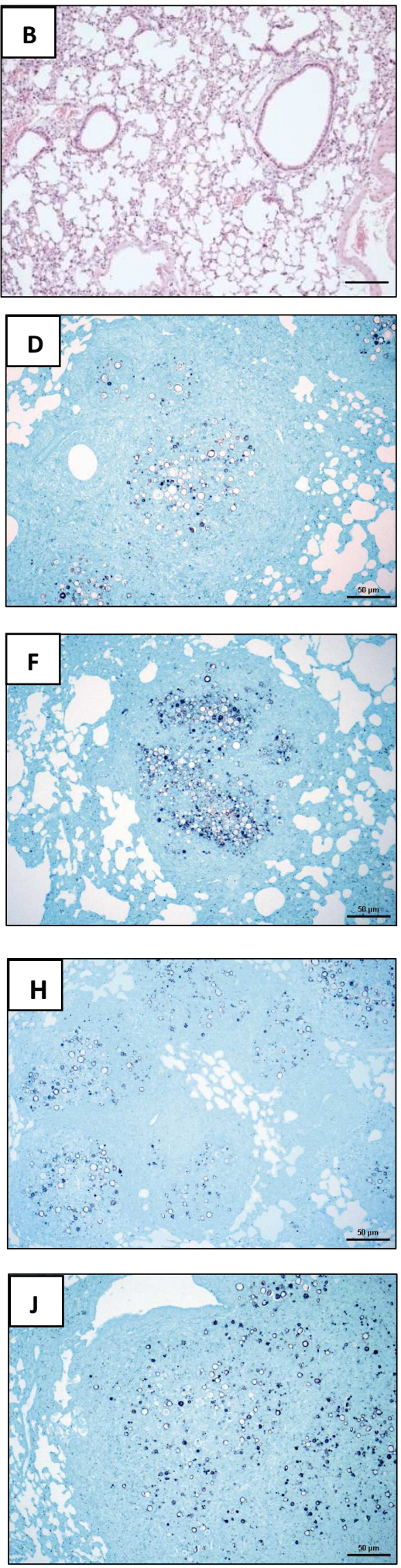

Figura 11. Fotomicrografias de pulmões de animais não infectados (WT: A, KO: B) e de lesões pulmonares de animais C57BL/6 tratados com IgG normal (WT: C,D; KO: G,H) e animais C57BL/6 depletados de TNF- $\alpha$ (WT: E,F; KO: I,J) na oitava semana pós infecção com 1 milhão de leveduras viáveis de $P$. brasiliensis. Em ambas as linhagens tratadas com anti-TNF- $\alpha$ (E,F,I,J) desenvolveram-se lesões pouco organizadas, com grande quantidade de fungos ocupando quase todo o parênquima pulmonar. H\&E (A,B,C,E,G,I) e Groccot (D,F,H,J), (100X). Barras de escalas $=50 \mu \mathrm{m}$. 


\subsection{EFEITO DA DEPLEÇÃO IN VIVO DE LINFÓCITOS T CD8 NA CARGA FÚNGICA PULMONAR DE CAMUNDONGOS iNOS KO E SEU GRUPO WT}

Como anteriormente descrito, verificamos que após 2 semanas de infecção, os animais deficientes de óxido nítrico apresentaram baixa carga fúngica pulmonar (Figura 1A) acompanhada de aumento do número de linfócitos $\mathrm{T} \mathrm{CD}^{+}$(Figura 4) comparado ao grupo WT. Por outro lado, a doença mais grave na décima semana foi associada ao pequeno número de linfócitos $\mathrm{T} \mathrm{CD}^{+}$nas lesões. Estes dados levaram-nos a estudar o efeito da depleção de linfócitos $\mathrm{T} \mathrm{CD}^{+}$na fase aguda do nosso modelo de infecção. Levantamos a hipótese de que os linfócitos $\mathrm{T} \mathrm{CD}^{+}$pudessem ter um papel importante no controle da carga fúngica pulmonar na segunda semana de infecção dos animais deficientes de NO.

O resultado a seguir refere-se ao experimento realizado com a inoculação de $1 \times 10^{6}$ leveduras viáveis de $P$. brasiliensis por via intratraqueal (i.t.) nos animais iNOS KO e WT. Os animais foram tratados ou não com anticorpo monoclonal H-35 purificado, anti-CD8, na concentração de $200 \mu \mathrm{g} / 0,5 \mathrm{~mL}$, via i.p., nas 48 e 24 horas antes da inoculação de leveduras do $P$. brasiliensis e nos dias 6 e 12 pós infecção com $150 \mu \mathrm{g} / 0,5 \mathrm{~mL}$, via i.p.. O grupo controle de ambas as linhagens foi inoculado com IgG normal de rato nos mesmos dias e na mesma concentração protéica do anticorpo monoclonal. Após 2 semanas de infecção foi analisado o número de UFC (pulmão, fígado e baço) dos grupos de animais ensaiados.

A figura 12 mostra que o tratamento com o anticorpo anti-CD8 aboliu a diferença de carga fúngica entre animais KO depletados com relação aos animais WT controle (IgG). O único grupo que permaneceu com valor menor do número de UFC pulmonar foi o KO-IgG comparado ao WT-IgG.

Assim, observamos que o a neutralização de linfócitos T CD8 aumentou a carga fúngica nos pulmões dos animais deficientes de óxido nítrico, demonstrando que essa população linfocitária possui importante papel no controle da carga fúngica pulmonar dos animais KO. Foi observada disseminação para fígado e baço, mas sem diferença estatisticamente significante entre os grupos de animais analisados (dados não mostrados). 


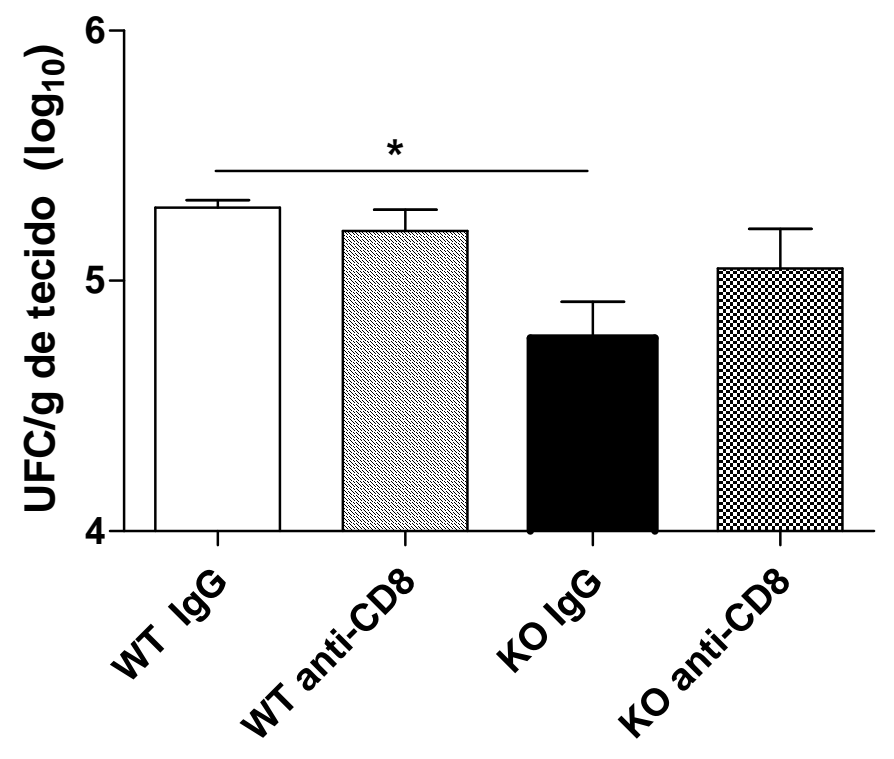

Figura 12. Avaliação da gravidade da doença por contagem do número de Unidades Formadoras de Colônias UFC/g de tecido (em $\left.\log _{10}\right)$ nos pulmões de camundongos KO (n=8) e WT (n=7) após 2 semana de infecção com 1 × $10^{6}$ leveduras de $P$. brasiliensis inoculadas pela via i.t. e tratados pela via i.p. com $200 \mu \mathrm{g} / 0,5 \mathrm{~mL}$ de anti-CD8 (48 e 24 horas antes da inoculação) e $150 \mu \mathrm{g} / 0,5 \mathrm{~mL}$ (dias 6 e 12) após infecção. Animais KO $(\mathrm{n}=8)$ e WT $(\mathrm{n}=7)$ foram tratados com IgG normal de rato na mesma concentração e dias como controle adicional. As barras representam as médias $\pm \mathrm{EP}$ dos grupos ensaiados. $\mathrm{O}$ asterisco $\left(^{*}\right)$ representa diferença significante $(* \mathrm{P}<0,05)$. 


\subsection{EFEITO DA DEPLEÇÃO IN VIVO DE LINFÓCITOS T CD8 NOS LINFÓCITOS INFILTRANTES DE PULMÃO DE CAMUNDONGOS iNOS KO E SEU GRUPO WT}

Ao contrário do que ocorreu com a depleção de TNF- $\alpha$, a depleção in vivo de linfócitos $\mathrm{T} \mathrm{CD}^{+}$resultou em redução significativa de todas as sub-populações $\mathrm{T}$ nos pulmões dos animais deficientes de oxido nítrico, enquanto que somente alterou a subpopulação T CD8 nos animais iNOS normais. Assim, a figura 13 A mostra que para os animais KO depletados essa diminuição celular pôde ser observada para os linfócitos T CD4 ${ }^{+}$, $\mathrm{T} \mathrm{CD}^{+}$e para os linfócitos ativados expressando $\mathrm{CD} 69^{+}$e $\mathrm{CD} 25^{+}$. O grupo WT depletado de CD8 apresentou somente redução do infiltrado de linfócitos T CD8 ${ }^{+}$em relação ao grupo WT controle (IgG normal). Ainda na figura 13A pode-se verificar que o infiltrado de células pulmonares $\left(\mathrm{T} \mathrm{CD}^{+}, \mathrm{T} \mathrm{CD}^{+}\right.$e $\mathrm{T} \mathrm{CD}^{+} 9^{+}$) continua aumentado nos animais $\mathrm{KO}$ IgG quando comparados aos do grupo WT IgG. Somente a população de linfócitos CD25 $5^{+}$mostrou-se aumentada no infiltrado pulmonar dos animais WT anti-CD8 comparados aos KO também depletado de CD8.

Quando analisamos as populações duplo positivas de linfócitos, (Figura 13B), o infiltrado pulmonar dos animais $\mathrm{KO}$ tratados com anti-CD8 mostrou número reduzido das populações $\mathrm{T} \mathrm{CD}^{+} \mathrm{CD}^{+} 9^{+}$e $\mathrm{T} \mathrm{CD} 8^{+} \mathrm{CD} 69^{+}$com relação aos animais $\mathrm{KO}$ IgG. Já nos animais iNOS normais, essa depleção reduziu o número de linfócitos T $\mathrm{CD}^{+} \mathrm{CD}_{6} 9^{+}$e $\mathrm{T} \mathrm{CD} 4^{+} \mathrm{CD} 25^{+}$, em relação ao grupo tratado com IgG. As células com marcador de ativação $\mathrm{CD}^{+} 9^{+}$para $\mathrm{CD}^{+}$e $\mathrm{CD}^{+}$continuam aumentadas nos animais $\mathrm{KO}$ IgG quando comparados aos WT IgG. $\mathrm{E}$, ainda, os linfócitos $\mathrm{T} \mathrm{CD} 4^{+} \mathrm{CD} 69^{+}$encontram-se em número reduzido nos animais $\mathrm{KO}$ tratados com anti-CD8 em relação ao grupo WT também depletado. 

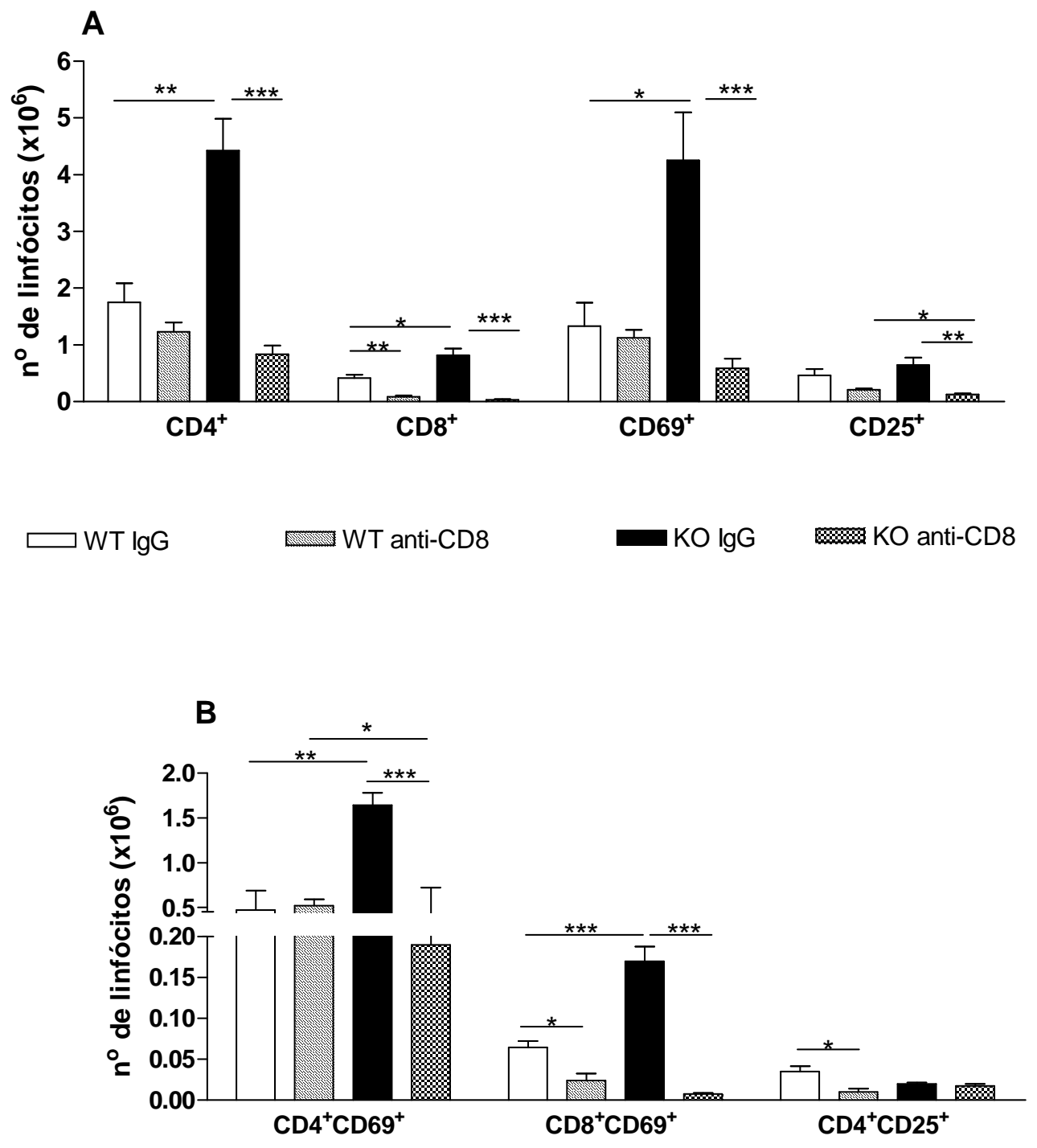

Figura 13. Quantificação de linfócitos $\mathrm{TCD}^{+}, \mathrm{TCD} 8^{+}, \mathrm{TCD} 9^{+}, \mathrm{TCD} 25^{+}$, totais (A) e ativados $\left(\mathrm{CD} 4^{+} \mathrm{CD} 69^{+}, \mathrm{CD} 8^{+} \mathrm{CD} 69^{+}, \mathrm{CD} 4^{+} \mathrm{CD} 25^{+}\right)$(B) presentes nos pulmões de camundongos KO $(n=5)$ e seu grupo WT $(n=5)$ tratados com anti-CD8 $(250 \mu \mathrm{g} / 0,5 \mathrm{~mL},-48$ e $-24 \mathrm{~h}$ antes da infecção e $150 \mu \mathrm{g} / 0,5 \mathrm{~mL}$, dias 6 e 12 pós infecção) e IgG normal de rato na segunda semana de infecção com $1 \times 10^{6}$ de $P$. brasiliensis por via i.t.. A expressão de $\mathrm{CD}^{+}$, $\mathrm{CD}^{+}, \mathrm{CD} 9^{+}$e $\mathrm{CD} 25^{+}$foi determinada por citometria de fluxo. O valor absoluto de cada sub-população é apresentado como média \pm EP. $* P<0,05$, ** $P<0,01, * * * P<0,001$ estatisticamente significante. 


\subsection{EFEITO DA DEPLEÇÃO IN VIVO DE LINFÓCITOS T CD8 NOS MACRÓFAgOS INFILTRANTES DE PULMÃO DE CAMUNDONGOS iNOS KO E SEU GRUPO WT}

A figura 14A mostra que o tratamento com anticorpo anti-CD8, resultou em uma diminuição significativa no infiltrado de macrófagos pulmonares somente dos camundongos deficientes de óxido nítrico e não do grupo iNOS normais na segunda semana pós-infecção.

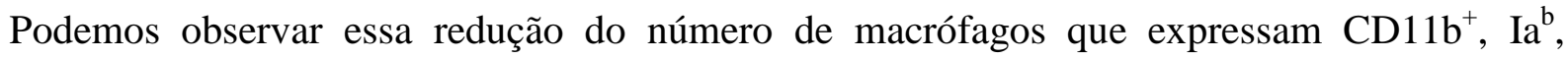
$\mathrm{CD} 11 \mathrm{c}^{+} \mathrm{CD}^{+} 0^{+}, \mathrm{CD}^{+} 0^{+}$e $\mathrm{CD}^{+} 6^{+}$nos animais $\mathrm{KO}$ tratados com anti-CD8 comparado ao grupo KO IgG. Ainda nesta figura podemos verificar o menor número de células expressando estes marcadores, com exceção de $\mathrm{CD}^{+} 0^{+}$, nos animais $\mathrm{KO}$ em relação aos WT, ambos depletados de anti-CD8.

Já o estudo dos macrófagos duplo positivos demonstrou que as células $\mathrm{CD} 11 \mathrm{~b}^{+} \mathrm{CD} 80^{+}$, $\mathrm{CD} 40^{+} \mathrm{Ia}^{\mathrm{b}}$ e $\mathrm{CD} 11 \mathrm{c}^{+} \mathrm{CD} 86^{+}$, continuam reduzidas nos animais deficientes de NO tratados com anticorpo anti-CD8 em relação aos $\mathrm{KO}$ tratados com IgG normal. Esses animais KO depletados continuavam apresentando redução das células $\mathrm{CD}_{40}{ }^{+} \mathrm{Ia}^{\mathrm{b}}$ e $\mathrm{CD} 11 \mathrm{c}^{+} \mathrm{CD} 86^{+}$, em relação ao grupo WT também depletado (Figura 14 B). 

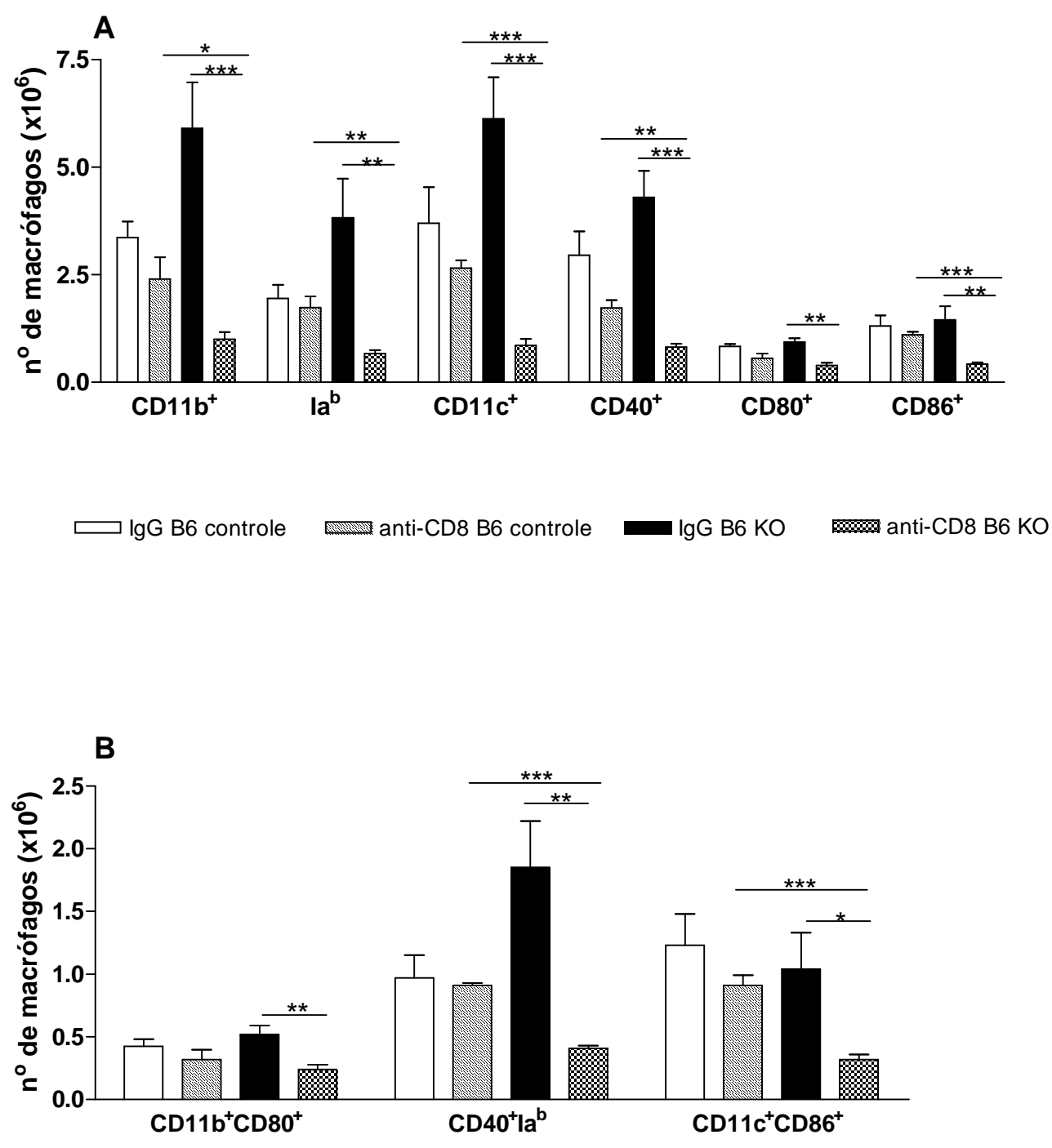

Figura 14. Quantificação dos macrófagos infiltrantes de pulmão expressando os marcadores CD11 $b^{+}$, $\mathrm{Ia}^{\mathrm{b}}, \mathrm{CD} 11 \mathrm{c}^{+}, \mathrm{CD} 40^{+}, \mathrm{CD} 80^{+}$e CD86 $6^{+}(\mathrm{A})$ e das células duplo positivas $\mathrm{CD} 11 \mathrm{~b}^{+} \mathrm{CD} 80^{+}$, $\mathrm{CD} 40^{+} \mathrm{Ia}^{\mathrm{b}}$ e CD11 $\mathrm{c}^{+} \mathrm{CD} 86^{+}(\mathrm{B})$, de camundongos $\mathrm{KO}(\mathrm{n}=5)$ e seu grupo WT $(\mathrm{n}=5)$ tratados com anti-CD8 $(250 \mu \mathrm{g} / 0,5 \mathrm{~mL},-48 \mathrm{e}-24 \mathrm{~h}$ antes da infecção e $150 \mu \mathrm{g} / 0,5 \mathrm{~mL}$, dias 6 e 12 pós infecção) e IgG normal de rato na segunda semana de infecção com 1 x $10^{6}$ de $P$.

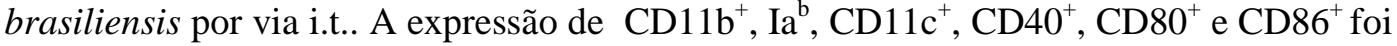
determinada por citometria de fluxo. $O$ valor absoluto de cada sub-população é apresentado como média \pm EP. $* P<0,05, * * P<0,01, * * * P<0,001$ estatisticamente significante. 


\section{DISCUSSÃO}

Nosso estudo com animais deficientes da enzima óxido nítrico sintase induzida (iNOS KO), responsável pela produção de óxido nítrico que é uma importante molécula microbicida contra inúmeros patógenos, demonstrou que estes animais desenvolviam comportamentos opostos no curso da infecção pelo Paracoccidioides brasiliensis. Na fase aguda, na segunda semana de infecção, os animais iNOS KO mostraram uma menor carga fúngica pulmonar quando comparada ao grupo controle. Além disso, os níveis de TNF- $\alpha$ estavam aumentados nos pulmões destes animais deficientes de iNOS. Assim, havia a sugestão de que a citocina próinflamatória $\mathrm{TNF}-\alpha$ poderia compensar a ausência de uma importante molécula microbicida para a eliminação do $P$. brasiliensis. Trabalhos realizados anteriormente em nosso laboratório mostraram que animais resistentes ao $P$. brasiliensis produziam altos níveis de TNF- $\alpha$ e baixos níveis de NO, enquanto que animais susceptíveis apresentavam comportamento contrário ao dos animais resistentes. Ainda neste trabalho, utilizando um inibidor da síntese de NO, a aminoguanidina, verificou-se que a mesma induzia o aumento dos níveis de TNF- $\alpha$ produzidos por macrófagos peritoneais de animais suscetíveis (NASCIMENTO et al., 2002).

No decorrer da doença, na sexta semana de infecção, observamos que a carga fúngica pulmonar dos animais NO-deficientes foi equivalente à do grupo controle, demonstrando que com o tempo, a presença de óxido nítrico parece ser importante para conter o crescimento fúngico.

Já na fase crônica da infecção, na décima semana, entretanto, a ausência de NO propiciou a reversão do quadro da doença observado nas segunda e sexta semanas, e determinou carga fúngica pulmonar maior que a dos animais controle. Neste momento a citocina TNF- $\alpha$, que antes encontrava-se aumentada nos pulmões dos animais KO, encontrase em níveis pulmonares semelhantes em ambos os grupos. Assim, verificamos que no decorrer da PCM pulmonar o óxido nítrico parece ser dispensável para o controle da carga fúngica nos pulmões na fase aguda da doença, porém importante nos momentos mais tardios onde essa deficiência levou a infecção mais grave. Além disso, pudemos observar também que a doença menos grave era relacionada à presença de níveis aumentados de TNF- $\alpha$ pulmonar, e no quadro mais grave da infecção essa citocina mostrou-se equivalente nos pulmões de ambos os animais. 
Resultados semelhantes ao nosso modelo de infecção aguda mostraram, na segunda semana de infecção pelo Sporotrix schenkii, que a doença era menos grave com menor número de UFC nos pulmões e níveis elevados de TNF- $\alpha$ pulmonar nos animais iNOS KO comparado ao grupo controle. Ainda, a ausência de NO era associada ao aumento da proliferação celular e diminuição do número de células apoptóticas com relação aos animais iNOS normais (FERNANDES et al., 2008). No modelo de infecção aguda pelo $M$. tuberculosis, a deficiência de NO levou à doença menos grave além de níveis aumentados de IFN- $\gamma$ no plasma dos animais deficientes (MACMICKING et al., 1997). Trabalho desenvolvido por Millar et al. (1999) mostrou que animais iNOS KO infectados por T. brucei apresentavam menor parasitemia a partir do quarto dia de infecção, níveis aumentados de IFN- $\gamma$ em células esplênicas, e aumento da resposta linfoproliferativa quando comparado aos animais controle. Estudos adicionais relativos ao comportamento de animais deficientes de iNOS mostraram na infecção por $M$. avium, mais uma vez, menor número de UFC nos pulmões, níveis elevados de IFN- $\gamma$ sérico, aumento de células T $\mathrm{CD}^{+}$esplênicas em animais deficientes de NO em relação aos animais normais (GOMES et al., 1999). Assim, vários estudos com diferentes agentes infecciosos mostraram que no início da infecção parece haver mecanismos compensatórios para a eliminação do patógeno independentes da atividade microbicida atribuída ao óxido nítrico.

Em recente trabalho, Carmo et al. (2006) mostraram que monócitos humanos, infectados pelo $P$. brasiliensis e ativados com TNF- $\alpha$, apresentavam maior atividade fungicida do que as células não ativadas por TNF- $\alpha$ e que este mecanismo era dependente da produção de radicais de oxigênio, $\mathrm{H}_{2} \mathrm{O}_{2}$, e não de óxido nítrico, uma vez que a inibição do peróxido de hidrogênio pela catalase reduzia a atividade fungicida desses monócitos. Níveis pouco significativos na redução da capacidade fungicida foram atribuídos ao óxido nítrico quando se utilizou um inibidor da enzima iNOS, o $\mathrm{N}^{\mathrm{G}}$-MMLA. O mesmo comportamento microbicida diante ao $P$. brasiliensis foi visto com neutrófilos polimorfonucleares humanos, que apresentavam melhor atividade fungicida quando ativados por IFN- $\gamma$, TNF- $\alpha$ ou GM-CSF e essa atividade fungicida era abolida quando se adicionavam inibidores da ação dos metabólitos do oxigênio, ou seja, a catalase (quebra de $\mathrm{H}_{2} \mathrm{O}_{2}$ ) e superóxido dismutase (bloqueio dos ânions superóxido $\mathrm{O}_{2}^{-}$) (RODRIGUES et al., 2007). Em concordância, Gonzalez et al. (2004) mostraram que macrófagos peritoneais de animais infectados por $P$. brasiliensis, ativados in vitro com TNF- $\alpha$, apresentavam mecanismo fungicida independente do óxido nítrico e que o TNF- $\alpha$ era importante mediador na inibição da transição da fase de conídio (não infectante) para a fase leveduriforme (patogênica) do fungo. 
Em modelo de infecção pelo $H$. capsulatum mostrou-se que os monócitos humanos apresentavam melhor atividade fungicida quando ativados com IFN- $\gamma$, e que a mesma era dependente da ação dos ânions superóxido (BRUMMER et al., 1991).

Um mecanismo compensatório, in vivo, no controle inicial do T. gondii foi atribuído à presença e ação dos PMN nos animais iNOS KO, uma vez que o uso do anticorpo monoclonal anti-PMN diminuía a sobrevida destes animais. Na fase crônica, por outro lado, os animais KO apresentavam menor sobrevida devido ao aumento do número de cistos no cérebro, infecção e necrose exacerbada, demonstrando assim a importância do NO no controle e disseminação da doença na fase crônica (SCHARTON-KERSTEN et al., 1997).

Em elegante trabalho, Bocca et al. (1998) mostraram que o tratamento com inibidor da iNOS, Nitro-Arg, levou à maior proliferação de linfócitos esplênicos e níveis aumentados de TNF- $\alpha$ do sobrenadante de cultura de macrófagos peritoneais e broncoalveolares. Na décima semana de infecção pelo $P$. brasiliensis, apesar da maior carga fúngica pulmonar observada nesses animais tratados, a área das lesões pulmonares era menor e organizada em granulomas pequenos e coalescentes que continham a grande carga fúngica no sítio primário da infecção.

Se o óxido nítrico é dispensável nos primeiros momentos da doença, como vimos no nosso modelo e em vários outros de infecção, no período mais tardio, a ausência de NO leva à falta do controle de crescimento do patógeno. Assim, podemos observar um efeito temporal da importância do óxido nítrico em diferentes fases da infecção.

Para melhor entender nosso modelo experimental, consideramos importante o estudo da atividade fungicida dos macrófagos alveolares de animais deficientes de NO, durante as segunda e décima semanas de infecção. Nossos estudos in vitro com macrófagos alveolares, de animais de ambas as linhagens na segunda semana de infecção, mostraram mais uma vez menor número de fungos recuperados das vias aéreas de animais deficientes de NO, comparado ao grupo controle. Por outro lado, a deficiência de óxido nítrico resultou na ausência de aumento na atividade fungicida dos macrófagos quando ativados com IFN- $\gamma$. O mesmo comportamento foi observado quando feito um novo desafio com P. brasiliensis na cultura desses macrófagos alveolares. Como esperado, não foi detectada a produção de NO pelos macrófagos de animais iNOS-deficientes. Assim, considerando o menor número de fungos recuperados dos macrófagos de animais $\mathrm{KO}$, e ainda o menor número de UFC obtido in vivo, propusemo-nos a investigar a participação de radicais de oxigênio que poderiam ter um papel importante no controle da carga fúngica na fase aguda da infecção. Deste modo, os macrófagos alveolares obtidos do lavado broncoalveolar de animais NO-deficientes produziam grande quantidade de peróxido de hidrogênio, com ou sem o estímulo de PMA, em 
relação às células dos animais iNOS normais. Assim, a deficiência de NO in vivo poderia resultar em mecanismos compensatórios para a atividade fungicida destes macrófagos como a produção de $\mathrm{H}_{2} \mathrm{O}_{2}$ que poderia ter participado no controle da carga fúngica na fase aguda do nosso modelo.

Já os macrófagos de animais controle, entretanto, além de apresentarem aumento da atividade microbicida contra o fungo, produziram níveis elevados de óxido nítrico quando ativados com IFN- $\gamma$; além disso, demonstravam atividade fungicida e produção de NO aumentados quando desafiados com $P$. brasiliensis em presença de IFN- $\gamma$. Assim, os macrófagos alveolares que mostraram maior atividade fungicida in vitro foram os que produziram níveis elevados de NO, aqueles dos animais iNOS-normais e ainda mais, foram esses macrófagos os únicos ativáveis por IFN- $\gamma$.

No estudo da atividade fungicida in vitro na fase crônica da doença, observamos mais uma vez um maior número de fungos recuperados dos macrófagos de animais $\mathrm{KO}$ comparado ao dos animais controle, resultado paralelo ao número de UFC recuperado in vivo na décima semana de infecção. Aqui o estudo do mecanismo fungicida in vitro, como na segunda semana de infecção, mostrou que os macrófagos alveolares de animais iNOS normais são os que apresentam melhor atividade fungicida frente ao $\mathrm{Pb}$ quando ativados pelo IFN- $\gamma$ concomitante com aumento dos níveis de NO.

A menor atividade fungicida in vitro dos macrófagos de animais iNOS KO pôde ser atribuída à menor atividade intrínseca das células, ao contrário da infecção in vivo onde, além da produção aumentada de peróxido de hidrogênio dos macrófagos, ocorre também o recrutamento de outras populações celulares para o sítio da infecção. Além disso, in vitro, os macrófagos não recebem todos os estímulos que podem ocorrer in vivo e talvez necessitem de outros mecanismos acessórios, independente do NO, para o controle do patógeno.

Recentemente, Konno et al. (2009) mostraram que a adição de peptídeos que compunham a glicoproteína gp43 do P. brasiliensis, os quais tinham importante papel no mecanismo de evasão do fungo, na cultura de macrófagos murinos de medula óssea e infectados pelo $P$. brasiliensis apresentavam menor índice de fagocitose in vitro com níveis diminuídos de $\mathrm{NO}$ e aumentados de $\mathrm{H}_{2} \mathrm{O}_{2}$ com relação a cultura de macrófagos sem esses inibidores. Assim, sugeriram que a melhor atividade fungicida dos macrófagos frente ao $\mathrm{Pb}$ seria mediado pela presença de radicais de nitrogênio.

Nosso laboratório mostrou recentemente que os macrófagos alveolares de animais suscetíveis ao $P$. brasiliensis eram os que apresentavam eficiente atividade fungicida concomitante com níveis elevados de NO, sendo que os macrófagos de animais resistentes 
tinham baixa atividade fungicida, pouca produção de NO e altos níveis de TGF- $\beta$ (PINA et al., 2008).

Fernandes et al. (2008) mostraram resultados semelhantes aos nossos no estudo com o animais iNOS KO com 2 semanas de infecção pelo Sporothrix schenckii, no qual os macrófagos desses animais apresentavam atividade microbicida deficiente contra o fungo quando comparado aos macrófagos de animais controle. Ainda, os macrófagos de animais controle também produziam níveis aumentados de NO. A presença de óxido nítrico, entretanto, foi relacionada à maior apoptose celular e imunossupressão com redução da proliferação celular.

Assim, o óxido nítrico é importante como molécula microbicida, porém a sua produção contínua ou exagerada para a eliminação do patógeno leva à imunossupressão (BOCCA et al., 1998; DALTON et al., 2000; VEEN et al., 2000; FERNANDES et al., 2008).

Apesar da ausência do mecanismo microbicida atribuído ao NO, outros mecanismos NO-independentes poderiam estar atuando na fase aguda da infecção para o controle do crescimento fúngico. É importante lembrar o mecanismo microbicida mediado pela enzima indolamina 2,3 dioxigenase, IDO, presente em vários tipos celulares, como macrófagos, células dendríticas, linfócitos T CD4 e B, células NK. Esta enzima é responsável pela degradação do aminoácido triptofano em kirunenina, o qual é essencial para a síntese protéica e sobrevivência de vários tipos de patógenos. Quando ativada por IFN- $\gamma$, a ação da IDO pode resultar em supressão da resposta linfoproliferativa, aumento dos níveis de células apoptóticas e na indução da geração de células $\mathrm{T}$ reguladoras ao invés de $\mathrm{T}$ efetoras (MULLEY e NIKOLIC-PATERSON, 2008). Vale lembrar que o NO tem sido demonstrado como inibidor da atividade da IDO (THOMAS et al., 1994).

A relação NO e IDO foi demonstrada na infecção pelo $T$. gondii quando se utilizou um inibidor da iNOS, o L-NAME, e foi observado aumento dos níveis plasmáticos de kirunenina nos animais infectados em relação aos animais não tratados, mostrando assim a ação compensatória da IDO na tentativa de eliminar o patógeno na ausência da iNOS (FUJIGAKI et al., 2002).

Além dos mecanismos mediados pela enzima IDO, vimos que na fase aguda do nosso modelo de infecção, os macrófagos alveolares de animais iNOS KO produzem níveis elevados de peróxido de hidrogênio, o que poderia ter sido também responsável pelo melhor controle da carga fúngica pulmonar in vivo desses animais. Moreira et al. (2008), mostraram que os macrófagos peritoneais murinos ativados por IFN- $\gamma$ e TNF- $\alpha$ exibiam melhor atividade fungicida contra o $P$. brasiliensis e que a mesma era dependente da ação de $\mathrm{H}_{2} \mathrm{O}_{2}$ e $\mathrm{NO}$. 
Meloni-Bruneri et al. (1996) mostraram no modelo murino da PCM que as células PMN de animais resistentes ao fungo eram as que produziam maiores níveis de $\mathrm{H}_{2} \mathrm{O}_{2}$ comparadas às dos animais suscetíveis. O peróxido de hidrogênio foi considerado importante molécula fungicida na infecção pelo P. brasiliensis, produzida tanto por macrófagos (CARMO et al., 2006), quanto por neutrófilos (RODRIGUES et al., 2007), bem como no modelo de infecção por $C$. albicans (WATANABE et al., 1991) e de H. capsulatum (WOLF et al., 1989).

Os nossos dados indicavam a importância, para o entendimento do nosso modelo experimental, da análise das sub-populações celulares de linfócitos infiltrantes de pulmão de animais $\mathrm{KO}$ e controle, bem como do perfil fenotípico de macrófagos alveolares, tanto na fase aguda, como na fase crônica da infecção. Verificamos a presença nos animais $\mathrm{KO}$, tanto nas 2 e 10 semanas, de grande número de linfócitos $\mathrm{T} \mathrm{CD}^{+}$, a maioria em estado ativado como demonstrado pelo aumento da expressão do marcador de ativação precoce $\operatorname{CD}^{+} 9^{+}$e do marcador $\mathrm{CD}_{25} 5^{+}$(cadeia $\alpha$ do receptor de IL-2, expresso em células $\mathrm{T}$ ativadas e ainda um dos marcadores de células T reguladoras).

Nas 2 semanas de infecção encontramos no infiltrado pulmonar, além do aumento de células $\mathrm{T}$ ativadas, maior número de macrófagos expressando marcadores de ativação o que sugere a participação destas células nos mecanismos de proteção de animais KO.

Como no nosso modelo de infecção por P. brasiliensis, Millar et al. (1999) mostraram que camundongos deficientes da síntese de óxido apresentaram aumento do número de lintócitos T $\mathrm{CD} 4{ }^{+} \mathrm{CD} 25^{+}$esplênicos durante a infecção por $T$. brucei.

Em recente trabalho, nosso laboratório mostrou o papel atribuído aos linfócitos $\mathrm{T}$ $\mathrm{CD}^{+}$no padrão de suscetibilidade e resistência à infecção pelo $P$. brasiliensis uma vez que em animais resistentes $(\mathrm{A} / \mathrm{J})$ a depleção dessas células gerava reposta suprimida de HTT (hipersensibilidade do tipo tardio) nas 4 e 8 semanas de infecção, diminuição da produção de anticorpos IgG2a, IgG1 e IgG2b e dos níveis da citocina IL-2. Entretanto, a ausência desses linfócitos pouco alterava a carga fúngica pulmonar, e não diminuía a sobrevida desses animais. Nos animais suscetíveis, por outro lado, o tratamento com anticorpo anti-CD4 não alterou a doença uma vez que os linfócitos $\mathrm{T} \mathrm{CD}^{+}$apresentam-se em anergia desde o início da doença (CHIARELLA et al., 2007).

A análise da sub-população $\mathrm{T} \mathrm{CD}^{+} \mathrm{CD} 25^{+}$mostrou que os animais deficientes de óxido nítrico apresentavam expressivo aumento das mesmas no infiltrado pulmonar nas 2 e 10 semanas de infecção. Deste modo, os animais KO apresentaram além do aumento do número de linfócitos $\mathrm{T} \mathrm{CD}^{+} \mathrm{CD} 69^{+}$(marcador de ativação precoce), aumento também do número de linfócitos $\mathrm{T} \mathrm{CD} 4^{+} \mathrm{CD} 25^{+}$infiltrantes de pulmão. Assim, parece que a ausência de óxido nítrico 
resulta em maior infiltrado de linfócitos $\mathrm{T}$ ativados o que poderia proporcionar uma resposta imune celular mais eficiente contra o P. brasiliensis na segunda semana de infecção. Embora na décima semana de infecção tenhamos obtido maior carga fúngica pulmonar nos animais deficientes de NO, observamos ainda um número aumentado de células T CD4 ${ }^{+}$ativadas (T $\mathrm{CD} 4^{+} \mathrm{CD} 69^{+}, \mathrm{T} \mathrm{CD}^{+} \mathrm{CD} 25^{+}$) no pulmão desses animais, embora em menor grau que aquela observada na fase aguda da doença. Vale lembrar que neste período foi observada a formação de grandes granulomas que parecem refletir a melhor resposta imune da segunda semana de infecção e onde o TNF- $\alpha$ estaria exercendo efeito preponderante. Esses granulomas foram capazes de conter o fungo no foco primário da infecção e, mais ainda, os estudos de mortalidade mostraram que ambos os grupos de animais, $\mathrm{KO}$ e controle, morriam em tempos equivalentes. Assim, a ausência de NO parece ser compensada pela melhor resposta imune celular que levaria à melhor organização dos granulomas.

De modo semelhante aos linfócitos $\mathrm{T} \mathrm{CD}^{+}$, obtivemos, na fase aguda, expressivo aumento das células $\mathrm{T} \mathrm{CD} 8^{+}$nos animais iNOS KO e, ainda, a grande parte desses linfócitos apresentava-se ativada, apresentando o fenótipo $\mathrm{T} \mathrm{CD} 8{ }^{+} \mathrm{CD} 69^{+}$. Podemos então supor que os linfócitos $\mathrm{T} \mathrm{CD}^{+}$exerçam papel protetor na PCM reduzindo a carga fúngica nos camundongos iNOS KO. O papel dessas células citotóxicas efetoras baseia-se na produção de enzimas como perforinas e granzimas que acabam por destruir células infectadas, reduzindo o foco infeccioso (BARBER et al., 2003). Podem também ser protetoras através da síntese de IFN- $\gamma$ e ativação da atividade efetora eficiente dos fagócitos. Trabalho realizado em nosso laboratório mostrou a importância dos linfócitos T CD8 na redução da carga fúngica pulmonar e controle da disseminação para fígado e baço de animais resistentes e suscetíveis ao P. brasiliensis (CANO et al., 2000).

Outro trabalho também desenvolvido em nosso laboratório mostrou que a depleção de linfócitos $\mathrm{T} \mathrm{CD}^{+}$gerou aumento na carga fúngica pulmonar, durante a oitava semana pós infecção, tanto de animais resistentes, quanto de animais suscetíveis. Animais CD8-KO apresentaram sobrevida inferior aos CD4 KO e WT, além de grande número de UFC, nas 12 semanas de infecção, nos pulmões, fígado e baço (CHIARELLA et al., 2007). Assim, na PCM estas células parecem exercer grande efeito protetor. No trabalho de Chiarella et al. (2007) verificou-se também que linfócitos $\mathrm{T} \mathrm{CD}^{+}$estão envolvidos com a síntese de IFN- $\gamma$; esta citocina poderia contribuir com a proteção através da ativação de macrófagos que exerceriam efeito fungicida independente da síntese de NO.

$\mathrm{Na}$ fase crônica do nosso modelo, onde há maior carga fúngica pulmonar nos animais deficientes de NO, obtivemos números semelhantes de linfócitos T CD8 para ambos os 
grupos de animais estudados. Como citado anteriormente, os linfócitos T $\mathrm{CD}^{+}$têm importância na proteção contra a PCM, e a sua presença em pequeno número no infiltrado linfocitário pulmonar de 10 semanas, poderia levar a uma maior carga fúngica nos pulmões.

Na PCM humana, Mamoni et al. (2006) verificaram que os pacientes que eram infectados pelo $P$. brasiliensis, mas que não apresentavam os sintomas e portanto resolviam a doença, eram os que tinham aumento do número de linfócitos T CD8 os quais eram a principal fonte da citocina IFN- $\gamma$. Já as citocinas TNF- $\alpha$ e IL-2 mostraram ser provenientes de linfócitos T CD4.

É importante enfatizar a importância dos linfócitos $\mathrm{T} C D 8^{+}$, já que encontramos baixa frequência de PCM em pacientes aidéticos (GOLDANI e SUGAR, 1995). Como na AIDS ocorre redução do número de linfócitos $\mathrm{T} \mathrm{CD}^{+}$, infectados pelo vírus $\mathrm{HIV}$, poderia haver um predomínio de linfócitos $\mathrm{T} \mathrm{CD}^{+}$que acabariam por proteger esses pacientes contra a PCM, já que os linfócitos $\mathrm{T} \mathrm{CD}^{+}$parecem exercer papel protetor contra o fungo.

Em conclusão, nosso modelo na fase aguda da infecção mostrou que a ausência de NO resulta em um aumento do infiltrado inflamatório de linfócitos $\mathrm{T}$, sendo a sua maioria ativados $\left(\mathrm{T} \mathrm{CD}^{+} \mathrm{CD}^{+} 9^{+}, \mathrm{T} \mathrm{CD} 4^{+} \mathrm{CDC} 25^{+}, \mathrm{T} \mathrm{CD}^{+} \mathrm{CD} 69^{+}\right)$.

Lindel et al. (2006) mostraram na infecção pulmonar por C. neoformans que o aumento de linfócitos $\mathrm{T}$ ativados era atribuído à população de $\mathrm{T} \mathrm{CD} 4^{+}\left(\mathrm{CD} 44^{\mathrm{hi}}, \mathrm{CD} 25^{+}\right.$, $\mathrm{CD}^{+} 9^{+}, \mathrm{CD}_{62} \mathrm{~L}^{\text {lo }}$ e $\mathrm{CD} 45 \mathrm{RB}^{\text {lo }}$ ) e que a população de linfócitos $\mathrm{T} \mathrm{CD} 8^{+}$ativada encontrava-se em número reduzido nos pulmões. Além disso, foi atribuída à atividade efetora dos linfócitos $\mathrm{T} \mathrm{CD}^{+}$e sua produção elevada de IFN- $\gamma$ à redução da carga fúngica nos pulmões na segunda semana de infecção. Porém, nos órgãos linfóides secundários (linfonodo e baço) os linfócitos T CD4 ${ }^{+}$estavam em número reduzido e os linfócitos $\mathrm{T} \mathrm{CD}{ }^{+}$apresentavam-se em número superior ao das células $\mathrm{T} \mathrm{CD}^{+}$. Além disso, ambas as populações de linfócitos apresentavam elevada capacidade proliferativa e a presença de IFN- $\gamma$ era proveniente de linfócitos T CD8 ${ }^{+}$, o que não foi visto no foco primário da infecção. Assim, foram atribuídos papéis diferentes aos linfócitos em compartimentos distintos durante a resposta imune. As células T, que inicialmente recebem o estímulo antigênico nos órgãos linfóides secundários, passam a proliferar e quando seguem para o foco primário da infecção, adquirem marcadores de ativação e atividade efetora (produção de IFN- $\gamma$ ), quando essas células novamente entram em contato com o antígeno na tentativa de erradicá-lo.

Apesar de a fase crônica da infecção apresentar número semelhante de células T CD8 ${ }^{+}$ nos pulmões de animais KO e WT, essas células talvez poderiam estar em números aumentados no baço de animais $\mathrm{KO}$, já que a disseminação para fígado e baço foi a mesma 
para ambos os grupos ensaiados. Deste modo, a análise do fenótipo de linfócitos esplênicos nos daria informações se há compartimentos celulares diferenciados e com predominância de linfócitos T CD4 ${ }^{+}$ou T CD ${ }^{+}$durante a fase crônica da infecção.

Além de estudarmos o infiltrado linfocitário pulmonar, achamos ser importante a caracterização do número e fenótipo dos macrófagos alveolares nas fases aguda e crônica da infecção. Nos 15 dias de infecção pelo $P$. brasiliensis, os macrófagos pulmonares de animais iNOS KO estavam em números aumentados (CD11b) e apresentavam expressivo aumento das moléculas coestimuladoras CD40, CD80 e CD86 e de moléculas de MHC classe II, ou Iab Assim, a menor carga fúngica nos pulmões de animais $\mathrm{KO}$ estava relacionada com o maior recrutamento de linfócitos $\mathrm{T}_{\mathrm{CD}}{ }^{+}$e $\mathrm{T} \mathrm{CD}^{+}$e concomitante aumento do número de macrófagos pulmonares, que apesar de serem deficientes de óxido nítrico, apresentam-se mais ativados que os de animais iNOS normais. Estas células apresentavam, entretanto, características de boa eficiência quanto à apresentação de antígenos, isto é, grande expressão de moléculas de MHC de classe II e coestimulatórias. Além disso, vimos que apesar de deficientes na produção de óxido nítrico, os macrófagos alveolares desses animais foram os que apresentaram expressiva produção de peróxido de hidrogênio talvez como um mecanismo compensatório na tentativa de erradicar o fungo durante a fase aguda do nosso modelo.

Mamoni et al. (2006) mostraram que pacientes com PCM que tiveram contato com o fungo, mas não progrediram para a doença, eram aqueles que apresentavam maior número de células que expressavam a molécula CD80 e HLA-DR, ou seja MHC classe II. A expressão de CD80 tem sido associada com a resposta imune do perfil Th1 com a ativação de linfócitos T CD8 ${ }^{+}$(MAURI \& PICHLER, 1996) enquanto que a coestimulação por CD86 estaria envolvida com a síntese de IL-4 e consequente resposta do perfil Th2 (RANGER et al., 1996).

Mejri e Gottstein (2006) mostraram o papel da molécula Ia e das moléculas coestimuladoras CD40, CD80, CD86 em macrófagos peritoneais de animais C57BL/6, naïves e infectados por Echinococcus multilocularis com relação à atividade apresentadora de antígeno e de ativação e proliferação de linfócitos T. Foi visto na fase aguda da infecção que os macrófagos infectados apresentavam expressivo aumento da molécula Ia, ou MHC de classe II, indispensável para o primeiro sinal de ativação de linfócitos por interagirem com moléculas do TCR de linfócitos T. Além disso, a neutralização concomitante de CD80 e CD86 em macrófagos naïves reduziu a resposta linfoproliferativa tanto de linfócitos $\mathrm{T}$ virgens, quanto de linfócitos T infectados. Porém, o uso de anti-CD40 em macrófagos naïves aumentou a atividade proliferativa de linfócitos $\mathrm{T}$ virgens e infectados, enquanto que o 
tratamento com anti-CD40 em macrófagos infectados prejudicou a atividade da proliferação linfocitária.

A sequência de sinalização e ativação celular ocorre quando a partir do primeiro sinal, o TCR dos linfócitos e o MHC juntamente com o peptídeo antigênico de células APC, leva à estimulação da expressão de CD40L nos linfócitos, resultando na expressão de CD40 nas APCs (GREWAL et al., 1996). A ativação das APCs mediada por CD40 acaba por aumentar a expressão de moléculas coestimuladoras CD80 e CD86 as quais estimularão os linfócitos T através da interação com o receptor CD28, sendo este o segundo sinal de ativação, e resultará em completa ativação celular (APC e linfócitos) (YANG e WILSON, 1996).

A sinalização celular mediada por CD40 pode resultar na secreção de citocinas por macrófagos, principalmente a IL-12 que permite a maturação de linfócitos $\mathrm{T}$ e desvio para o padrão Th1 de imunidade (KENNEDY et al., 1996).

Assim, na fase aguda do nosso modelo, demonstramos significativo aumento do número de células que expressam MHC de classe II e moléculas coestimulatórias em macrófagos de animais iNOS KO, sugerindo uma melhor apresentação antigênica favorecendo a ativação dos linfócitos $\mathrm{T}$ que são importantes no controle da carga fúngica pulmonar deste período. Consideramos ainda importante o estudo do infiltrado das subpopulações fenotípicas de macrófagos, MØ, e células dendríticas, DC, neste momento da infecção. Sabemos que as DC têm como principal função a apresentação antigênica para os linfócitos $\mathrm{T}$ e posterior polarização da resposta imune celular para Th1 ou Th2; ainda participam, com menor importância, na morte de micro-organismos e produção de citocinas. Os MØ por sua vez são consideramos fundamentais na eliminação do patógeno, com produção de radicais de oxigênio e nitrogênio, além de realizarem mais eficientemente a fagocitose de micro-organismos opsonizados, participam também da formação e manutenção de granulomas e de maneira secundária, mas não menos importante da apresentação antigênica (MANSOUR e LEVITZ, 2002). Observamos que a população de macrófagos, representada por $\mathrm{CD} 11 \mathrm{~b}^{\text {high }} \mathrm{CD} 80^{\text {high }}$, mostrou-se em maior número no infiltrado pulmonar de animais iNOS KO em relação aos animais controle. Já a caracterização do fenótipo para células dendríticas $\mathrm{CD} 11 \mathrm{c}^{\text {high }} \mathrm{CD} 86^{\text {high }}$ mostrou-se em número semelhante nos pulmões para ambos os grupos de animais. Deste modo, pudemos definir que o aumento de populações com características de células apresentadoras de antígenos, APC, nos pulmões eram caracterizadas pela presença de macrófagos que são ainda importantes na eliminação do patógeno.

Na décima semana de infecção, os animais deficientes de NO também apresentaram aumento do número de macrófagos que expressam as moléculas coestimulatórias CD80 e 
CD40, apesar destes animais terem carga fúngica pulmonar maior que a dos animais controle. Ainda pudemos observar que o número de macrófagos pulmonares de animais $\mathrm{KO}$ foi maior que o número dos macrófagos dos animais $\mathrm{KO}$ na fase aguda. Parece que, apesar dos macrófagos desses animais estarem menos ativados na fase crônica, um maior infiltrado celular pôde ser observado na tentativa de conter a carga fúngica nos pulmões nesse momento da doença. Ressaltamos que nessa fase da infecção, observamos a formação de granulomas melhor organizados com intenso infiltrado inflamatório que continha a grande quantidade de fungo no foco primário da infecção. Não podemos também descartar a ação fungicida dos macrófagos ativados através de mecanismos NO-independentes, como aquele mediado pela enzima IDO e a produção de radicais de oxigênio.

Outra abordagem que consideramos ser importante para o estudo dos mecanismos imunológicos operantes em nosso modelo de infecção seria a caracterização da presença de células $\mathrm{T}$ reguladoras (Treg) nos infiltrados inflamatórios de pulmão nos 2 períodos estudados. Essas células apresentam o fenótipo $\mathrm{T} \mathrm{CD} 4{ }^{+} \mathrm{CD} 25^{+}$, expressam de maneira constitutiva o marcador CD25 (cadeia $\alpha$ do receptor de IL-2), CTLA-4 ("cytotoxic T lymphocyte-associated antigen"- inibidor da ativação prolongada de linfócitos T) (BELKAID e ROUSE, 2005), GITR ("glucocorticoid-induced tumor necrosis factor receptor"), ou TNFR (SHEVACH et al., 2002), CD45RO (DIECKMAN et al., 2001), TGFß1 de membrana (NAKAMURA et al., 2004) e o fator de transcrição nuclear Foxp3 ${ }^{+}$(FONTENOT e RUDENSKY, 2005).

As células $\mathrm{T} \mathrm{CD} 4^{+} \mathrm{CD} 25^{+}$expressam seletivamente o fator de transcrição Foxp3 importante para a atividade supressora dessas células (HORI, et al. 2003). Células Treg atuam através da inibição da produção de IL-2 bloqueando o ciclo celular de linfócitos T CD4 ${ }^{+}$e T $\mathrm{CD}^{+}$, além de suprimir a atividade proliferativa de linfócitos $\mathrm{CD}^{+} \mathrm{CD} 25^{-}$(NAKAMURA et al., 2001). Agem também sobre células da imunidade inata, inibindo a sua ação e ativação.

O possível mecanismo da ação supressora das células Treg se dá pelo contato direto célula-célula, envolvendo sinais inibidores de CTLA-4, GITR e TGF- $\beta$ de membrana (READ, et al., 2000; SHIMIZU et al., 2002; NAKAMURA et al., 2001), ou pela provável produção, mas não exclusivamente dessas células, das citocinas anti-inflamatórias IL-10 e TGF- $\beta$ (ASSEMAN et al., 1999). É importante ressaltar que para a manutenção e sobrevivência dessas células é necessária a presença das citocinas TGF- $\beta$ e IL-2.

Nossos estudos indicam na fase inicial da doença um número equivalente de células Treg nos pulmões de ambas as linhagens estudadas. Neste momento da infecção, observamos 
um maior afluxo de linfócitos $\mathrm{T}$ efetores e macrófagos ativados nos pulmões de animais deficientes de NO na tentativa de erradicar o fungo, observado pelo menor número de UFC.

$\mathrm{Na}$ fase crônica, entretanto, foi encontrado aumento do número de células reguladoras nos pulmões de animais KO que poderia ter propiciado o menor número de linfócitos $\mathrm{T}$ efetores ativados, resultando no subsequente aumento da carga fúngica pulmonar nesses animais. Notamos neste momento que os níveis das citocinas anti-inflamatórias IL-10 e TGF$\beta$ pulmonares foram semelhantes para ambos os grupos de animais. Assim, a ausência de NO levou ao aumento de células $\mathrm{T}$ efetoras as quais posteriormente puderam ser controladas pela maior expansão das células T reguladoras; além disso, pode-se inferir uma dupla ação do óxido nítrico que inibe a indução e expansão de ambas as sub-populações de linfócitos T, os efetores e os reguladores. Este mecanismo de controle da resposta imune associado às células Treg não foi previamente descrito na imunossupressão induzida pelo NO na PCM murina e deverá ser considerado como mecanismo regulatório importante mediado pela produção do óxido nítrico.

Ainda na fase crônica do nosso modelo verificamos que a expansão de células Treg foi concomitante com a redução do número de células T CD8 citotóxicas nos pulmões dos animais NO-deficientes. Talvez essas células reguladoras possam ter suprimido a expansão e ação das T CD8 as quais teriam papel importante no controle da carga fúngica nos pulmões neste momento da doença. Corroborando com nossos resultados, em elegante trabalho Haeryfar et al. (2005) mostraram que a depleção de células reguladoras com anticorpo monoclonal anti-CD25 ou PC61, levou à expansão de linfócitos T CD8 citotóxicos com melhor capacidade citotóxica diante de células infectadas pelo vírus influenza A e células tumorais. Essa depleção era dependente de linfócitos T CD4, já que em animais CD4 ${ }^{-/-}$ deficientes a depleção com PC61 não alterou o perfil nem a atividade das células T CD8, mostrando que as células reguladoras eram do fenótipo $\mathrm{T} \mathrm{CD} 4^{+} \mathrm{CD} 25^{+}$.

O possível mecanismo das Treg sobre os linfócitos T CD8 seria pela inibição da divisão celular desses linfócitos citotóxicos. Nossos resultados mostraram níveis semelhantes de IL-10 e TGF- $\beta$ nos pulmões de animais KO, sugerindo que a ação dessas Treg poderia ser por contato direto célula-célula.

Niedbala et al. (2007) demonstraram que o NO induz uma população celular reguladora $\mathrm{T} C D 4^{+} \mathrm{CD} 25^{+} \mathrm{Foxp}^{-}$, chamada de NO-Treg, a qual produz IL-4 mas não TGF- $\beta$ e exerce sua atividade supressora em linfócitos T CD4 ${ }^{+} \mathrm{CD} 25^{-}$dependente de IL-10. A atividade dessas NO-Treg é inibida pela ação do $\mathrm{N}^{\mathrm{G}}$-monometil-L-arginina, um inibidor da síntese de iNOS. 
Muitos trabalhos relatam a importância das células T-reguladoras em casos crônicos de infecção onde, devido à persistência do patógeno, essas células estariam controlando as respostas imunes que poderiam causar quadros inflamatórios exacerbados na tentativa de erradicar o agente infeccioso. Além disso, por impedirem a cura asséptica, as células Treg controlariam a manutenção do patógeno e em consequência, a memória imunológica.

Assim, quadros crônicos de infecção pelo M. tuberculosis (GEROSA et al., 1999), $P$. falciparum (PLEBANSKI et al., 1999), HIV (OSTROWSKI et al., 2001), C. albicans (MONTAGNOLI, 2002), S. mansoni (BAUMGART et al., 2006), L. major (BELKAID e ROUSE, 2005) mostram que a persistência do patógeno está relacionada com a presença de células T reguladoras juntamente com a síntese de citocinas anti-inflamatórias IL-10 e TGF- $\beta$.

Em elegante trabalho, Belkaid et al. (2002) mostraram que na infecção crônica por Leishmania major a presença de Treg, além de suprimir as respostas de linfócitos T CD4 ${ }^{+}$e síntese de IFN- $\gamma$, estava associada à síntese de IL-10 que era importante para a permanência do patógeno. Assim, além de atenuar a produção de citocinas próinflamatórias do perfil Th1, as células Treg ainda interferiam na atividade microbicida de macrófagos. A presença dessas células parece proporcionar um equilíbrio na atividade efetora das células $\mathrm{T} \mathrm{CD}^{+}$que, na tentativa de eliminar o patógeno, poderiam causar danos ao hospedeiro. Recentemente, Cavassani et al. (2006) mostraram na paracoccidioidomicose crônica, forma adulta, que pacientes que apresentavam doença grave, com maior carga fúngica nas biopsias das lesões teciduais, um aumento de células Treg $\mathrm{T} \mathrm{CD} 4^{+} \mathrm{CD} 25^{+} \mathrm{Foxp}^{+}$que produziam altos níveis de TGF- $\beta$. Essas células apresentavam receptores de migração para os tecidos lesados, receptores de "homing", CCR4 e CCR5 (receptores de quimiocinas- CCL22 e CCL5 respectivamente) que as direcionavam para os tecidos onde havia grande quantidade de fungos. Ainda, o estudo in vitro dessas células mostrou, que as células Treg apresentavam grande capacidade de supressão da proliferação celular de leucócitos do sangue periférico desses pacientes. Em concordância com esse resultados, Moreira et al. (2008) mostraram que animais deficientes de CCR5 apresentavam maior controle do crescimento fúngico e menor infiltrado de células Treg Foxp $^{+}$nas lesões, mostrando que este receptor era indispensável pelo maior recrutamento de células Treg Foxp $3^{+}$para o local da infecção onde há persistência do patógeno.

Como na segunda semana de infecção mostramos que a menor carga fúngica nos pulmões de animais deficientes de NO poderia ser atribuída ao aumento de linfócitos T efetores ativados $\mathrm{CD}^{+}$e $\mathrm{CD}^{+}$, além de maior número de macrófagos que expressavam moléculas MHC de classe II e coestimuladoras, e ainda pequena expansão de células T 
reguladoras, obtivemos neste período aumento dos níveis da citocina TNF- $\alpha$ pulmonar. Esta citocina tem expressiva importância na organização de granulomas, já que estimula a expressão de moléculas de adesão ICAM-1 e VCAM-1 no endotélio vascular e nas superfícies de inúmeras células, além de proporcionar o aumento do recrutamento de leucócitos para o foco inflamatório (RESNICK e WELLER, 1993; HAMACHER e SCHABERG, 1994).

Em conjunto, estas informações levaram-nos a perguntar como seria o comportamento da infecção pelo $P$. brasiliensis nos animais iNOS KO (e seu grupo controle iNOS normais), se neutralizássemos essa citocina. Realizamos então experimentos de depleção de TNF- $\alpha$, nos dias 0,6 e 12 pós infecção, baseados na hipótese que o TNF- $\alpha$ desempenharia o papel protetor na fase aguda (redução do número de UFC) e na fase crônica (organização das lesões em granulomas) na infecção de animais iNOS KO.

A depleção de TNF- $\alpha$ levou ao aumento não significativo da carga fúngica em ambos animais KO e WT, com relação aos seus respectivos grupos IgG normal, durante a segunda semana de infecção. Entretanto, a depleção de TNF- $\alpha$ dos animais KO levou os mesmos a apresentar carga fúngica equivalente àquela apresentada pelos animais iNOS normais infectados (controle IgG) o que demonstra que, ao menos parcialmente, o TNF- $\alpha$ é o responsável pela menor carga fúngica pulmonar de animais iNOS KO aos 15 dias de infecção.

Huffnagle et al. (1996) verificaram a importância da citocina TNF- $\alpha$ na infecção pulmonar por Cryptococcus neoformans, neutralizando-a nos primeiros momentos da resposta imune (dias 0, 3, 6 e 9) e com uma única dose de anticorpo anti-TNF- $\alpha$ (dia 0). Assim, verificou-se com o primeiro tratamento, um expressivo aumento da carga fúngica pulmonar e redução na resposta de hipersensibilidade do tipo tardio (HTT), além de diminuição do infiltrado celular de sub-populações celulares (neutrófilos, macrófagos e linfócitos T CD4 ${ }^{+}$) infiltrantes de pulmões.

Os macrófagos alveolares, que inicialmente entram em contato o $C$. neoformans, são a principal fonte de TNF- $\alpha$ pulmonar (HUFFNAGLE et al., 1995). A expressão de RNAm para essa citocina ocorre a partir de 48 horas (HUFFNAGLE et al., 1996) e o pico de sua expressão se estabelece no $7^{\circ}$ dia de infecção (HERRING et al., 2002).

Caracterizamos ainda se neste momento da doença, onde a depleção de TNF- $\alpha$ levou a carga fúngica pulmonar equivalente em animais $\mathrm{KO}$ depletados com relação ao grupo WT controle (tratados com IgG), o perfil de citocinas pró e anti-inflamatórias pulmonares e hepáticas. A neutralização com anticorpo anti-TNF- $\alpha$ levou a redução dos níveis pulmonares da citocina Th1, IFN- $\gamma$ nos animais KO com relação ao grupo WT também depletado. Ainda nos pulmões essa depleção resultou em aumento dos níveis da citocina Th2, TGF- $\beta$ nos 
animais $\mathrm{KO}$ com relação ao grupo KO controle (IgG). As citocinas pulmonares TNF- $\alpha$, IL-12 e IL-10 permaneceram inalteradas com a depleção. No fígado pudemos observar ainda que a depleção resultou também na diminuição dos níveis de IFN- $\gamma$ dos animais $\mathrm{KO}$ com relação aos animais KO controle. As citocinas hepáticas TNF- $\alpha$, IL-12, IL-10 e TGF- $\beta$ permaneceram inalteradas com a depleção. Portanto, verificamos que a neutralização deste importante mediador inflamatório levou a um padrão resposta imune do tipo Th2, com aumento da citocina TGF- $\beta$ pulmonar e redução dos níveis de IFN- $\gamma$ tanto nos pulmões como no fígado. Este perfil de citocinas nos ajuda a entender o papel do TNF- $\alpha$ no nosso modelo de infecção pulmonar em animais NO-deficientes. Mais uma vez, esta importante citocina pode ter sido responsável pela melhor resposta imune e controle da carga fúngica nesses animais deficientes.

Corroborando com nossos resultados, Herring et al. (2002) mostraram que a neutralização de TNF- $\alpha$, no dia 0 da infecção por $C$. neoformans, induziu níveis diminuídos das citocinas do tipo Th1 (IL-12 e IFN- $\gamma$ ) com concomitante aumento das citocinas do tipo Th2 (IL-4 e IL-5), além de expressiva eosinofilia e aumento dos níveis séricos de IgE. Atribuiu-se ao bloqueio de TNF- $\alpha$ uma mudança de polarização do padrão Th1 para o padrão Th2 de imunidade. Além disso, esse tratamento prejudicou o "clearance" fúngico pulmonar uma vez que o número de UFC aumentou a partir do $14^{\circ}$ dia, além de reposta celular deprimida (diminuição de HTT). Ainda no modelo da criptococose, Herring et al. (2005) mostraram que essa neutralização de TNF- $\alpha$ resultou em diminuição dos níveis das quimiocinas MCP-1, MIP-2 e KC, concomitante com o menor infiltrado celular (neutrófilos, macrófagos, linfócitos, e eosinófilos) e de células dendríticas nos linfonodos drenantes dos pulmões de animais infectados.

Em concordância com nossos resultados, no modelo de histoplasmose experimental, Allendoerfer e Deepe (1998) mostraram que a neutralização com anti-TNF- $\alpha$ acarretava em aumento da carga fúngica pulmonar no sétimo dia e sexta semana de infecção, porém, com disseminação para fígado e baço equivalente ao grupo $\operatorname{IgG}$ e ainda, essa depleção levou à mortalidade acentuada dos animais depletados com relação ao grupo controle. A análise das citocinas pulmonares mostrou que essa depleção resultava em expressivo aumento de IL-4, IL-10, GM-CSF, TGF- $\beta$, IL-6 e IL-12 e redução dos níveis de IFN- $\gamma$ no quinto dia de infecção. Assim, um balanço de citocinas tendendo a uma polarização do perfil antiinflamatório Th2, possa ter contribuído para a doença mais grave.

Além do papel atribuído ao TNF- $\alpha$ no recrutamento celular e na indução de IL-12 e IFN- $\gamma$ (HERRING et al., 2002), essa importante citocina próinflamatória também promove a 
maturação e migração de células dendríticas imaturas (imDC) dos tecidos periféricos para os linfonodos drenantes onde ocorre a estimulação e expansão clonal dos linfócitos $\mathrm{T}$ (CUMBERBATCH e KIMBER, 1995; RITTER et al., 2003; MARTIN-FONTECHA et. al., 2003).

Realizamos também a caracterização das UFC na oitava semana de infecção, e não como usualmente na décima, já que os animais iNOS KO depletados de TNF- $\alpha$ não sobreviveram até este período. A depleção da citocina foi realizada até o décimo segundo dia, e depois estudado o número de UFC na oitava semana de infecção onde resultou em pequeno aumento da carga fúngica, tanto para os animais KO como WT com relação aos animais controle. Este aumento, entretanto, não foi significativo quando comparado ao dos animais tratados com IgG normal. Houve disseminação para fígado e baço, sendo, porém semelhante para todos os grupos estudados.

Assim, diferente do esperado, a depleção do TNF- $\alpha$ não levou a considerável aumento da carga fúngica nos pulmões dos animais deficientes de NO, apesar do importante papel protetor dessa citocina na fase aguda do nosso modelo.

Por outro lado, a depleção de TNF- $\alpha$ acarretou na morte precoce da maioria dos animais deficientes de NO, os quais não sobreviveram até a décima semana de infecção quando seriam sacrificados para a análise da gravidade da doença. Do animal sobrevivente $\mathrm{KO}$, foi realizada a análise de UFC, e observou-se intenso crescimento fúngico no fígado e baço, além de grande quantidade de fungos nos pulmões. A análise histopatólogica pulmonar mostrou presença de necrose por todo o parênquima, as lesões apresentavam-se sem a organização em granulomas bem formados havendo, em concomitância, grande quantidade de fungos no tecido, o que poderia ter sido responsável pela disseminação fúngica para o fígado e baço (dados não mostrados). Esta grave infecção teria levado à morte dos animais. Os animais WT, tratados com IgG normal e com anti-TNF- $\alpha$ sobreviveram até a décima semana.

A deficiência de óxido nítrico associada à ausência da citocina próinflamatória TNF- $\alpha$ parecem resultar em efeito deletério não relacionado, entretanto, ao aumento da carga fúngica. Vale lembrar que a depleção de TNF- $\alpha$ elimina a pequena vantagem dos animais iNOS KO em relação à carga fúngica na segunda semana pós-infecção, porém determina intensa mortalidade em períodos mais tardios da infecção já que sem TNF- $\alpha$ os camundongos KO morrem agudamente.

No modelo de infecção por L. major, o papel do TNF- $\alpha$ foi relacionado com a melhor organização das lesões e controle do infiltrado inflamatório, já que animais deficientes desta citocina e dos receptores para a mesma (TNFR1, p55 e TNFR2, p75) mostraram intenso 
infiltrado inflamatório, porém com menor parasitemia, já que níveis elevados de IFN- $\gamma$ e da frequência de linfócitos $\mathrm{T} \mathrm{CD}^{+}$foram vistos nos linfonodos desses animais. Assim, o TNF- $\alpha$ parece ser essencial para a resolução e controle das lesões inflamatórias durante a infecção por L. major, mas não no controle da replicação do parasita (CHAKOUR et al., 2003).

Deste modo, para melhor entendermos o efeito da depleção dessa importante citocina, realizamos o estudo do infiltrado leucocitário nos pulmões de animais KO e WT depletados de TNF- $\alpha$ na segunda semana pós-infecção. De maneira inesperada, a depleção resultou no aumento significante do número de linfócitos $\mathrm{T} \mathrm{CD}^{+}$e $\mathrm{T} \mathrm{CD}^{+}$, de células ativadas expressando $\mathrm{CD} 69^{+}$e $\mathrm{CD} 25^{+}$e ainda, aumento de linfócitos duplo positivos $\left(\mathrm{T} \mathrm{CD}^{+} \mathrm{CD} 69^{+} \mathrm{e}\right.$ $\mathrm{T} \mathrm{CD}^{+} \mathrm{CD}^{+} 9^{+}$) nos pulmões de ambos os grupos, KO e WT, depletados de TNF- $\alpha$, com relação aos seus grupos IgG normal. Além disso, o grupo WT tratado com anti-TNF- $\alpha$ mostrou ainda aumento de linfócitos ativados $\mathrm{T} C D 4^{+} \mathrm{CD} 25^{+}$nos pulmões com relação ao seu grupo controle IgG normal.

Essa depleção também resultou nos camundongos KO e WT em aumento significante do número de macrófagos pulmonares (CD11b e CD11c) os quais apresentavam maior expressão da molécula coestimuladora CD80. Ainda, os animais WT tratados com anti-TNF- $\alpha$ mostraram aumento do número de macrófagos com expressão de $\mathrm{Ia}^{\mathrm{b}}$ e de CD40, comparado ao grupo WT IgG normal. Além disso, ambas as linhagens de animais depletadas apresentaram aumento do número de macrófagos que expressavam dupla marcação: $\mathrm{CD} 11 \mathrm{bCD} 80^{+}$e $\mathrm{CD}_{40} \mathrm{Ia}^{\mathrm{b}}$. O número de macrófagos que expressavam a molécula CD86 foi semelhante para todos os grupos de animais.

Como vimos anteriormente em vários trabalhos aqui citados, o uso de anticorpo antiTNF- $\alpha$ acarretou a redução do infiltrado celular para o foco infeccioso. Nossos experimentos, entretanto, mostraram que essa depleção até o décimo segundo dia, e posterior realização do estudo do infiltrado celular no décimo quinto dia, resultou em expressivo aumento leucocitário tanto nos animais KO como nos animais WT, e esses dados são semelhantes ao de Chakour et al. 2003. Os níveis pulmonares e hepáticos de TNF- $\alpha$ no $15^{\circ}$ dia pós-infecção foram equivalentes aos dos animais não tratados, descartando a possibilidade de um mecanismo rebote dos níveis de TNF- $\alpha$ que poderia ter ocorrido quando a mesma foi neutralizada e depois interrompido o tratamento.

Dados semelhantes aos nossos foram vistos na infecção pelo $H$. capsulatum, onde a depleção de TNF- $\alpha$ resultou inesperadamente em expressivo aumento do número absoluto de linfócitos $\mathrm{T} \mathrm{CD}^{+}$e $\mathrm{T} \mathrm{CD}^{+}$no infiltrado pulmonar dos animais depletados. A análise histopatológica das lesões de pulmão mostrou ainda que apesar do intenso infiltrado 
inflamatório, a neutralização de TNF- $\alpha$ aboliu a organização das lesões em granulomas, ocasionando uma maior carga fúngica pulmonar e consequente menor tempo de sobrevida desses animais, comparado ao grupo controle (ALLENDOERFER e DEEPE, 1998).

Então, nossos resultados mostraram que os camundongos NO-deficientes e depletados de TNF- $\alpha$ apresentaram além de relativo aumento da carga fúngica nos pulmões na fase aguda, um desvio do padrão de citocinas para o perfil Th2 e intenso infiltrado inflamatório de linfócitos T CD4, T CD8 e macrófagos ativados para o sítio primário da infecção. Além disso, em momentos mais tardios da doença, pudemos verificar que esses animais morreram precocemente devido a uma intensa resposta inflamatória nos pulmões.

Além do óxido nítrico ser importante molécula microbicida na eliminação de inúmeros patógenos, sabe-se também da sua importância na indução de apoptose celular durante a eliminação do patógeno e consequente homeostase do sistema imune, ou seja, este mediador funciona como "feedback" negativo no controle da ativação exacerbada da resposta imune (WU-HSIEH et al., 1998; DALTON et al., 2000). Vários trabalhos mostraram que níveis elevados de NO produzidos por macrófagos infectados e ativados por IFN- $\gamma$ levam ao aumento da expressão de Fas na sua superfície, e sendo este importante receptor para apoptose celular, liga-se ao FasL presente em linfócitos T CD4 levando à apoptose desses macrófagos (ALBINA, et al., 1993; RAMSDELL et al., 1994; CONCEIÇÃO-SILVA, et al., 1998; NIINOBU et al., 2000).

Deste modo, o NO ao mesmo tempo induz atividade microbicida de macrófagos e regula o número dessas células através da interação com o FasL dos linfócitos T CD4+.

Como nossos animais são deficientes de NO, vimos um intenso infiltrado inflamatório que inicialmente poderia conter o foco infeccioso, mas devido a ativação exacerbada do sistema imune e talvez pela deficiência de apoptose celular, levou ao quadro mais grave da doença em momentos mais tardios. Ainda com a depleção de TNF- $\alpha$ vimos que esses animais mostraram intensa inflamação nos pulmões. O receptor FasL é também conhecido como receptor da família do TNF, e quando depletamos esta citocina poderia também ter, de algum modo, afetado esses receptores FasL, reduzindo assim os níveis de apoptose celular resultando em intensa atividade inflamatória e ativação acentuada do sistema imune na fase aguda do nosso modelo. Através da marcação de células positivas para Anexina V, um marcador de apoptose precoce, verificamos na segunda semana de infecção que os animais NO-deficientes apresentaram maior frequência de células apoptóticas em relação às células dos animais WT. Por outro lado, a depleção de TNF- $\alpha$ reduziu a frequência de células apoptóticas nos pulmões dos animais iNO KO comparado às células do grupo WT também 
depletado. Pudemos sugerir que devido ao intenso infiltrado inflamatório nos pulmões dos animais NO-deficientes, poderia resultar em consequente aumento do número de células apoptóticas na tentativa de conter a ativação exacerbada do sistema imune. Com a depleção de TNF- $\alpha$, observamos um intenso recrutamento celular para os pulmões nos animais iNOS KO e consequente menor número de células apoptóticas nestes animais em relação ao grupo WT depletado (dados não mostrados).Como nós realizamos este experimento somente uma vez resolvemos não apresentá-lo nos resultados.

Em elegante trabalho Chakour et al. (2003) mostraram no modelo de infecção por $L$. major que animais deficientes de FasL $(g d l)$ e duplo KO para FasL e TNF- $\alpha\left(g d l \mathrm{TNF}^{-/-}\right)$ apresentaram maior parasitemia na sexta semana de infecção, além de aumento da frequência de linfócitos T CD4 nos linfonodos, concomitante aos níveis aumentados de IFN- $\gamma$ e maior infiltrado inflamatório nas lesões. Além disso, os macrófagos desses animais produziam níveis normais de NO o que não afetou na diminuição da carga parasitária. A adição de FasL recombinante juntamente com IFN- $\gamma$ na cultura de macrófagos infectados mostrou expressiva redução da parasitemia. Assim, atribui-se a importância ao FasL ao controle da replicação do parasita, e posterior apoptose dos macrófagos exacerbadamente ativados.

Na histoplasmose experimental, Wu-Hsieh et al. (1998) demostraram que esplenócitos de camundongos infectados morriam mais rapidamente por apoptose do que os esplenócitos de animais não infectados. A população apoptótica era constituída por linfócitos T, B e macrófagos e de maneira interessante, a quantidade de núcleos apoptóticos dessas células coincidia com a cinética da expressão de mRNA para iNOS e, conseqüentemente aos níveis de óxido nítrico.

Consideramos importante a análise histopatológica dos pulmões de animais KO e WT depletados de TNF- $\alpha$, na oitava semana de infecção, já que essa citocina possui um papel primordial na formação da organização de lesões em granulomas (BERNARDINO et al., 2009 em revisão; HUFFNAGLE et al., 1996; FLYNN et al., 1995; SOUTO et al., 2000).

O maior infiltrado leucocitário observado nos animais iNOS KO na fase crônica, comparado ao grupo controle, e níveis elevados de TNF- $\alpha$ pulmonar na fase aguda da infecção, resultaram em lesões organizadas em granulomas bem formados e coalescentes que pareciam conter a carga fúngica nos pulmões. Mais ainda, a formação de granulomas nesses animais parece ter sido capaz de conter a disseminação fúngica para outros órgãos, já que não observamos diferenças no número de UFC de fígado e baço entre os animais KO e WT. Além disso, os animais KO e WT apresentaram sobrevida equivalente, o que enfatiza a 
possibilidade de os animais deficientes de óxido nítrico terem se protegido através da melhor organização das lesões pulmonares.

Em concordância com nossos resultados, Bocca et al. (1998) mostraram que a inibição da síntese de NO, com o Nitro-Arg, apesar de induzir carga fúngica pulmonar elevada na oitava semana de infecção, ocasionava lesões pulmonares reduzidas e bem organizadas em granulomas compactos que continham o fungo no foco primário da infecção. Foi visto também níveis elevados de TNF- $\alpha$ do sobrenadante da cultura de macrófagos broncoalveolares dos animais tratados com inibidor de NO.

Quando neutralizamos o TNF- $\alpha$ in vivo nos animais $\mathrm{KO}$, verificamos que as lesões apresentavam-se espalhadas por todo o parênquima pulmonar acompanhada de intensa carga fúngica, e ausência da formação de granulomas. Assim, a secreção de TNF- $\alpha$, poderia, ao menos parcialmente, conferir certa proteção associada com a deficiência de NO.

Souto et al. (2000) demonstraram o papel imunoprotetor atribuído ao TNF- $\alpha$ em animais deficientes para o receptor p55 de TNF- $\alpha$ (p55KO). Estes animais, infectados pelo $P$. brasiliensis, apresentaram no primeiro mês pós-infecção, lesões difusas por todo o parênquima pulmonar, com a presença de poucas células epitelióides e células gigantes multinucleadas em associação com abundante quantidade de leveduras e ausência de formação de granulomas. Além disso, nos animais p55KO, em relação ao grupo controle, verificou-se expressiva carga fúngica pulmonar, disseminação para fígado e baço provavelmente devido à ausência de lesões organizadas sob a forma de granulomas.

Guler et al. (2005) estudaram os efeitos da neutralização total e parcial do TNF- $\alpha$ pelo receptor solúvel de TNF (sTNFR 1) presente no soro de camundongos transgênicos para este receptor e infectados pelo $M$. bovis. Nos animais que apresentaram altos níveis séricos de sTNFR 1 (30-110 $\mu \mathrm{g} / \mathrm{mL})$ ocorria elevada carga bacteriana nos pulmões, fígado e baço, e deficiência na formação de granulomas hepáticos que apresentavam pequeno infiltrado celular e reduzida ativação de macrófagos (pela baixa expressão da iNOS e da enzima fosfatase ácida) além de níveis diminuídos de IL-12 e IFN- $\gamma$ na fase aguda da infecção. Os animais com baixos níveis séricos de sTNFR $1(0,1-1 \mu \mathrm{g} / \mathrm{mL})$, ao contrário, controlaram a carga bacteriana, apresentaram maior sobrevida associada à formação de granulomas com grande infiltrado celular e ativação eficiente de macrófagos.

Em recente trabalho, Plessner et al. (2007) demonstraram no modelo murino de $M$. tuberculosis que a neutralização de TNF- $\alpha$ utilizando um anticorpo anti-TNF- $\alpha$, afetava o comportamento da fase crônica da doença. Assim, a partir de 4 semanas de infecção, o tratamento com anti-TNF- $\alpha$ reduziu a sobrevida dos animais, aumentou a carga bacteriana nos 
pulmões e a análise histopatológica pulmonar mostrou ausência na formação de granulomas. Esses achados são consistentes com a literatura que demonstra que pacientes de variadas patologias autoimunes tratados por anticorpo anti-TNF- $\alpha$ desenvolvem graves quadros de tuberculose (KEANE et al., 2001).

Assim, sendo o TNF- $\alpha$ importante mediador das muitas vias das respostas imunes, incluindo ativação de macrófagos, formação e manutenção de granulomas, regulação da síntese de citocinas e quimiocinas, ativação de células dendríticas (CO et al., 2004; TUFARIELLO et al., 2003), nossos resultados, juntamente com os achados da literatura, mostram que a neutralização do TNF- $\alpha$, mesmo nos primeiros momentos da infecção, pode afetar vias importantes do sistema imunológico em fases distintas de um quadro infeccioso.

Nossos resultados mostraram que a depleção de TNF- $\alpha$, nos animais iNOS KO, resultou em mortalidade precoce, foi responsável pela desorganização das lesões pulmonares e, ainda, resultou em aumento expressivo do infiltrado celular nos pulmões, e polarização de citocinas pulmonares para um perfil com tendência Th2/Th3, sem, entretanto, apresentar aumento da carga fúngica pulmonar. Nossos dados sugerem que o intenso infiltrado inflamatório pulmonar dos animais $\mathrm{KO}$, possa ter contribuído com mortalidade precoce desses animais. O processo inflamatório em si pode resultar em proteção ao hospedeiro, pois pode contribuir com o controle da carga do patógeno tanto nos mecanismos de imunidade inata como adaptativa. A inflamação, entretanto, deve ser controlada por mecanismos antiinflamatórios, mediados por fatores solúveis como celulares, para que não exerça atividade lesiva e deletéria aos tecidos. Nos nossos estudos de depleção de TNF- $\alpha$ ocorreu, inesperadamente, um imenso afluxo de células inflamatórias para o pulmão, o que sugere um processo não controlado e que resultou em morte precoce dos animais KO.

Em recente trabalho, Beisiegel et al. (2009) mostraram que animais deficientes de óxido nítrico e infectados pela cepa virulenta do M. tuberculosis apresentavam intenso infiltrado inflamatório pulmonar, composto predominantemente de PMN acompanhado de altos níveis de mieloperoxidase juntamente com níveis elevados das quimiocinas MIP-2, KC, IL-1 e G-CSF específicas para o recrutamento dessas células. As lesões pulmonares apresentavam-se organizadas em granulomas com porção necrótica central e PMN em apoptose. Deste modo, o excesso da ativação e recrutamento exacerbado de células inflamatórias para os pulmões resultou em lesão tecidual e consequente controle ineficiente da replicação do $M$. tuberculosis nos animais NO-deficientes.

Vimos até o momento, na fase aguda do nosso modelo, que a doença menos grave nos animais iNOS KO, apesar da deficiência na atividade fungicida dos macrófagos alveolares 
desses animais, estava relacionada com maior afluxo celular de linfócitos e macrófagos ativados e ainda níveis elevados de TNF- $\alpha$ pulmonar. Na fase crônica, por outro lado, observamos reversão deste quadro nos animais $\mathrm{KO}$, com maior carga fúngica nos pulmões, apesar das lesões estarem organizadas em granulomas e menor ativação de linfócitos e macrófagos, comparado à fase aguda. Observamos ainda na segunda semana de infecção, aumento de linfócitos $\mathrm{T} \mathrm{CD}^{+}$nos pulmões dos animais deficientes de $\mathrm{NO}$, porém o mesmo não foi observado nestes animais na fase crônica. Então, sabendo da importância dos linfócitos $\mathrm{T} \mathrm{CD}^{+}$no controle da carga fúngica pulmonar e disseminação para outros órgãos, nos animais resistentes e suscetíveis ao P. brasiliensis (CANO et al., 2000; CHIARELLA et al., 2007), propusemos o estudo da depleção destes linfócitos na fase aguda do nosso modelo, quando os mesmos estão em números aumentados nos pulmões de animais KO.

Observamos que a depleção dessa importante sub-população linfocitária aboliu a diferença de carga fúngica nos pulmões, antes observada entre os animais KO e WT, sendo que os animais KO depletados apresentaram número de UFC pulmonar semelhante aos animais WT não depletados. Essa depleção, portanto, elevou a carga fúngica nos pulmões de animais deficientes de NO, mostrando mais uma vez a importância destes linfócitos no controle da carga fúngica pulmonar. A disseminação para fígado e baço foi semelhante para todos os grupos estudados (dados não mostrados).

Ainda, a depleção desses linfócitos $\mathrm{T}_{\mathrm{CD}}{ }^{+}$reduziu expressivamente o número dos mesmos nos pulmões de animais KO e WT, e foi também reduzido o número de linfócitos $\mathrm{T}$ $\mathrm{CD}^{+}$ativados $\left(\mathrm{T} \mathrm{CD}^{+} \mathrm{CD}^{+} 9^{+}\right)$com relação aos grupos, $\mathrm{KO}$ e WT, não depletados. De maneira interessante, essa depleção reduziu significantemente o número de linfócitos T CD4 ${ }^{+}$ e de células ativadas $\mathrm{CD} 9^{+}$e $\mathrm{CD}_{2} 5^{+}$nos pulmões somente dos animais iNOS KO. Os animais WT, depletados ou não, mostraram números de linfócitos T $\mathrm{CD}^{+}$equivalentes. A população celular duplo positiva $\mathrm{T} \mathrm{CD}^{+} \mathrm{CD} 9^{+}$também se encontrou reduzida nos pulmões dos animais KO depletados, comparado aos animais KO IgG. O mesmo comportamento foi visto com o número de macrófagos que foi significantemente reduzido nos pulmões dos animais KO depletados. Um menor número desses macrófagos expressavam as moléculas $\left(\mathrm{CD} 11 \mathrm{~b}, \mathrm{CD} 11 \mathrm{c}\right.$ e $\left.\mathrm{Ia}^{\mathrm{b}}\right)$ e as moléculas coestimuladoras $\left(\mathrm{CD} 40^{+}, \mathrm{CD}^{+} 0^{+}\right.$e $\left.\mathrm{CD}^{+} 6^{+}\right)$e ainda houve redução de células duplo positivas $\left(\mathrm{CD} 11 \mathrm{bCD} 80^{+}, \mathrm{CD} 40^{+} \mathrm{Ia}^{\mathrm{b}}\right.$ e $\left.\mathrm{CD} 11 \mathrm{cCD} 86^{+}\right)$. O número e a ativação dos macrófagos de animais WT depletados, mais uma vez, apresentou-se semelhante comparado aos macrófagos do grupo WT IgG. Como pudemos observar, ocorreu um maior recrutamento e ativação de linfócitos e macrófagos associado ao controle da carga fúngica nos pulmões de animais KO na segunda semana de infecção e que os linfócitos T 
$\mathrm{CD}^{+}$desempenham papel importante no controle da carga fúngica. Além disso, a depleção desses linfócitos levou à redução do recrutamento celular somente nos pulmões dos animais iNOS KO, o que pode ter sido responsável pelo maior número de UFC pulmonar desses animais. Já nos animais WT, como esses linfócitos $\mathrm{T} \mathrm{CD}^{+}$já encontravam-se em números reduzidos nos pulmões, sua depleção não acarretou em redução no infiltrado celular para esses animais e nem aumentou a carga fúngica pulmonar.

Uma hipótese para entendermos o efeito da depleção de linfócitos T CD8 na redução do número de células $\mathrm{T} \mathrm{CD}^{+}$e de macrófagos pulmonares, aliado ao aumento da carga fúngica nos pulmões dos animais NO-deficientes, seria o possível efeito dessa depleção em um grupo especial de células dendríticas do fenótipo CD8 $\alpha^{+}$, as DC linfóides. Essas células estão localizadas na região da polpa branca do baço, mais precisamente na bainha linfóide periarteriolar (PULENDRAN et al., 1997), região esta rica em linfócitos T, favorecendo a interação das DCs com os linfócitos. Essas células $\mathrm{CD} 8 \alpha^{+} \mathrm{DC}$, quando estimuladas por antígeno e/ou IFN- $\gamma$, produzem IL-12 e induzem resposta imune celular do tipo Th1 (HOCHREIN et al., 2001). São ainda altamente endocíticas e possuem a capacidade de internalizar células apoptóticas (IYODA et al., 2002; SCHULZ e SOUSA, 2002) e apresentação antigênica via MHC de classe I (DEN HAAN et al., 2000) para a estimulação de linfócitos T CD8 ${ }^{+}$(JUNG et al., 2002). Essas DCs também podem suprimir as respostas de linfócitos T gerando tolerância (ALBERT et al., 2001; BELZ et al., 2002). Embora as $\mathrm{CD} 8 \alpha^{+} \mathrm{DCs}$ participam na ativação de linfócitos T no reconhecimento de antígenos estranhos (MALDONADO-LOPEZ et al., 1999), essas células dendríticas possuem ainda a capacidade de discriminar antígenos próprios, evitando o desenvolvimento de respostas imune potencialmente autorreativas. Deste modo essas DCs através da ação da IDO (degradação do triptofano em kirunenina) geram apoptose e/ou anergia de linfócitos T, contribuindo assim para a tolerância de linfócitos $\mathrm{T}$ a antígenos próprios na prevenção de doenças autoimunes (GROHMANN, et al., 2000; QUARATINO et al., 2000; DRAKESMITH et al., 2000; GROHMANN et al., 2001).

Assim, sendo as DCs importantes células apresentadoras de antígenos para a estimulação e ativação de linfócitos T, consequentemente as células $\mathrm{T}$ ativadas produziriam IFN- $\gamma$ para a melhor ativação dos macrófagos na eliminação do fungo. Embora nosso trabalho não tenha avaliado a presença das células $\mathrm{CD} 8 \alpha^{+} \mathrm{DC}$ achamos que o tratamento com anticorpo anti-CD8 $\alpha$ possa ter eliminado tanto as células $\mathrm{T} \mathrm{CD} 8^{+}$como as $\mathrm{CD} 8 \alpha^{+} \mathrm{DC}$. Além disso, com um menor número dessas DCs resultaria na diminuição da ativação de linfócitos T CD4 ${ }^{+}$que realmente encontravam-se em número reduzido no infiltrado pulmonar dos animais $\mathrm{KO}$ 
depletados. Ainda, como os linfócitos T CD8 são importante fonte da síntese de IFN- $\gamma$, a redução dos mesmos poderia também ter contribuído para a diminuição do número e ativação dos linfócitos $\mathrm{T} \mathrm{CD}^{+}$do tipo 1 e do afluxo de macrófagos para os pulmões dos animais iNOS-deficientes. A polarização da resposta imune para o perfil Th1 induzido por células dendríticas do fenótipo $\mathrm{CD} 8 \alpha^{+}$foi visto por Hammad et al. (2004) no modelo de asma experimental quando essas CD $8 \alpha^{+} \mathrm{DC}$ esplênicas, primadas com OVA (ovalbumina) e injetadas intratraquealmente em animais trangênicos para OVA, produziam baixos níveis de citocinas do tipo Th2 (IL4, IL-5, IL-10) e altos níveis de IFN- $\gamma$, acompanhado de pouco recrutamento de eosinófilos para os pulmões.

Recentemente, Neuenhahn et al. (2006) mostraram em elegante modelo de infecção pela bactéria intracelular L. monocytogenes que quando os camundongos eram infectados pela via intravenosa, essa bactéria era capturada rapidamente no baço e preferencialmente por células dentríticas do perfil $\mathrm{CD} 8 \alpha^{+} \mathrm{DC}$, já que o número de bactérias recuperadas de outras populações celulares como $\mathrm{M} \emptyset, \mathrm{PMN}$ e $\mathrm{CD} 8 \alpha^{-} \mathrm{DC}$ foi expressivamente inferior ao número recuperado das $\mathrm{CD} 8 \alpha^{+} \mathrm{DC}$, mostrando que essa população especial de células dentríticas são as responsáveis pela captura de bactérias vindas do sangue periférico quando atingem o baço. Observou-se que a depleção de células $\mathrm{CD} 11 \mathrm{c}^{+}$afetou as $\mathrm{CD} 8 \alpha^{+} \mathrm{DC}$ esplênicas assim como o número de bactérias recuperadas. Além disso, esse estudo mostrou que as $\mathrm{CD} 8 \alpha^{+} \mathrm{DC}$, como acreditava-se anteriormente, não estavam restritas somente na região da polpa branca do baço, ou seja, região de linfócitos $\mathrm{T}$, já que essas células foram eficientes na captura de outros tipos de bactérias, como S. typhimurium vindas do sangue além de partículas inertes e células apoptóticas. Deste modo, a presença dessas DCs foi observada também na zona marginal e região da polpa vermelha do baço. Quando este grupo de pesquisadores foi avaliar a capacidade de APCs dessas CD $8 \alpha^{+}$DC na proliferação celular de linfócitos T CD8 ${ }^{+}$, observouse que esses linfócitos proliferavam na presença e, surpreendentemente na ausência dessas DCs, atribuindo neste momento aos M $\varnothing$ a função de APCs na ausência das CD8 $\alpha^{+}$DC.

Sabemos que no modelo de infecção pulmonar pelo $P$. brasiliensis, esse fungo tem a capacidade de disseminar pelo sangue e linfa atingindo fígado e baço. Nossos resultados mostraram que em tempos distintos da doença, fases aguda ou crônica, a disseminação hepática e esplênica é a mesma em ambos animais KO e WT. Ainda no animal que desenvolve maior carga fúngica nos pulmões, essa disseminação permanece equivalente ao grupo menos doente. Não avaliamos a presença dessas CD8 $\alpha^{+} \mathrm{DC}$ esplênicas nos animais NOdeficientes e no seu grupo controle, mas através da literatura, podemos supor que estas DCs tenham um papel relevante na PCM. 
É interessante também supor que as células dendríticas $\mathrm{CD} 8 \alpha^{+}$que produziam IDO estariam controlando a carga fúngica na segunda semana de infecção nos animais deficientes de NO.

A diminuição de células $\mathrm{T} \mathrm{CD}^{+}$e $\mathrm{T} \mathrm{CD}^{+}$, possivelmente induzida pela ausência de apresentação de antígenos do fungo pelas $\mathrm{CD} 8 \alpha^{+} \mathrm{DCs}$, explicariam também o menor afluxo de macrófagos ativados para os pulmões dos animais KO depletados de células CD8 $\alpha^{+}$. Haveria reações de imunidade celular menos intensas no sítio da infecção e o concomitante menor afluxo de monócitos, que se transformariam em macrófagos ativados, para a lesão inflamatória.

Em conclusão, nosso trabalho trouxe até aqui novas informações do papel da síntese de NO na PCM experimental. Primeiro, o papel deste mediador não havia sido previamente investigado no modelo pulmonar de infecção pelo P. brasiliensis usando animais iNOS KO. Segundo, a caracterização do exudato inflamatório de animais deficientes revelou a associação de aumento de células $\mathrm{T}_{\mathrm{CD}} 4^{+}$e $\mathrm{CD}^{+}$ativadas, bem como de macrófagos ativados com menor crescimento fúngico. Essa imunoproteção transitória parece ter sido prejudicada em fases mais tardias da infecção pelo aumento da expansão de células $\mathrm{T}$ reguladoras as quais estavam associadas à presença diminuída de células $\mathrm{T}$ efetoras e de macrófagos ativados nos exudatos pulmonares. Ainda, a proteção resultante da deficiência de NO foi concomitante com aumento da secreção de TNF- $\alpha$ que melhor organizou as lesões pulmonares. Mais ainda, pudemos demonstrar a participação efetiva do TNF- $\alpha$ e de linfócitos $\mathrm{T} \mathrm{CD}^{+}$na resposta imune de animais iNOS KO e WT. A neutralização in vivo de TNF- $\alpha$ e de linfócitos $\mathrm{T} \mathrm{CD}^{+}$aboliu a vantagem transitória conferida pela deficiência de NO na imunidade contra a infecção pelo $P$. brasiliensis. 


\section{CONSIDERAÇÕES FINAIS}

O presente trabalho mostrou o efeito temporal do óxido nítrico em momentos distintos da infecção pulmonar pelo $P$. brasiliensis em animais geneticamente deficientes da enzima óxido nítrico sintase-induzida (iNOS). Sendo o NO importante molécula microbicida importante na eliminação de inúmeros patógenos, mostramos que a sua presença é dispensável na fase aguda do nosso modelo experimental. Os animais NO-deficientes apresentaram doença menos grave com menor número de UFC pulmonar, além de intenso infiltrado inflamatório pulmonar de linfócitos T e macrófagos ativados, que parecem controlar o crescimento fúngico e disseminação do mesmo para órgãos mais distantes. Ainda nesse momento observamos a produção aumentada de TNF- $\alpha$ pulmonar que poderia estar atuando no recrutamento de células e expressão de moléculas de adesão para o foco da infecção. Uma vez neutralizada essa citocina, notamos certo aumento da carga fúngica nos pulmões, uma certa polarização de citocinas para o perfil Th2/Th3 e ainda intenso afluxo inflamatório pulmonar. Verificamos ainda que a presença de linfócitos $\mathrm{T} \mathrm{CD}^{+}$nos pulmões contribuiu com o "clearance" fúngico, já que a depleção desses linfócitos ocasionou em aumento da carga fúngica pulmonar e expressiva redução de migração de células $\mathrm{T}$ e macrófagos para os pulmões dos animais iNOS KO. O estudo da atividade fungicida de macrófagos alveolares mostrou que apesar do menor número de fungos recuperados, esses macrófagos apresentavam atividade fungicida ineficiente, além de não serem ativáveis por IFN- $\gamma$. Além disso, a deficiência de NO resultou no aumento significativo de peróxido de hidrogênio produzido por esses macrófagos, talvez um mecanismo compensatório na tentativa de eliminar o fungo.

Por outro lado, na fase crônica do nosso modelo, observamos quadro da doença contrário àquele da fase aguda. Nos animais iNOS KO pudemos observar aumento da carga fúngica pulmonar, acompanhada de menor ativação de células $\mathrm{T}$ e macrófagos. Neste momento notamos um aumento da frequência de células $\mathrm{T}$ reguladoras que poderiam estar controlando a ativação exacerbada do sistema imune durante a persistência do patógeno. Apesar de maior carga fúngica nos pulmões, as lesões pulmonares mostraram-se organizadas em granulomas bem formados e coalescentes, com intenso infiltrado celular que foi importante para conter o fungo no sítio primário da infecção. Atribuímos este perfil histológico à ação do TNF- $\alpha$, já que a sua neutralização em fases precoces da infecção resultou em desorganização das lesões pulmonares e morte precoce dos animais KO. Ainda, a 
neutralização de TNF- $\alpha$ induziu uma inflamação intensa nos pulmões dos animais iNOS KO, que pode ter contribuído com a menor sobrevida desses animais.

Deste modo, pudemos através de um único modelo experimental, demonstrar que o óxido nítrico controla múltiplas funções imunológicas durante o curso da doença. Além do controle da carga fúngica, regula a reatividade de macrófagos, linfócitos $\mathrm{T}$, síntese de citocinas e organização de lesões inflamatórias. Este conjunto de atividades pode traduzir-se, então, em efeitos deletérios ou protetores aos hospedeiros infectados pelo P. brasiliensis. 


\section{REFERÊNCIAS BIBLIOGRÁFICAS ${ }^{*}$}

ALBERT, M.L.; JEGATHESAN, M.; DARNELL, R.B. Dendritic cells maturation is required for the cross-tolerization of CD8(+) T cells. Nat. Immunol., v. 2, p. 1010-1017, 2001.

ALBINA, J.E.; CUI, S.; MATEO, R.B.; REICHNER, J.S. Nitric oxide-mediated apoptosis in murine peritoneal macrophages. J. Immunol., v., 150, p. 5080-5085, 1993.

ALLENDOERFER, R.; DEEPE, G.S.J. Blockade of endogenous TNF- $\alpha$ exacerbates primary and secondary pulmonary histoplasmosis by differential mechanisms. $\mathbf{J}$. Immunol., v. 160, p. 6072-6082, 1998.

ALLENDOERFER, R.; DEEPE, G.S. Regulation of infection with Histoplasma capsulatum by TNFR1 and 2. J. Immunol., v. 165, p. 2657-2664, 2000.

AKIRA S.; UEMATSU, S.; TAKEUCHI, O. Pathogen recognition an innate immunity. Cell, v. 124, p. 783-801, 2006.

ALMEIDA, O.P.; JUNIOR, J.J. Paracoccidioidomycosis of the mouth: na emerging deep mycosis. Crit. Rev. Oral Biol. Med., v. 14, p. 268-274, 2003.

AL-RAMADI, B.K.; CHEN, Y.W.; MEISLLER, J.J.; EISENSTEIN, T.K. Immunossuppression induced by attenuated Salmonella: Reversal by IL-4. J. Immunol., v. 147, p. 1954-1961, 1991.

ANGULO-ORTEGA, A. Calcifications in paracoccidioidomycosis: are they morphological manifestation of subclinal infections? PAHO Cient. Publ., v. 254, p.129133, 1972.

ARANGO, M.; YARZABAL, L. T-cell dysfunction and hyperimmunoglobulinemia E in paracoccidioidomycosis. Mycophatologia, v. 79, p. 115-123, 1982.

ARISTIZABAL, B.H.; CLEMONS, K.V.; STEVENS, D.A.; RESTREPO, A. Morphological transition of Paracoccidioides brasiliensis conidia to yeasts cells: in vivo inhibition in females. Infect. Immun., v. 66, p. 5587-5591, 1998.

\footnotetext{
* De acordo com:

ASSOCIAÇÃO BRASILEIRA DE NORMAS TÉCNICAS. NBR 6023: Informação e documentação: referências: elaboração. Rio de Janeiro, 2002.
} 
ARRUDA, C.; FRANCO, M.F.; KASHINO, S.; NASCIMENTO, F.R.F.; FAZIOLI, R.A.; VAZ, C.A.C.; RUSSO, M.; CALICH, V.L.G. Interleukin-12 protects mice against disseminated infection caused by Paracoccidioides brasiliensis but enhances pulmonary inflammation. Clin. Immunol., v. 103, p 185-195, 2002.

ARRUDA, C.; FERREIRA, R.C.V.; PINA, A.; KASHINO, S.S.; FAZIOLI, R.A.; VAZ, C.A.C.; FRANCO, M.F.; KELLER, A.C.; CALICH, V.L.G. Dual role of interleukin-4 (IL-4) in pulmonary paracoccidioidomycosis: endogenous IL-4 can induce protection or exacerbation of disease depending on the host genetic pattern. Infect. Immun., v. 72, p. 3932-3940, 2004.

ASSEMAN, C.; MAUZE, S.; LEACH, M.W. An essential role for interleukin 10 in the function of regulatory T cells that inhibit intestinal inflammation. J. Exp. Med., v. 190, p. 995-1004, 1999.

BAIDA, H.; BISELLI, P.J.; JUVENALE, M.; DEL NEGRO, G.M.B.; MENDESGIANNINI, M.J.S.; DUARTE, A.J.S.; BENARD. G. Differential antibody isotype expression to the major Paracoccidioides brasiliensis antigen in juvenile and adult form paracoccidioidomycosis. Microbes Infect., v. 1, p. 273-278, 1999.

BARBER, D.L.; WHERRY, E.J.; AHMED, R. Cutting edge: rapid in vivo killing by memory CD8 T cells. J. Immunol., v. 171, p. 27-31, 2003.

BAUMGART, M.; TOMPKINS, F; LENG J; HESSE, M: Naturally occurring $\mathrm{CD}^{+}{ }^{+} \mathrm{Foxp}^{+}$regulatory $\mathrm{T}$ cells are an essential, IL-10-independent part of the immunoregulatory network in Schistosoma mansoni egg-induced inflammation. $\mathbf{J}$. Immunol., v. 176, p. 5374-5387, 2006.

BEISIEGEL, M.; KURSAR, M.; KOCH, M.; LODDENKEMPER, C.; KUHLMANN, S.; ZEDLER, U.; STÄBER, M.; HURWITZ, R.; KAUFMANN, S.H.E. Combination of host susceptibility and virulence of Mycobacterium tuberculosis determines dual role of nitric oxide in the protection and control of inflammation. J. Infect. Dis., v. 199, p. 1222-1232, 2009.

BELKAID, Y.; PICCIRILLO, C.A.; MENDEZ, S.; SHEVACH, E.M.; SACKS, D.L. Nature, v. 420, p. 502-507, 2002.

BELKAID, Y.; ROUSE, B.T. Natural regulatory $\mathrm{T}$ cells in infectious disease Nat. Immunol., v. 06, p. 353-360, 2005. 
BELZ, G.T.; BEHRENS, G.M.N.; SMITH, C.M.; MILLER, J.; JONES, C.; LEJON, K.; FATHMAN, C.G.; MUELLER, S.N.; SHORTMAN, K.; CARBONE, F.R.; HEATH, W.R. The CD $8 \alpha(+)$ dendritic cells is responsible for inducing peripheral self-toleranceto tissue-associated antigens. J. Exp. Med., v. 196, p. 1099-1104, 2002.

BENARD, G.; ORII, N.M.; MARQUES, H.H.S.; MENDONÇA, M.; AQUINO, M.Z.; CAMPEAS, A.; DEL NEGRO, G.M.B.; DURANDY, A.; DUARTE, A.J.S. Severe juvenile paracoccidioidomycosis in children. Pediatr. Infect. Dis. J., v.13, p.510-515, 1994.

BENARD, G.; MENDES-GIANNINI, M,J.; JUVENALE, M.; MIRANDA, E.T.; DUARTE, A.J.S. Immunosupression in paracoccidioidomycosis: $T$ cell hyporesponsiveness to two Paracoccidioides brasiliensis glycoproteins that elicit strong humoral imune response. J. Infect. Dis. v. 175, p. 1263-1267, 1997.

BERLINER, M.D.; RECA, M.E.Vital staining of Histoplasma capsulatum with Janus Green B. Sabouradia, v. 5, p. 26-29, 1966.

BLOTTA, M.H; MAMONI, R.L.; OLIVIEIRA, S.J.; NOUER, S.A.; PAPAIORDANOU, P.M.; GOVEIA, A et al. Endemic regions of paracocci-dioidomycosis in Brazil: a clinical and epidemiologic study of 584 cases in the southeast regions. Am. J. Trop. Med. Hyg., v.61, p. 390-394, 1999.

BOCCA, A L.; HAYASSHI, E.E.; PINHEIRO, A. G.; FURIANETTO, A.B.; CAMPANELLI, A. P.; CUNHA, F.Q.; FIGUEIREDO, F. Treatement of Paracoccidioides brasiliensis - infected mice with a nitric oxide inhibitor prevents the failure of cellmediated immune responses. J. Immunol., v. 161, p. 3056-3063, 1998.

BOCCA, A.L.; SILVA, M.F.; SILVA, C.L.; CUNHA, F.Q.; FIGUEIREDO, F. Macrophage expression of class II major histocompatibility complex gene products in Paracoccidioides brasiliensis infected mice. Am. J. Trop. Med. Hyg., v.61, p. 280-287, 1999.

BOGDAN, C.; VODOVOTZ, Y.; PAIK, J.; XIE, Q.W.; NATHAN, C. Mechanism of suppresion of nitric oxide synthase expression by interleukin-4 in primary mouse macrophages. J. Leukoc. Biol., v. 55, p. 227-233, 1994.

BRITTO, T.; FURTADO, J.S.; CASTRO, R.M.; MANINI, M. Intraepithelial parasitism as an infection mechanism in human paracoccidioidomycosis. Virchows Arch. A, Pathol. Anat., v. 361, p. 129-138, 1973. 
BROWN, G.D.; GORDON, S. Fungal beta-glucans and mammalian immunity. Immunity, v. 19, p. 311-315, 2003.

BRUMMER, E; HANSON, L.H.; STEVENS, D.A.: Gamma-interferon activation of macrophages for killing of Paracoccidioides brasiliensis: evidence for non-oxidative mechanisms. Int. J. Immunopharmacol., v. 10, p. 945-952, 1988.

BRUMMER, E.; KURITA, N.; YOSHIDA, S.; NISHIMURA, K.; MIYAJI, M. Killing of Histoplasma capsulatum by $\gamma$-interferon-activated human monocyte-derived macrophages: evidence for a superoxide anion-dependent mechanism. J. Med. Microbiol., v. 35, p. 29-34, 1991.

BRUMMER, E.; STEVENS, D.A. Antifungal mechanisms of activated murine bronchoalveolar or peritoneal macrophages for Histoplasma capsulatum. Clin. Exp. Immunol., v. 102, n. 1, p. 65-70, 1995.

BRUNELLI, L.; CROW, J.P.; BECKMAN, J.S. The comparative toxicity of nitric oxide and peroxynitrite to Escherichia coli. Arch. Biochem. Biophys., v. 316, p. 327-334, 1995.

CABRERA, R. An immunomodulatory role for $\mathrm{CD} 4^{+} \mathrm{CD} 25^{+}$regulatory $\mathrm{T}$ lymphocytes in hepatitis C virus infection. Hepatology, v. 40, p. 1062-1071, 2004.

CALICH, V.L.; KIPNIS, T.L.; MARIANO, M.; NETO, C.F.; DIAS DA SILVA, W.D. The activation of the complement system by Paracoccidioides brasiliensis in vitro: its opsonic effect and possible significance for an in vivo model of infection. Clin. Immunol. Immunophatol., v.12, p. 21-30, 1979.

CALICH, V. L. G.; SINGER-VERMES, L. M.; SIQUEIRA, A. M.; BURGER, E. Susceptibility and resistance of inbred mice to Paracoccidioides brasiliensis. Br. J. Exp. Pathol., v. 66, p. 585-594, 1985.

CALICH, V.L.G.; SINGER-VERMES, L.M.; RUSSO, M.; VAZ, C.A.C.; BURGER, E. Immunogenetics is paracoccidioidomycosis. In: FRANCO, M.; LACAZ, C.S.; RESTREPO-MORENO, A.; DEL NEGRO, G. (Ed.). Paracoccidioidomycosis. Boca Raton Florida: CRC Press, 1994. p. 151-173.

CALICH, V.L.G.; PINA, A.; FELONATO, M.; BERNARDINO, S.; COSTA, T.A.; LOURES, F.V. Toll-like receptors and fungal infections: the role of TLR2, TLR4 and MyD88 in paracoccidioidomycosis. FEMS Immunol. Med. Microbiol., v. 53, p.1-7, 2008. 
CAMPANELLI, A.P.; MARTINS, G.A.; SOUTO, J.T.; PEREIRA, M.S.F.; LIVONESI, M.C.; MARTINEZ, R.; SILVA, J.S. Fas-Fas ligand (CD95-CD95L) and cytotoxic T lymphocyte antigen-4 engagement mediate $\mathrm{T}$ cell unresponsiveness in patients with paracoccidioidomycosis. J. Infect. Dis., v. 187, p. 1496-1505, 2003.

CANO, L. E.; KASHINO, S. S.; ARRUDA, C.; ANDRÉ, D.; XIDIEH, C. F.; SINGERVERMES, L. M.; VAZ, C. A. C.; BURGER, E.; CALICH, V. L. G. Protective role of gamma interferon in experimental pulmonary paracoccidioidomycosis. Infect. Immun., $\mathrm{v}$. 66, p. 800-806, 1998.

CANO, L. E.; SINGER-VERMES, L. M.; VAZ, C. A. C.; RUSSO, M.; CALICH, V. L. G. Pulmonary paracoccidioidomycosis in resistant and susceptible mice: relationship among progression of infection, bronchoalveolar cell activation, cellular immune response, and specific isotype patterns. Infect. Immun., v. 63, p. 1777-1783, 1995.

CANO, L.E.; SINGER-VERMES, L.M.; COSTA, T.A.; MENGEL, J.O.; XIDIEH, C.F.; ARRUDA, C.; ANDRÉ, D.C.; VAZ, C.A.C.; BURGER, E.; CALICH, V.L.G. Depletion of $\mathrm{CD}^{+} \mathrm{T}$ cells in vivo impairs host defense of mice resistant and susceptible to pulmonary paracoccidioidomycosis. Infect. Immun., v. 68, p. 352-359, 2000.

CAVASSANI, K.A.; CAMPANELLI, A.P. MOREIRA, A.P.; VANCIM, J.O.; VITALI, L.H.; MAMEDE, R.C. MARTINEZ, R.; SILVA, J.S. Systemic and local characterization of regulatory T cells in chronic fungal infection in humans. J. Immunol., v. 177, p. 58115818, 2006.

CARMO, J.P.M.; DIAS-MELICIO, .L.A.; CALVI, S.A.; PERAÇOLI, M.T.S.; SOARES, A.M.V.C. TNF-alpha activates human monocytes for Paracoccidioides brasiliensis killing by an $\mathrm{H}_{2} \mathrm{O}_{2}$-dependent mechanism. Med. Mycol., v. 44, p. 363-368, 2006.

CARSON, F.L.; MARTIN, J.H.; LUNN, J.A. Formalin fixation for electron microscopy: are-evaluation. Am. J. Clin. Pathol., v. 59, p. 363-373, 1973.

CAYATTE, A. J.; MAGNER, F.; COHEN, R.A. VCAM-1 induction by TNF in human umbilical vein endothelial cells: a regulatory mechanism sensitive to intracellular generation of reactive oxygen species and exogenous nitric oxide. FASEB J., v. 11, p. 2647, 1997.

CHAKOUR, R.; GULER, R.; BUGNON, M.; ALLENBACH, C.; GARCIA, I.; MAUEL, J.; LOUIS, J.; TACCHINI-COTTIER, F. Both the Fas ligand and inducible nitric oxide synthase are needed for control of parasite replication with lesions in mice infected with Leishmania major whereas the contribution of tumor necrosis factor is minimal. Infect. Immun., v. 71, p. 5287-5295, 2003. 
CHAN, S.H.; PERUSSIA, B.; GUPTA, J.W.; KABAYASHI, M.; POSPISIL, M.; YOUNG, H.A.; WOLF, S.F.; TRINCHIERI, G. Induction of interferon- $\gamma$ production by natural killer stimulatory factor: Characterization of the responder cell and synergy with other inducers. J. Exp. Med., v. 173, p. 869-879, 1991.

CHIARELLA, A.P.; ARRUDA, C.; PINA, A.; COSTA, T.A.; FERREIRA, R.C.; CALICH, V.LG..: The relative importance of $\mathrm{CD}^{+}$and $\mathrm{CD} 8^{+} \mathrm{T}$ cells in immunity to pulmonary paracoccidioidomycosis. Microbes Infect., v. 9: p. 1078-88, 2007.

CHU, H.W.; WANG, J.M.; BOUTET, M.; LAVIOLETTE, M. Tumor necrosis factor- $\alpha$ and interleukine 1- $\alpha$ expression in a murine model of allergic bronchopulmonary aspergillosis. Lab. Anim. Sci., v. 46, p. 42-47, 1996.

CO, D.O; HOGAN, L.H.; KIM. I.S.; SANDOR, M.: T cell contributions to the different phases of granuloma formation. Immunol. Lett., v. 92, p. 135-142, 2004.

CONCEIÇÃO-SILVA, F.; HAHNE, M.; SCHRÖTER, M.; LOUIS, J.; TSCHOPP, J. The resolution of lesions induced by Leishmania major in mice requires a function Fas (APO1, CD95) pathway of citoxicity. Eur. J. Immunol., v. 28, p. 237-245, 1998.

CUMBERBATCH, M.; KIMBER, I. Tumor necrosis factor-alpha is required for accumulation of dendritic cells in draining lymph nodes and for optimal contact sensitization. Immunology, v. 84, p. 31-35, 1995.

CUNHA, F.Q.; MONCADA, S.; LIEW, F.Y. Interleukin-10 (IL-10) inhibits the induction nitric oxide synthase by interferon-gamma in murine macrophage. Biochem. Biophys. Res. Commun., v. 182, p. 1155-1159, 1992.

DALTON, D.K.; HAYNES, L.; CHU, C.Q.; SWAIN, S.L.; WITTMER, S. Interferon $\gamma$ eliminates responding CD4 $\mathrm{T}$ cells during Mycobacterial infection by inducing apoptosis of activated CD4 T cells. J. Exp. Med., v. 192, p. 117-122, 2000.

DEN HAAN, J.M.M.; LEHAR, S.M.; BEVAN, M.J. CD8+ but not CD8- dendritic cells cross-prime cytotoxic T cells in vivo. J. Exp. Med., v. 192, p. 1685-1696, 2000.

DIECKMANN, D.H.; PLOTTNER, H.; BERCHTOLD, S.; BERGER, T.; SHULER, G. Ex vivo isolation and characterization of $\mathrm{CD} 4^{+} \mathrm{CD} 25^{+} \mathrm{T}$ cells with regulatory properties from human blood. J. Exp. Med., v. 193, p. 1303-1310, 2001. 
DING, A.H.; NATHAN, C.F.; STUEHR, D.J. Release of reactive nitrogen intermediates and reactive oxygen intermediates from mouse peritoneal macrophages. Comparasion of activating cytokines and evidence of independent production. J. Immunol., v. 141, p. 2407-2412, 1988.

DITTMER, U. Function impairment of $\mathrm{CD}^{+} \mathrm{T}$ cells by regulatory $\mathrm{T}$ cells during persistent retroviral infection. Immunity, v. 20, p. 293-303, 2004.

DRAKESMITH, H.; CHAIN, B.; BEVERLEY, P. How can dendritic cells cause autoimmune disease? Immunol. Today, v. 21, p. 214-217, 2000.

EINSENSTEIN, T.K. Implications of Salmonella -induced nitric oxide (NO) for host defense and vaccines: NO, an antimicrobial, antitumor, immunosuppressive and immunoregulatory molecule. Microb. Infect., v. 3, p 1223-1231, 2001.

EINSENSTEIN, T.K.; KILLAR, L.M.; STOCKER, B.A .D., SULTZER, B.M. Cellular immunity induced by avirulent Salmonella in LPS-defective C3H/Hej mice. J. Immunol., v. 133, p. 958-961, 1984.

FAICAL, S.; BORRI, M.L.; HAUACHE, O.M.; AIZEN, S. Addison's disease caused by Paracoccidioides brasiliensis: diagnosis by needle aspiration biopsy of the adrenal gland. Am. J. Roentgenol., v. 166, p. 461-462, 1996.

FAVA NETTO, C. Estudos quantitativos sobre a fixação do complemento na blastomicose sul-americana, com antígeno polissacarídeo. Arq. Cir. Clin. Exp. São Paulo, v. 18, p. 197-254, 1955.

FERNANDES, K.S.S.; NETO, E.H.; BRITO, M.M.S.; SILVA, J.S.; CUNHA, F.Q.; FIDALGO, C.B. Dentrimental role of endogenous nitric oxide in host defence against Sporotrix schenckii. Immunology, v. 123, p. 469-479, 2008.

FIDEL, P.L.; SOBEL, J.D. The role of cell- mediated immunity in candidiasis. Trends Microbiol., v. 2, p. 202-206, 1994.

FLYNN，J.L.; GOLDSTEIN，M.M.; CHAN，J.; TRIEBOLD，K.J.; PFEFFER， K.; LOWENSTEIN, C.J.; SCHREIBER, K.; MAK, T.W.; BLOOM, B.R. : Tumor necrosis factor-alpha is required in the protective immune response against Mycobacterium tuberculosis in mice. Immunity, v. 2, p. 561-572, 1995. 
FONTENOT, J.D.; RUDENSKY, A. A well adapted regulatory contrivance: regulatory T cell development and the Forkhead family transcription factor Foxp3. Nat. Immunol., v. 6, p. 331-337, 2005.

FORNAZIM, M.C.; BALTHASAR, A.; QUAGLIATO, R.; MAMONI, R.L.; GARCIA, C.; BLOTTA, M.H. Evaluation of bronchoalveolar cells in pulmonary paracoccidioidomycosis. Eur. Respir. J., v. 22, p. 895-899, 2003.

FRANCO, M.F. Host parasite relationship in paracoccidioidomycosis. J. Med. Vet. Mycol., v. 25, p. 5-18, 1987.

FRANCO, M.F.; MENDES, R.P.; MOSCARDI-BACCHI, M.; REZKALLAH-IWASSO, M.T.; MONTENEGRO, M.R. Paracoccidioidomycosis. Baillières Clin. Trop. Med. Comum. Dis., v. 4, p. 185-220, 1989.

FUJIGAKI, S.; SAITO, K.; TAKEMURA, M.; MAEKAWA, N.; YAMADA, Y.; WADA. H.; SEISHIMA, M. L-tryptophan-L-kynurenine pathway metabolism accelerated by Toxoplasma gondii infection is abolished in gamma interferon-gene-deficient-mice: crossregulation between inducible nitric oxide synthase and indoleamine 2,3-dioxygenase. Infect. Immun., v. 70, p. 779-786, 2002.

GEROSA, F. CD4+T cell clones producing both interferon-gamma and interleukin-10 predominate in bronchoalveolar lavages of active pulmonary tuberculosis patients. Clin. Immunol., v. 92, p. 224-234, 1999.

GOLDANI, L.Z.; SUGAR, A.M. Paracoccidioidomycosis and AIDS: an overview. Clin. Infect. Dis., v. 21, p. 1275-1281, 1995.

GOMES, M.S.; FLORIDO, M;, PAIS, T.F.; APPELBERG, R.: Improved clearance of Mycobacterium avium upon disruption of the nitric oxide synthase gene. J. Immunol., v. 162, p. 6734-6739, 1999.

GONZALEZ, A.; DE GREGORI W.; VELEZ, D.; RESTREPO, A.; CANO, L.E. Nitric oxide participation in the fungicidal mechanism g gamma-interferon- activated murine macrophages against Paracoccidioides brasiliensis conidia. Infect. Immun., v. 68, p. 2546-2552, 2000.

GONZALEZ, A.; ARISTIZABAL, B.H.; GOMEZ, E.C.; RESTREPO, A.; CANO, L.E. Short report: Inhibition by tumor necrosis factor-alpha activated macrophages of the transition of Paracoccidioides brasiliensis conidia of yeast cells through a mechanism independent of nitric oxide. Am. J. Trop. Med. Hyg., v. 71, p. 828-830, 2004. 
GONZALEZ, A.; LENZI, H.L.; MOTTA, E.M.; CAPUTO, L.; SAHAZA, J.H.; COCK, A.M.; RUIZ, A.C.; RESTREPO, A.; CANO, L.E. Expression of adhesion molecules in lungs of mice infected with Paracoccidioides brasiliensis conidia. Microbes Infect., v. 7, n.4, p. 666-673, 2005.

GORDON S. Pattern recognition receptors: doubling up for the innate immune responses. Cell, v.111, p. 927-930, 2002.

GREEN, E.A.; GORELIK, L.; MCGREGOR, C.M.; TRAN, E.H.; FLAVELL, R.A. $\mathrm{CD} 4^{+} \mathrm{CD} 25^{+} \mathrm{T}$ regulatory cells control anti-islet $\mathrm{CD} 8^{+} \mathrm{T}$ cells through $\mathrm{TGF}-\beta$-receptor interactions in type 1 diabetes. Proc. Natl. Acad. Sci. USA, v. 100, p. 10878-10883, 2003.

GREWAL, I.S.; FLAVELL, R.A. A central role of CD40 ligand in the regulation of CD4+ T cell responses. Immunol. Today, v. 17, p. 410-414, 1996.

GROHMANN, U.; BIANCHI, R.; BELLADONNA, M.L.; SILLA, S.; FALLARINO, F.; FIORETTI, M.C.; PUCCETTI, P. IFN- $\gamma$ inhibits presentation of a tumor/self peptide by CD8 $\alpha$ - dendritic cells via potentiation of the CD8 $\alpha+$ subset. J. Immunol., v. 165, p. 1357$1363,2000$.

GROHMANN, U.; FALLARINO, F.; BIANCHI, R.; BELLADONA, M.L.; VACCA, C.; ORABONA, C.; UYTENHOVE, C.; FIORETTI, M.C.; PUCETTI, P. IL-6 inhibits tolerogenic function of $\mathrm{CD} 8 \alpha+$ dendritic cells expressing indoleamine 2,3-dioxygenase. $\mathbf{J}$. Immunol., v. 167, p. 708-714, 2001.

GULER, R.; OLLEROS, M.L.; VESIN, D.; PARANOV, R.; GARCIA, I. Differential effects of total and partial neutralization of tumor necrosis factor on cell-mediated immunity to Mycobacterium bovis BCG infection. Infect. Immun., v. 73, p. 3668-3667, 2005.

HAERYFAR, S.M.M.; DIPAOLO, R.J.; TSCHARKE, D.C.; BENNINK, J.R.; YEWDELL, J.W. Regulatory $\mathrm{T}$ cells suppress $\mathrm{CD} 8^{+} \mathrm{T}$ cell response induced by direct priming and cross-priming and moderate immunodominance disparities. J. Immunol., v. 174, p. 3344-3351, 2005.

HAMACHER, J.; SCHABERG, T. Adhesion molecules in lung disease. Lung, v. 172, p. 189-213, 1994.

HAMMAD, H.; DE VRIES, V.C.; MALDONADO-LOPEZ, R.; MOSER, M.; MALISZEWSKI, C.; HOOGSTEDEN, H.C.; LAMBRECHT, B.N. Differential capacity 
of $\mathrm{CD}^{+}$alpha or $\mathrm{CD}^{-}$alpha dendritic cell subsets to prime for eosinophilic airway inflammation in the T-helper type 2-prone milieu of the lung. Clin. Exp. Allergy., v. 34, p.1834-40, 2004.

HERRING, A.C.; LEE, J.; MCDONALD, R.A.; TOEWS, G.B.; HUFFNAGLE, G.B. Induction of interleukin-12 and gamma interferon requires tumor necrosis factor alpha for protective T1-cell-mediated immunity to pulmonary Cryptococcus neoformans infection. Infect. Immun., v. 70, p. 2959-2964, 2002.

HERRING, A.C.; FALKOWSKI, N.R.; CHEN, G.H.; MACDONALD, R.A.; TOEWS G.B.; HUFFNAGLE, G.B. Transient neutralization of tumor necrosis factor alpha can produce a chronic fungal infection in an immunocompetent host: potencial role of immature dendritic cells. Infect. Immun., v. 73, p. 39-49, 2005.

HISAEDA, H. Escape of malaria parasites from host immunity requires $\mathrm{CD} 4{ }^{+} \mathrm{CD} 25^{+}$ regulatory T cells. Nat. Med., v. 10, p. 29-30, 2004.

HOCHREIN, H.; SHORTMAN, K.; VREMEC, D.; SCOTT, B.; HERTZOG, P.; O'KEEFFE, M. Differential production of IL-12, IFN- and INF-by mouse dendritic cell subsets. J. Immunol., v. 166, p. 5448-5455, 2001.

HONG, M.; ZHU, Q. Macrophages are activated by 17 beta-estradiol: possible permission role in endometriosis. Exp. Toxicol. Pathol., v. 55, n. 5, p. 385-391, 2004.

HORI, S.; NOMURA, T.; SAKAGUCHI, S. Control of regulatory T cell development by the transcription factor Foxp3. Science, v. 299, p. 1057-1061, 2003.

HUFFNAGLE, G.B.; TOEWS, G.B.; BURDICK, M.D.; BOYD, M.B.; MCALLISTER, K.S.; MCDONALD, R.A.; KUNKEL, S.L.; STRIETER, R.M. Afferent phase production of TNF- $\alpha$ is required for the development of protective T cell immunity to Cryptococcus neoformans. J. Immunol., v. 157, p 4529-4536, 1996.

HUFFNAGLE , G.B.; CHEN, G.H.; CURTIS, J.L.; MCDONALD, R.A.; STRIETER, R.M.; TOEWS, G.B. Downregulation of the afferent phase of T cell-mediated pulmonary inflammation and immunity by a high melanin-producing strain of Cryptococcus neoformans. J. Immunol., v. 155, p. 3507-3516, 1995.

IYODA, T.; SHIMOYAMA, S.; LIU, K.; OMATSU, Y.; AKIYAMA, Y.; MAEDA, Y.; TAKAHARA, K.; STEINMAN, R.M.; INABA, K. The CD8+ dendritic cell subset selectively endocytoses dying cells in culture and in vivo. J. Exp. Med., v. 195, p. 12891302, 2002. 
JACKSON, S.H.; GALLIN, J.I.; HOLLAND, S.M. The p47 phox mouse knock-out model of chronic granulomatous disease. J. Exp. Med., v. 182, p. 751-758, 1995.

JANEWAY, C.A. Jr; MEDZHITOV, R. Innate immune recognition. Annu. Rev. Immunol., v.20, p.197-216, 2002.

JUNG, S.; UNUTMAZ, D.; WONG, P.; SANO, G.; DE LOS SANTOS, K.; SPARWASSER, T.; WU, S.; VUTHOORI, S.; KO, K.; ZAVALA, F. In vivo depletion of CD11c(+) dendritic cells abrogates priming of CD8(+) T cells by exogenous cellassociated antigens. Immunity, v. 17, p. 211-220, 2002.

KASHINO, S. S.; FAZIOLI, R. A.; MOSCARDI-BACCHI, M.; FRANCO, M.; SINGERVERMES, L. M.; CALICH, V. L. G.; BURGER, E.; SINGER-VERMES, L. M. In vivo and in vitro characteristics of six Paracoccidioides brasiliensis strains. Mycopathologia, v. 92, p. 173-178, 1985.

KEANE, J.; GERSHON, S.; WISE, R.P. Tuberculosis associated with infliximab, a tumor necrosis factor alpha-neutralizing agent. N. Engl. J. Med., v. 345, p. 1098-1104, 2001.

KENNEDY, M.K.; PICHA, K.S.; FANSLOW, W.C. CD40ICD40 ligand interactions are required for $\mathrm{T}$ cell-dependent production of interleukin-12 by mouse macrophages. Eur. J. Immunol., v. 26, p. 370-378, 1996.

KINDLER, V.; SAPPINO, A.P.; GRAU, G.E.; PIGUET, P.F.; VASSALI, P. The inducing role of tumor necrosis factor in the development of bactericidal granulomas during BCG infection. Cell, v. 56, p. 731-740, 1989.

KNOWLES, R.G.; MONCADA, S. Nitric oxide synthases in mammals. Biochem. J., v. 298, p. 249-258, 1994.

KNOWLES, R.G. Nitric oxide synthases. Biochem. Soc. Trans., v. 24, p. 875-878, 1996.

KONNO, A.Y.C.; MARICATO, J.T.; KONNO, F.T.C.; MARIANO, M.; LOPES, J.D. Peptides from Paracoccidioides brasiliensis GP 43 inhibit macrophage function and inflammatory response. Microbes Infect., v. 11, p. 92-99, 2009.

LEMLE, A.; WANKE, B.; MANDEL, M.B. Pulmonary localization of Paracoccidioidomycosis: Lung functions atudies before and after treatment. Rev. Inst. Med. Trop. São Paulo, v. 25, p.73-78, 1983. 
LIESENFELD, O.; KOSEK, J.C.; SUSUKI, Y. Gamma interferon induces Fas-dependent apoptosis of Peyer's patch $\mathrm{T}$ cells in mice following peroral infection with Toxoplasma gondii. Infect. Immun., v. 65, p. 4682-4689, 1997.

LINDELL, D.M.; MOORE, T.A.; MCDONALD, R.A.; TOEWS G.B.; HUFFNAGLE, G.B. Distinct compartmentalization of $\mathrm{CD}^{+}{ }^{+} \mathrm{T}$-cell effertor function versus proliferative capacity during pulmonary cryptococcosis. Am. J. Pathol., v. 168, p. 847-855, 2006.

LOOSE, D.S.; STOVER, E.P.; RESTREPO, A.; STEVENS, D.A.; FELDMAN, D. Estradiol binds to a receptor-like cytosol protein and inhibits a biological response in Paracoccidioides brasiliensis. Proc. Natl. Acad. Sci. USA, v. 80, p. 7659-7663, 1983.

MACMICKING, J.D.; NORTH, R.J.; LACOURSE, R.; MUDGETT, J.; SHAH, S.K.; NATHAN, C.F. Identification of NOS2 as a protective locus against tuberculosis. Proc. Natl. Acad. Sci. USA, v. 94, p. 5243-5248, 1997.

MACMICKING, J.; XIE, Q.W.; NATHAN, C. Nitric oxide and macrophage function. Annu. Rev. Immunol., v. 15, p. 323-350, 1997.

MAGALHÃES, A.E.A.; GUERRINI, R. Roentgenographic patterns of chest lesions. The use of computerized tomography in paracoccidioidomycosis. In: FRANCO, M.; LACAZ, C.S.; RESTREPO-MORENO, A.; DEL NEGRO, G. (Ed.). Paracoccidioidomycosis. Boca Ratton: CRCPress, 1994. v. 20.

MALDONADO-LOPEZ, R.; DE SMEDT, T.; MICHEL, P.; GODFROID, J.; PAJAK, B.; HEIRMAN, C.; THIELEMANS, K.; LEO, O.; URBAIN, J.; MOSER, M. CD8 $\alpha+$ and CD8 $\alpha$ - subclasses of dendritic cells direct the development of distinct $\mathrm{T}$ helper cells in vivo. J. Exp. Med., v. 189, p. 587-592, 1999.

MAMONI, R.L.; NOUER, A.S.; OLIVEIRA, S.J.; MUSATTI, C.C.; ROSSI, C.L.; CAMARGO, Z.P.; BLOTTA, M.H.S.L. Enhanced production of specific IgG 4, IgE and TGF-beta in sera from patients with the juvenile form of paracoccidioidomycosis. Med. Mycol., v. 40, p. 153-159, 2002.

MAMONI, R.L.; BLOTTA, M.H.S.L. Flow-cytometric analysis of cytokine production in human paracoccidioidomycosis. Cytokine, v. 35, p. 207-216, 2006

MANSOUR, M.K.; LEVITZ, S.M. Interations of fungi with phagocytes. Curr. Opin. Microbiol., v. 5, p. 359-365, 2002. 
MARR, K.A.; PATTERSON, T.; DENNING, D. Aspergillosis. Pathogenesis, clinical manifestations and therapy. Infect. Dis. Clin. North Am., v. 16, p. 875-894, 2002.

MARTIN-FONTECHA, A.; SEBASTIANI. S.; HOPKEN, U.E.; UGUCCIONI, M.; LIPP, M.; LANZAVECCHIA, A.; SALLUSTO, F. Regulation of dendritic cell migration to the draining lymph node: impact on T lymphocyte traffic and priming. J. Exp. Med., v. 198, p. 615-621, 2003.

MARTINS, G.A.; VIEIRA, L.Q.; CUNHA, F.Q.; SILVA, J.S. Gamma interferon modulates CD95 (Fas) and CD95 ligand (Fas L) expression and nitric oxide-induced apoptosis during the acute phase of Trypanosoma cruzy infection: a possible role in immune response control. Infect. Immun., v. 67, p. 3864-3871, 1999.

MAURI, D.; PICHLER, W.J. Involvement of CD80 in the generation of CD4+ cytotoxic T cells. Immunol. Res., v. 15, p. 126-140, 1996.

MCCALL, T.B.; PALMER, R.M.; MONCADA, S. Interleukin-8 inhibits the induction of nitric oxide synthase in rat paritoneal neutrophils. Biochem. Biophys. Res. Commun., v. 186, p. 680-685, 1992.

MCKINNEY, M.M.; PARKINSON, A. A simple, non-chromatographic procedure to purify immonoglobulins from serum ans ascites fluid. J. Immunol. Methods, v. 96, p. 271-278, 1987.

MEHRAD, B.; STRIETER, R.M.; STANDIFORD, T.J. Role of TNF-alpha in pulmonary host defense in murine invasive aspergillosis. J. Immunol., v. 162, p. 1633-1640, 1999.

MEJRI, N.; GOTTSTEIN B. Intraperitoneal Echinococcus multicolaris infection in C57BL6 mice affects CD40 and B7 costimulator expression on peritoneal macrophages and impais peritoneal T cell activation. Parasite Immunol., v. 28, p. 373-385, 2006.

MELONI-BRUNERI, L.H.; CAMPA, A.; ABDALLA, D.S.; CALICH, V.L.G.; LENZI, H.L.; BURGER, E. Neutrophil oxidative metabolism and killing of $P$. brasiliensis after air pouch infection of susceptible and resistant mice. J. Leukoc. Biol., v. 59, p. 526-533, 1996.

MENDES-GIANINNI, M.J.S.; BUENO, J.P.; SHIKANAI-YASUDA, M.A.; FERREIRA, W.; MASUDA, A., Detection of the 43,000 molecular weight glycoprotein in sera of patients with paracoccidioidomycosis. J. Clin. Microbiol., v. 27, p. 2842-2845, 1989. 
MENDEZ, S.; RECKLING S.K.; PICCIRILLO, C.A.; SACKS, D.; BELKAID, Y. Role of $\mathrm{CD}^{+} \mathrm{CD} 25^{+}$regulatory $\mathrm{T}$ cells in reactivation of persistent leishmaniasis and control of concomitant immunity. J. Exp. Med., v. 200, p. 201-210, 2004.

MILLAR, A.E.; STERNBERG, J.; MCSHARRY, C.; WEI, X-Q.; LIEW, F.Y.; TURNER, C.M.R. T-cell responses during Trypanosoma brucei infections in mice deficient in inducible nitric oxide synthase. Infect. Immun., v. 67, p. 3334-3338, 1999.

MONCADA, S. Nitric oxide: physiology, pathophysiology and pharmacology. Pharmacol. Rev., v. 43, n. 2, p. 109-142, 1991.

MONTAGNOLI, C. B7/CD28-dependent $\mathrm{CD} 4^{+} \mathrm{CD} 25^{+}$regulatory $\mathrm{T}$ cells are essential components of the memory-protective immunity to Candida albicans. J. Immunol., v. 169, p. 6298-6308, 2002.

MOREIRA, A.P.; CAVASSANI, K.A.; TRISTAO, F.S.M.; CAMPANELLI, A.P.; MARTINEZ, R.; ROSSI, M.A.; SILVA, J.S. CCR5-dependent regulatory T cell migration mediates fungal survival and severe immunossupression. J. Immunol., v. 180, p. 30493056, 2008.

MOREIRA, A.P.; DIAS-MELICIO, L.A.; PERAÇOLI, M.T.S.; CALVI, S.A.; SOARES, A.M.V.C. Killing of Paracoccidioides brasiliensis yeats cells by IFN- $\gamma$ and TNF- $\alpha$ activated murine peritoneal macrophages: evidence of $\mathrm{H}_{2} \mathrm{O}_{2}$ and $\mathrm{NO}$ effector mechanisms: Mycopathology, v. 166, p. 17-23, 2008.

MULLEY, W.R.; PATERSON, D.J.N. Indoleamine 2,3-dioxygenase in transplantation. Nefrology, v. 13, p. 204-211, 2008.

MURRAY, H.W.; LITTMAN, M.L.; ROBERTS, R.B. Disseminated paracoccidioidomycosis (South American Blatomycosis) in the United States. Am. J. Med., v. 56, p. 209-220, 1974.

NASCIMENTO, F.R.F.; CALICH, V.L.G.; RODRIGUEZ, D.; RUSSO, M. Dual role of nitric oxide in Paracoccidioidimycosis: essential for resistance, but overproduction associated with susceptibility. J. Immunol., v. 168, p. 4593-4600, 2002.

NAKAMURA, K.; KITANI, A.; STROBER, W. Cell contact-dependent immunossupression by $\mathrm{CD} 4+\mathrm{CD} 25+$ regulatory $\mathrm{T}$ cells is mediated by surface-bound transforming growth factor $\beta$. J. Exp. Med., v. 194, p. 629-644, 2001. 
NAKAMURA, K.; KITANI, A.; FUSS, I.; PEDERSEN, A.; HARADA, N.; NAWATA, H.; STROBER, W. TGF- $\beta$ plays an important role in the mechanism of $\mathrm{CD} 4{ }^{+} \mathrm{CD} 25^{+}$ regulatory $T$ cell activity in both humans and mice. J. Immunol., v. 172, p. 834-842, 2004.

NETEA, M.G.; VAN DER GRAAF, C.A.; VONK, A.G.; VERSCHUEREN, I.; VAN DER MEER, J.W.; KULLBERG, B.J. The role of toll-like receptor (TLR) 2 and TLR4 in the host defense against disseminated candidiasis. J. Infect. Dis., v. 186, p. 1377-1379, 2002.

NEUENHAHN, M.; KERKSIEK, K.M.; NAUERTH, M.; SUHRE, M.H.; SCHIEMANN, M.; GEBHARDT, F.E.; STEMBERGER, C.; PANTHEL, K.; SCHRÖEDER, S.; CHAKRABORTY, T.; JUNG, S.; HOCHREIN, H.; RÜSSMANN, H.; BROCKER, T.; BUSCH, D.H. CD8 $\alpha+$ dendritic cells are required for efficient entry of Listeria monocytogenes into the spleen. Immunity, v. 25, p. 619-630, 2006.

NEWORAL, E.P.M.; ALTEMANI, A.; MAMONI, R.L.; NORONHA, I.L.; BLOTTA, M.H.S.L. Immunocytochemical localization of cytokines and inducible nitric oxide synthase (iNOS) in oral mucosa and lymph nodes of patients with paracoccidioidomycosis. Cytokine, v. 21, p.234-241, 2003.

NIEDBALA, W.; WEI, X-Q.; PIEDRAFITA, D.; XU, D.; LIEW, F.Y. Effects of nitric oxide on the induction and differentiation on Th1 cells. Eur. J. Immunol., v. 29, p. 2498$2505,1999$.

NIEDBALA, W.; CAI. B.; LIU, H.; PITMAN, N.; CHANG, L.; LIEW, F.Y. Nitric oxide induces $\mathrm{CD}^{+} \mathrm{CD} 25^{+}$Foxp3 regulatory $\mathrm{T}$ cells from $\mathrm{CD}^{+} \mathrm{CD} 25^{-} \mathrm{T}$ cells via p53, IL-2, and OX40. Proc. Natl. Acad. Sci. USA, v. 104, p. 15478-15483, 2007.

NIINOBU, T.; FUKUO, K.; YASUDA, O.; TSUBAKIMOTO, M.; MOGI, M.; NISHIMAKI, H.; MORIMOTO, S.; OGIHARA, T. Negative feddback regulation of activated macrophages via Fas-mediated apoptosis. Am. J. Physiol. Cell Physiol., v. 279, p. 504-509, 2000.

OSTROWSKI, M.A. Quantitative and qualitative assessment of human immunodeficiency virus type 1 (HIV-1)-specific CD4+T cell immunity to gag in HIV-1 infected individuals with differential disease progression: reciprocal interferon-gamma and interleukin-10 responses. J. Infect. Dis., v. 184, p. 1268-1267, 2001.

PICK, E; MIZEL, D. Rapid microassays for the measurement of superoxide and hydrogen peroxide production by macrophages in culture using an automatic enzyme immunoassay reader. J. Immunol. Methods, v.46, p. 211-226, 1981. 
PINA, A.; FERREIRA, R.C.V.; MADLUM, E.E.W.M.; VAZ, C.A.C.; KELLER, A.C.; CALICH, V.L.G. Absence of interleukin-4 determines less severe pulmonary Paracoccidioidomycosis associated with impaired Th2 response. Infect. Immun., v. 72, p. 2369-2378, 2004.

PINA, A.; BERNARDINO, S.; CALICH, V.L.G. Alveolar macrophages from susceptible mice are more competent than those of resistant mice to control initial Paracoccidioides brasiliensis infection. J. Leukoc. Biol., v. 83, p. 1088-1099, 2008.

PLEBANSKI, M. Interleukin-10-mediated immunossupression by a variant CD4T cell epitope of Plasmodium falciparum. Immunity, v. 10, p. 651-660, 1999.

PLESSNER, H.L.; LIN, P.L.; KOHNO, T.; LOUIE, J.S.; KIRSCHNER, D.; CHAN, J.; FLYNN, J.L. Neutralization of tumor necrosis factor (TNF) by antibody but not TNF receptor fusion molecule exacerbates chronic murine tuberculosis. J. Infect. Dis., v. 195, p. 1643-1650, 2007.

POPI, A.F.; LOPES, J.D.; MARIANO, M. GP43 from Paracoccidioides brasiliensis inhibits macrophage functions. An evasion mechanism of the fungus. Cell. Immunol., v. 218, p. 87-94, 2002.

POWRIE, F.; READ, S.; MOTTET, C.; UHLIG, H.; MALOY, K. Control of immune pathology by regulatory T cells. Novartis Found. Symp., v. 252, p. 92-98, 2003.

PUCCIA, R.; SCHENKMAN, S.; GORIN, P.A.; TRAVASSO, L.R. Exocellular components of Paracoccidioides brasiliensis: identification of a specific antigen. Infect. Immun., v. 53, p. 199-206, 1986.

PULENDRAN, B.; LINGAPPA, J.; KENNEDY, M.; SMITH, J.; TEEPE, M.; RUDENSKY, A.; MALISZEWSKI, C.; MARASKOVSKY, E. Development pathways of dendritic cells in vivo: distinct function, phenotype, and localization of dendritic cells subsets in FLT3 ligand-treated mice. J. Immunol., v. 159, p. 2222-2231, 1997.

QUARATINO, S.; DUDDY, L.P.; LONDEI, M. Fully competent dendritic cells as inducers of T cell anergy in autoimmunity. Proc. Natl. Acad. Sci. USA, v. 97, p. 1091110916, 2000.

RAGHAVAN, S.; FREDIKSSON, M.; SVENNERHOLM, A.M.; HOLMGREN, J.; SURI-PAYER, E. Absence of $\mathrm{CD} 4{ }^{+} \mathrm{CD} 25^{+}$regulatory $\mathrm{T}$ cells is associated with a loss of regulation leading to increased pathology in Helicobater pylori-infected mice. Clin. Exp. Immunol., v. 132, p. 393-400, 2003. 
RAMSDELL, F.; SEAMAN, M.; MILLER, R.; PICHA, K.; KENNEDY, M.; LYNCH, D. Differential ability of Th1 and Th2 $\mathrm{T}$ cells to express Fas ligand and to undergo activation-induced cell death. Int. Immunol., v. 6, p. 1545-1553, 1994.

RANGER, A.M.; DAS, M.P.; KUCHROO, V.K.; GLIMCHER, L.H. B7-2 (CD86) is essential for the development of IL-4-producing T cells. Int. Immunol., v. 8, p. 15491560, 1996.

READ, S.; MALMSTROM V.; POWRIE, F. Cytotoxic T lymphocyte-associated antigen 4 plays an essential role in the function of CD25+CD4+ regulatory cells that control intestinal inflammation. J. Exp. Med., v.192, p. 295-302, 2000.

REIS E SOUSA, C. Activation of dendritic cells: translating innate to adaptative immunity. Curr. Opin. Immunol., v. 16, p. 21-25, 2004.

REMENTERÍA, A.; GARCÍA-TOBALINA, R.; SEVILLA, M.J. Nitric oxide-dependent killing of Candida albicans by murine peritoneal cells during an experimental infection. FEMS Immunol. Med. Microl., v. 11, p. 157-162, 1995.

RESNICK, M.B.; WELLER, P.F. Mechanism of eosinophil recruitment. Am. J. Respir. Cell Mol. Biol., v. 8, p. 349-355, 1993.

RESTREPO, A. The ecology of Paracoccidioides brasiliensis: a puzzle still unsolved. Sabouraudia, v. 23, p. 323-324, 1985.

RESTREPO-MORENO, A. Ecology of Paracoccidioides brasiliensis. In: FRANCO, M.; LACAZ, C.S.; RESTREPO-MORENO, A.; DEL NEGRO G. (Ed.). Paracoccidioidomycosis. Boca Ratton: CRC Press, 1994. Cap. 8.

RESTREPO, A. Morphological aspects of Paracoccidioides brasiliensis in lymph nodes: implications for the prolonged latency of paracoccidioidomycosis? Med. Mycol., v. 38, p. 317-322, 2000.

RITTER, U.; MEISSNER, A.; OTT, J.; KORNER, H. Analysis of the maturation process of dendritic cells deficient for TNF and lymphotoxin- $\alpha$ reveals an essential role for TNF. J. Leukoc. Biol., v. 74, p. 216-222, 2003.

RODRIGUES, D.R.; DIAS-MELICIO, L.A.; CALVI, S.A.; PERAÇOLI, M.T.S; SOARES, A.M.V.C. Paracoccidioides brasiliensis killing by IFN- $\gamma$, TNF- $\alpha$ and GM-CSF 
activated human neutrophils: role for oxygen metabolites. Med. Mycol., v.45, p. 27-33, 2007.

ROJAS, A.; DELGADO, R.; GLARIA, L.; PALACIOS, M.. Monocyte chemotactic protein-1 inhibits the induction of nitric oxide synthase in J774 cells. Biochem. Biophys. Res. Commun., v. 196, p. 274-279, 1993.

SAN-BLAS, F.; SAN-BLAS, G.; INLOW, D. Dimorphism in Paracoccidioides brasiliensis, Zentralbl. Bakteriol., v. 8, p. 23-28, 1980.

SCHINI, V.B.; DURANTE, W.; ELIZONDO, E.; SCOTT-BURDEN, T.; JUNQUERO, D.C.; SCHAFER, A. I.; VANHOUTTE, P.M. The induction of nitric oxide synthase activity is inhibited by TGF-beta, PDGFab and PDGF bb in vascular smooth muscle cells. Eur. J. Pharmacol., v. 216, p. 379-383, 1992.

SCHREIBER, O.; STEINWEDE, K.; DING, N.; SRIVASTAVA, M.; MAUS, R.; LÄNGER, F.; PROKEIN, J.; EHLERS, S.; WELTE, T.; GUNN, M.D.; MAUS, U.A. Mice that overexpress $\mathrm{CC}$ chemokine ligand 2 in their lungs show increased protective immunity to infection with Mycobacterium bovis bacille Calmette-Guérin. J. Infect. Dis., v.198: p. 1044-1054, 2008.

SCHULZ, O.; SOUSA, C.R.E. Cross-presentation of cell-associated antigens by CD8 $\alpha(+)$ dendritic cells is attributable to their ability to internalize dead cells. Immunology, v. 107, p. 183-189, 2002.

SHARTON-KERSTEN, T.; YAP, G.; MAGRAM., J.; SHER, A. Inducicle nitric oxide is essential for host control of persistent but not acute infection with the intracellular pathogen Toxoplasma gondii. J. Exp. Med., v. 185, p. 1261-1273, 1997.

SHEVACH, E.M. CD4 ${ }^{+} \mathrm{CD} 25^{+}$suppressor T cells: more questions than answers. Nat. Rev. Immunol., v. 2, p. 389-400, 2002.

SHIMIZU, J.; YAMAZAKI, S.; TAKAHASHI, T. Stimulation of CD25+CD4+ regulatory $\mathrm{T}$ cells through GITR breaks immunological self-tolerance. Nat. Immunol., $\mathrm{v}$. 3, p. 135-142, 2002.

SINGER-VERMES, L.M.; BURGER, E.; FRANCO, M.F.; MOSCARDI-BACCHI, M., MENDES-GIANINNI, M.J.S.; CALICH, V.L.G. Evaluation of the pathogenicity and immunogenicity of seven Paracoccidioides brasiliensis isolates in susceptible inbred mice. J. Med. Vet. Mycol., v. 26, p. 71-82, 1989. 
SINGER-VERMES, L.M.; CALDEIRA, C.B.; BURGER, E.; CALICH, V.L.G. Experimental murine paracoccidioidomycosis: relationship among dissemination of the infection, humoral and cellular responses. Clin. Exp. Immunol., v. 94, p. 75-79, 1993.

SOUTO, J. T.; FIGUEIREDO, F.; FURLANETTO, A.; PFEFFER, K.; ROSSI, M. A.; SILVA, J. S. Interferon-gamma and tumor necrosis factor-alpha determine resistance to Paracoccidioides brasiliensis infection in mice. Am. J. Pathol., v. 156, p. 1811-1820, 2000.

SUGAR, A.M.; BRUMMER, E.; STEVENS, A. Murine pulmonary macrophages: Evaluation of lung lavage fluids, miniaturized monolayers and candidacial activity. Ann. Rev. Respir. Dis., v. 127, p. 110-112, 1983.

SUGIMOTO, K. Suppression of HCV-specific T cells without differential hierarchy demonstrated ex vivo in persistent HCV infection. Hepatology, v. 38, p. 1437-1448, 2003.

TABORDA, C. P.; JULIANO, M. A.; PUCCIA, R.; FRANCO, M.; TRAVASSOS, L.R. Mapping of the T-Cell epitope in the major 43-kilodalton glycoprotein of Paracoccidioides brasiliensis which induces a Th1- response protective against fungal infection in BALB/c mice. Infect. Immun., v. 66, p. 786-793, 1998.

TAKEDA, K.; AKIRA, S. Toll-like receptors in innate immunity. Int. Immunol., v.1, p. $1-14,2005$.

THOMAS, S.R.; MOHR, D.; STOCKER, R. Nitric oxide inhibits indoleamine 2,3dioxygenase acitivity in interferon-gamma primed mononuclear phagocytes. J. Biol. Chem., v. 173, p. 566-572, 1994.

TRACEY, K.J.; CERAMI, A. Tumor necrosis factor, other cytokines and disease. Annu. Rev. Cell Biol., v. 9, p.317-343, 1993.

TRAVASSOS, L.R.; PUCCIA, R.; CISALPINO, P.; TABORDA, C.P.; RODRIGUES, E.G.; RODRIGUES, M.; SILVEIRA, J.F.; ALMEIDA, I.C. Biochemistry and molecular biology of the main diagnostic antigen of Paracoccidiodes brasiliensis. Arch. Med. Res., v. 26, p. 297-304, 1995.

TUFARIELLO, J.M.; CHAN, J.; FLYNN, J.L. Latent tuberculosis: mechanisms of host and bacillus that contribute to persistent infection. Lancet Infect. Dis., v. 3, p. 578-590, 2003. 
VASQUEZ-TORRES, A.; CARSON, J.J.; BALISH, E. Nitric oxide production does not directly increase macrophage candidacidal activity. Infect. Immun.., v. 63, p. 1142-1144, 1995.

VEEN, R.; DIETLIN, T.A.; GRAY, J.D.; GILMORE, W. Marcrophage-derived nitric oxide inhibits the proliferation of activated $\mathrm{T}$ helper cells and is induced during antigenic stimulation of resting T cells. Cell Immunol., v. 199, p. 43-49, 2000.

VILlALBA, H. Características microscópicas da paracoccidioidomicose bucal. Dissertation. Universidade de Campinas, Escola Superior de Agricultura Luiz de Queiroz, Piracicada, SP: UNICAMP, 1998.

YANG, Y.; WILSON, J.M. CD40-ligand-dependent T cell activation: requirement of B7CD28 signaling though CD40. Science, v. 273, p. 1862-1864, 1996.

WATANABE, K.; KAGAYA, K.; YAMADA, T.; FUKAZAWA, Y. Mechanism for candidacidal activity in macrophages activated by recombinant gamma-interferon. Infect. Immun., v. 59, p. 521-528, 1991.

WEI, X.Q.; CHARLES, I.G.; SMITH, A.; URE, J.; FENG, G.J.; HUANG, F.P.; XU, D.; MULLER, W.; MONOCADA, S.; LIEW, F.Y. Altered immune responses in mice lacking inducible nitric oxide synthase. Nature, v. 375, p. 408-411, 1995.

WHERRY, E.J.; TEICHGRÄBER, V.; BECKER, T.C.; MASOPUST, D.; KAECH, S.M.; ANTIA, R.; ANDRIAN, U.H.V.; AHMED, R. Lineage relationship and protective immunity of memory CD8T cell subsets. Nat. Immunol., v. 4, p. 225-234, 2003.

WOLF, J.E.; ABEGG, A.L.; TRAVIS, S.J.; KOBAYASHI, G.S.; LITTLE, J.R. Effects of Histoplasma capsulatum on murine macrophage functions: inhibition of macrophage priming, oxidative burst and antifungal activities. Infect. Immun., v. 57, p. 513-519, 1989.

WU-HSIEH, B.A.; CHEN, W.; LEE, H.J. Nitric oxide synthase expression in macrophages of Histoplasma capsulatum - infected mice is associated with splenocyte apoptosis and unresponsiveness. Infect. Immun., v. 66, p. 5520-5526, 1998. 


\section{ANEXO A - ARTIGO SUBMETIDO}

Artigo 1 BERNARDINO, S.; PINA, A.; FELONATO, M.; COSTA, T.A.; LEITE, K.R.M.; KELLER, A.C.; CALICH, V.L.G. Nitric Oxide Controls Fungal Loads and the Influx of Effector and Regulatory T Cells to the Lungs of Paracoccidioides brasiliensis Infected Mice. J. Immunol.

\section{ANEXO B - ARTIGOS PUBLICADOS}

Artigo 2 PINA, A.; BERNARDINO, S.; CALICH, V.L.G. Alveolar macrophages from susceptible mice are more competent than those of resistant mice to control initial Paracoccidioides brasiliensis infection. J. Leukoc. Biol., v. 83, p. 1088-1099, 2008.

Artigo 3 CALICH, V.L.G.; COSTA, T.A.; FELONATO, M.; ARRUDA, C.; BERNARDINO, S.; LOURES, F.V.; RIBEIRO, L.R.R.; VALENTE-FERREIRA, R.C.; PINA, A. Innate immunity to Paracoccidioides brasiliensis infection. Mycopathologia, v. 165, p. 223-236, 2008.

Artigo 4 CALICH, V.L.G.; PINA, A.; FELONATO, M.; BERNARDINO, S.; COSTA, T.A.; LOURES, F.V. Toll-like receptors and fungal infections: the role of TLR2, TLR4 and MyD88 in paracoccidioidomycosis. FEMS Immunol. Med. Microbiol., v. 53, p. 1-7, 2008. 